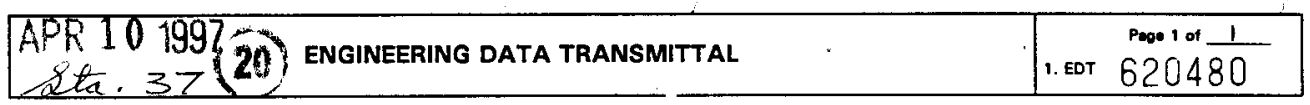

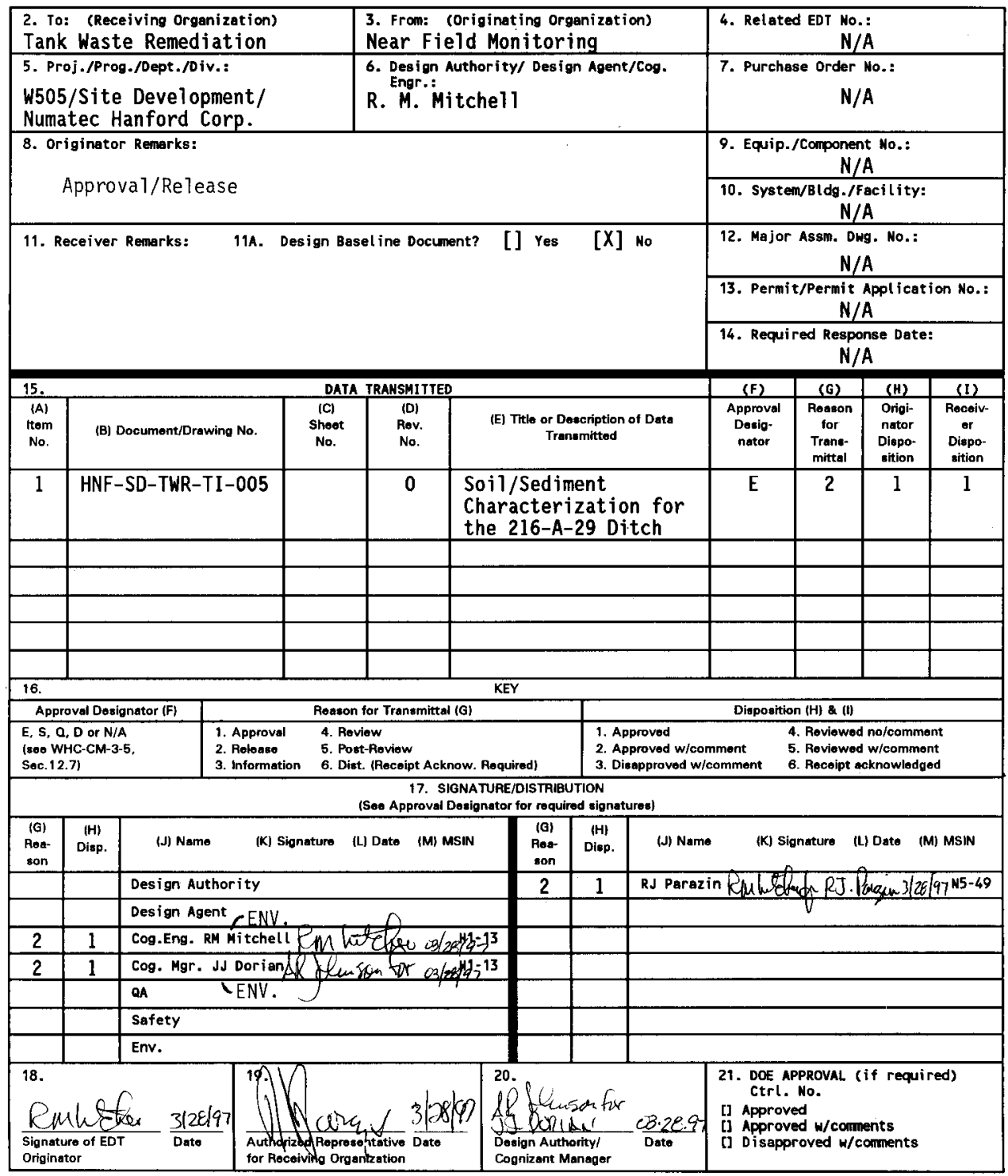




\section{Soil/Sediment Characterization for the 216-A-29 Ditch}

R. M. Mitchell

Rust Federal Services Inc. Northwest Operations

Richland, WA 99352

U.S. Department of Energy Contract DE-AC06-96RL13200

EDT/ECN: $\quad 620480$

UC: 2070

Org Code: 03E00

Charge Code: E21430

B\&R Code: EW3130010 Total Pages: $-117_{-8} 129$

Key Words: Soil, Sediment, Characterization, Samples, 216-A-29 Ditch, Environmental

Abstract: This document provides a detailed description of the environmental samples collected from the 216-A-29 Ditch in 1988. Tables summarizing the laboratory data for radionuclides, metals, and soil chemistry are included.

TRADEMARK DISCLAIMER. Reference herein to eny specific commercial product, process, or service by trade name, trademark, manufacturer, or otherwise, does not necessarily constitute or imply its endorsement, recommendation, or favoring by the United States Government or any agency thereof or its contractors or subcontractors.

Printed in the United States of Americs. To obtain copies of this document, contact: Document Control Services, P.O. Box 950, Mailstop H6-08, Richland WA 99352, Phone (50́9) 372-2420; Fax (509) 376-4989.

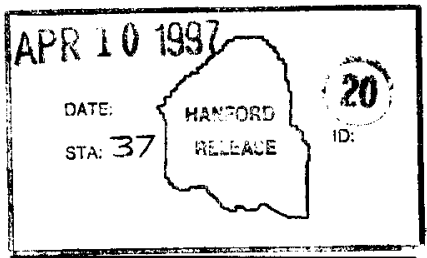




\section{Soil/Sediment Characterization for the 216-A-29 Ditch}

R. M. Mitchell

March 1997

Prepared for the U.S. Department of Energy

Assistant Secretary of Environmental Management

Rust Federal Services Inc.

Northwest Operations

P.O. Box 650

Richland, Washington 
HNF-SD-TWR-TI-005, Rev. 0

This page intentionally left blank. 


\section{TABLE OF CONTENTS}

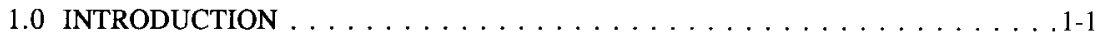

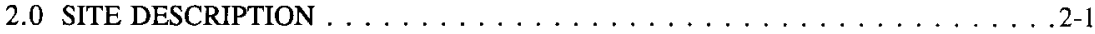

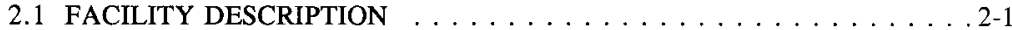

2.2 WASTE STREAM INFORMATION $\ldots \ldots \ldots \ldots \ldots \ldots \ldots \ldots .2-1$

2.3 HISTORICAL CHARACTERIZATION EFFORTS . . . . . . . . . . . 2-9

2.41988 SITE CONDITIONS $\ldots \ldots \ldots \ldots \ldots \ldots \ldots \ldots$

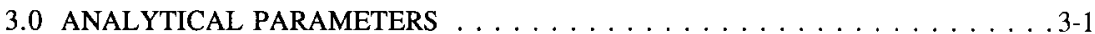

3.1 ANALYTICAL PROCEDURES . . . . . . . . . . . . . 3-1

3.2 ANALYTICAL METHODS $\ldots \ldots \ldots \ldots \ldots \ldots \ldots \ldots \ldots$

4.0 SAMPLING PROCEDURES FOR SOIL/SEDIMENT . . . . . . . . . . . . 4-1

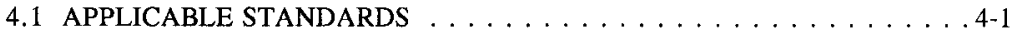

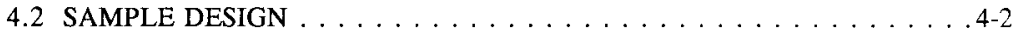

4.3 GUIDANCE DOCUMENTS . . . . . . . . . . . . . . . .4-3

4.4 SAMPLE LOCATIONS . . . . . . . . . . . . . . . . . 4-3

4.6 SAMPLE PLAN MODIFICATIONS . . . . . . . . . . . . . . 4-7

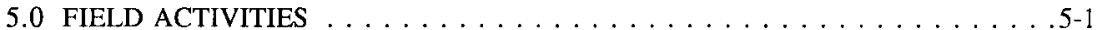

6.0 RESULTS AND DISCUSSION $\ldots \ldots \ldots \ldots \ldots \ldots \ldots \ldots \ldots \ldots \ldots \ldots \ldots$ 6-1

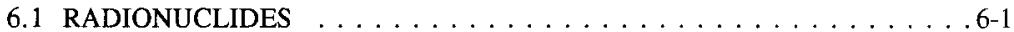

6.2 METALS . . . . . . . . . . . . . . . . . .6-1

6.3 OTHER ANALYTES $\ldots \ldots \ldots \ldots \ldots \ldots \ldots \ldots$. . . . . . . . . . . . . .

7.0 REFERENCES . . . . . . . . . . . . . . . . . . . . . . 7-1

\section{APPENDICES}

A DETAILED QUALITY ASSURANCE INFORMATION FOR ENVIRONMENTAL SAMPLES ANALYTICAL LABORATORY SERVICES PROVIDED BY UNITED STATES TESTING, INC.

B DETAILED SUMMARY OF THE DANGEROUS WASTE CONSTITUENTS IDENTIFIED IN WAC-173-303-9905 BY ANALYTICAL CATEGORY . . . . . . B-1

C LETTER REPORT ON RADIOLOGICAL SURVEY OF SEDIMENTS IN $216-A-29$ DITCH $\ldots \ldots \ldots \ldots \ldots \ldots \ldots \ldots$. . . . . . . . . . . . . . . .

D A-29 DITCH FIELD LOGBOOK . . . . . . . . . . . . D-1 


\section{LIST OF FIGURES}

1 Location of the A-29 Ditch in Relation to Other 200 East Area Facilities . . . . . . 2-2

2 Schematic Diagram of A-29 Ditch Effluent Sources . . . . . . . . . . . . 2-3

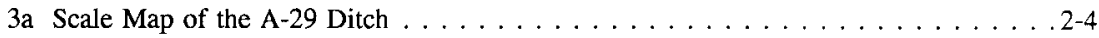

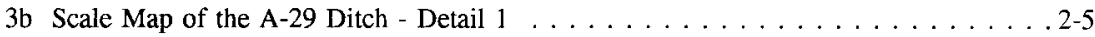

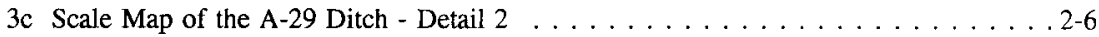

3d Scale Map of the A-29 Ditch - Detail $3 \ldots \ldots \ldots \ldots \ldots \ldots . \ldots \ldots$

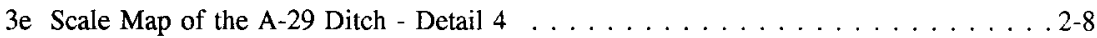

4 A-29 Ditch Sample Locations . . . . . . . . . . . . . . . . . . . . . . 5-2

\section{LIST OF TABLES}

1 216-A-29 Ditch Known and Potential Discharges . . . . . . . . . . . . 2-10

2 A-29 Ditch Preliminary Effluent Analytical Data . . . . . . . . . . . 2-11

3 Summary of Radionuclide Values for Grab Samples of Surface Sediments Collected from the A-29 Ditch. Data are from RHO Annual Environmental Surveillance Reports . . . . . . . . . . . . . . . . . . . . . . . 2-12

4 Summary of Radionuclide Values for Grab Samples of Aquatic Vegetation Collected from the A-29 Ditch. Data are from RHO Annual Environmental Surveillance Reports . . . . . . . . . . . . . . . . . . . . 2-13

5 Analytical Parameters for Selected Soils Samples from A-29 Ditch. . . . . . . . . . 3-2

6 Comparison of U.S. Environmental Protection Agency and U.S. Testing Methods

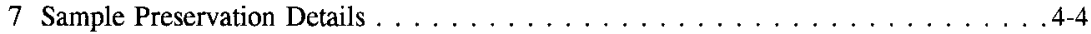

8 Sample Containers, Preservation Requirements, and Holding Times for Soil Samples 
HNF-SD-TWR-TI-005, Rev. 0

\section{LIST OF TABLES (Cont'd)}

9 Summary of Radionuclide Data for A-29 Ditch Sediments (pCi/g) . . . . . . 6-2

10 Summary of Radionuclide Data for A-29 Ditch Sediments $(\mathrm{pCi} / \mathrm{g}) \ldots \ldots$. . . . . 6-3

11 Summary of Metals Data for A-29 Ditch Sediments (ppm) . . . . . . . . . 6-4

11 Summary of Metals Data for A-29 Ditch Sediments $(\mathrm{ppm}) \ldots \ldots \ldots \ldots$ 6-5 $\ldots \ldots$

12 Comparison of Maximum Metals Values for Soils at Selected Sites (ppm) . . . . 6-6

13 Comparison of Maximum Metals Values for Soils at Selected Sites (ppm) . . . . 6-8

14 Summary of Chemical Data for A-29 Ditch Sediments (ppm) . . . . . . . . 6-9

15 Summary of Organic and Chemical Analytes for A-29 Ditch Sediments (ppm) . . 6-10 
HNF-SD-TWR-TI-005, Rev. 0

\section{ACRONYMS AND ABBREVIATIONS}

$\begin{array}{ll}\text { DQO } & \text { Data Quality Objectives } \\ \text { Ecology } & \text { Washington State Department of Ecology } \\ \text { EPA } & \text { U.S. Environmental Protection Agency } \\ \text { GC/MS } & \text { gas chromatograph/mass spectrometer } \\ \text { GM } & \text { Geiger-Mueller (detector tube) } \\ \text { ICP } & \text { inductively coupled argon plasma } \\ \text { MRAL I } & \text { Mobile Radionuclide Analysis Laboratory } \\ \text { OSHA } & \text { Occupational Safety and Health Administration } \\ \text { PCB } & \text { polychlorinated biphenyl } \\ \text { PUREX } & \text { Plutonium Uranium Extraction (Facility) } \\ \text { RCRA } & \text { Resource Conservation and Recovery Act of } 1976 \\ \text { RPT } & \text { Radiation Protection Technician } \\ \text { TOC } & \text { total organic carbon } \\ \text { TWRS } & \text { Tank Waste Remediation System } \\ \text { UST } & \text { U.S. Testing, Inc. } \\ \text { WAC } & \text { Washington Administrative Code }\end{array}$




\subsection{INTRODUCTION}

In 1987, an effort was initiated to develop a detailed site characterization plan as per the commitment in the Preliminary Closure/Post Closure Plan for the 216-A-29 Ditch submitted to the Washington State Department of Ecology (Ecology) in April 1987. This characterization effort is described in detail in this document.

In 1987 and 1988, development of sampling methodologies, characterization plans, and analytical protocols in support of the Resource Conservation and Recovery Act of 1976 (RCRA) regulatory efforts were in the initial stages at the Hanford Site. The first site characterization plans developed were for the 2101-M Pond and the A-29 Ditch. The field methodologies, sample protocols, and analytical support (provided by U.S. Testing, Inc. [UST]) was the same at both sites. The 2101-M Pond Closure Plan (DOE-RL 1989) was developed in concert with Ecology and the U.S. Environmental Protection Agency (EPA) regulators. These efforts eventually led to the clean closure of 2101-M Pond in 1995. However, reductions in funding led to a decision to provide other engineering alternatives for the A-29 Ditch. The sample data and analytical reports which had been developed from soil/sediment sampling at the A-29 Ditch were archived and no report was issued at that time.

The implementation of the Tank Waste Remediation System (TWRS) Phase 1 Privatization Project has necessitated the development of a site improvements corridor that would cross the retired A-29 Ditch. In support of that effort, the archived data was recovered and this document prepared. The primary purposes of this report are to:

- Provide a summary of the radiological, chemical, and organic analyses from that sampling

- Provide a historical perspective for how the project was designed and conducted in 1988

- Provide a detailed description of the A-29 Ditch as it existed in 1988

- Describe the 1988 field sampling effort

- Document the UST analytical procedures and protocols

- Provide some perspective on the 1988 data with regard to current environmental circumstances.

All of this taken together can be utilized to assist in the development of Data Quality Objectives (DQO) in support of the proposed development for the Phase 1 Privatization Project. 
HNF-SD-TWR-TI-005, Rev. 0

This page intentionally left blank. 
HNF-SD-TWR-TI-005, Rev. 0

\subsection{SITE DESCRIPTION}

The 216-A-29 Ditch no longer exists in the configuration it exhibited during the 1988 sampling effort. Therefore, a detailed description of the ditch as it existed in 1988 is necessary in order to ascertain why, how, and where the ditch was sampled.

The 216-A-29 Ditch (hereafter referred to as the A-29 Ditch) is located east of the 200 East perimeter, outside of the security-fenced area. The open, head-end of the ditch was located approximately $300 \mathrm{~m}(900 \mathrm{ft})$ east of the 200 East fence. It then flowed in a

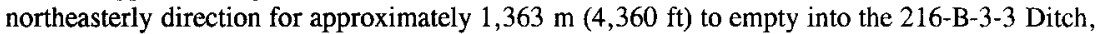
which flowed into the 216-B-3 Pond (Figure 1). Open expanses of land dominated by relatively undisturbed expanses of sagebrush and cheatgrass were located on the eastern and western borders of the ditch. Although the majority of the ditch length was located outside 200 East security fence, it was still within the restricted portion of the Hanford site. Direct access to the ditch was restricted to site personnel, since it was "posted" as a low-level radioactive waste site. The posting required that a Radiation Protection Technician (RPT) be present for admittance to the site.

\subsection{FACILITY DESCRIPTION}

The A-29 Ditch was a man-made, unlined earthen ditch that was approximately $1,683 \mathrm{~m}$ $(5,385 \mathrm{ft})$ long (total for piped and open sections) and had been in use since 1955. All discharge to the ditch occurred within the 200 East Area perimeter fence. The discharge point from the Plutonium Uranium Extraction (PUREX) chemical sewer line was located at the northeast corner of the AP Tank Farm (Figure 2). The line fed through a diversion box in a $38 \mathrm{~cm}(15$ in.) vitrified clay pipe and into a $91 \mathrm{~cm}(36 \mathrm{in}$.) corrugated metal pipe $7.6 \mathrm{~m}(25 \mathrm{ft})$ long. It then discharged to the open ditch along a $3 \mathrm{~m}(10 \mathrm{ft})$ of concrete spillway.

The wetted portion of the ditch varied from about $0.6-\mathrm{m}(2-\mathrm{ft})$ wide at the head-end to approximately $1.2-\mathrm{m}(4-\mathrm{ft}$ ) wide at its mouth (Figure 3 ). The water depth varied from about $0.6 \mathrm{~m}(2 \mathrm{ft})$ at the head-end to $10 \mathrm{~cm}(4 \mathrm{in}$.) at the confluence with the 216-B-3-3 Ditch. The height and width of the banks varied greatly along the length of the ditch. The banks were about $1-\mathrm{m}(3-\mathrm{ft})$ high at the lower end. The width of the ditch varied from $1.2 \mathrm{~m}(4 \mathrm{ft})$ at the ditch head to over $15.3-\mathrm{m}(50-\mathrm{ft})$ wide at the lower end. Figure 3 provides an indication of the variability in the ditch dimensions as the water moved downstream.

\subsection{WASTE STREAM INFORMATION}

The A-29 Ditch received liquid waste from the PUREX Plant and directed it into the 216-B-3 Pond. Flow rates varied from 378 to $5,290 \mathrm{~L} / \mathrm{min}(100$ to $1,400 \mathrm{gal} / \mathrm{min})$, with an average flow of $3,760 \mathrm{~L} / \mathrm{min}(970 \mathrm{gal} / \mathrm{min})$. 


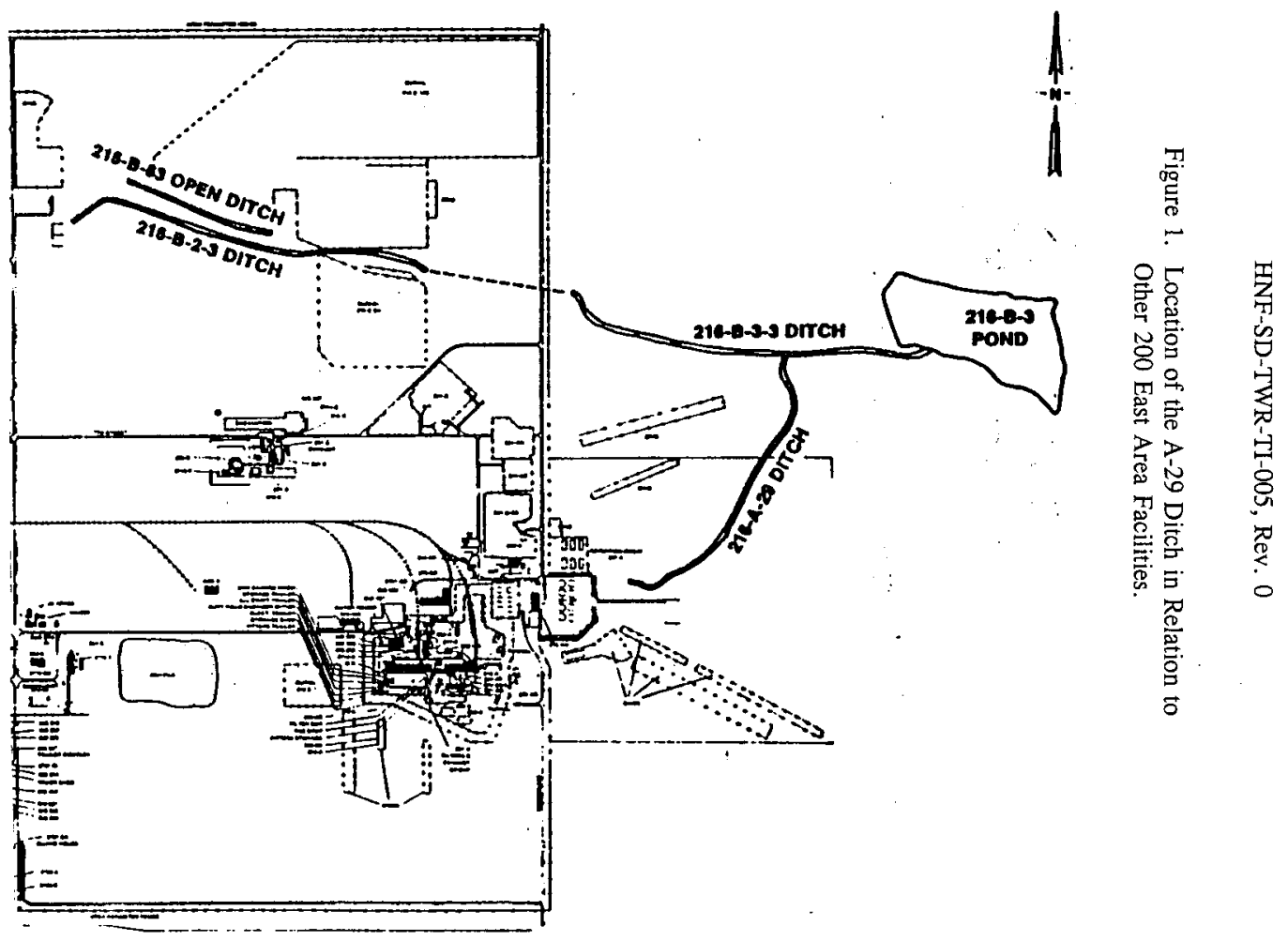




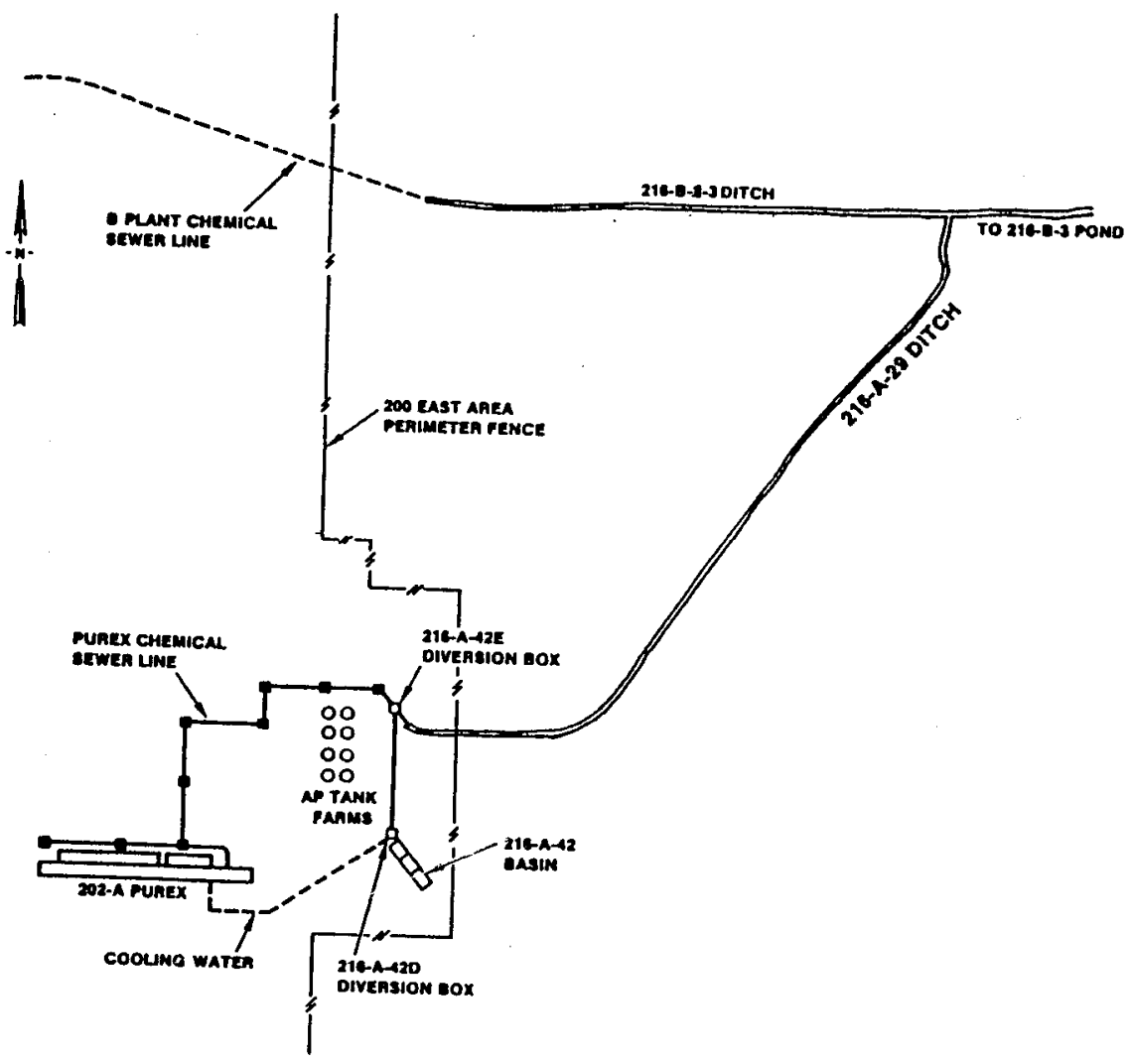


Figure 3a. Scale Map of the A-29 Ditch.

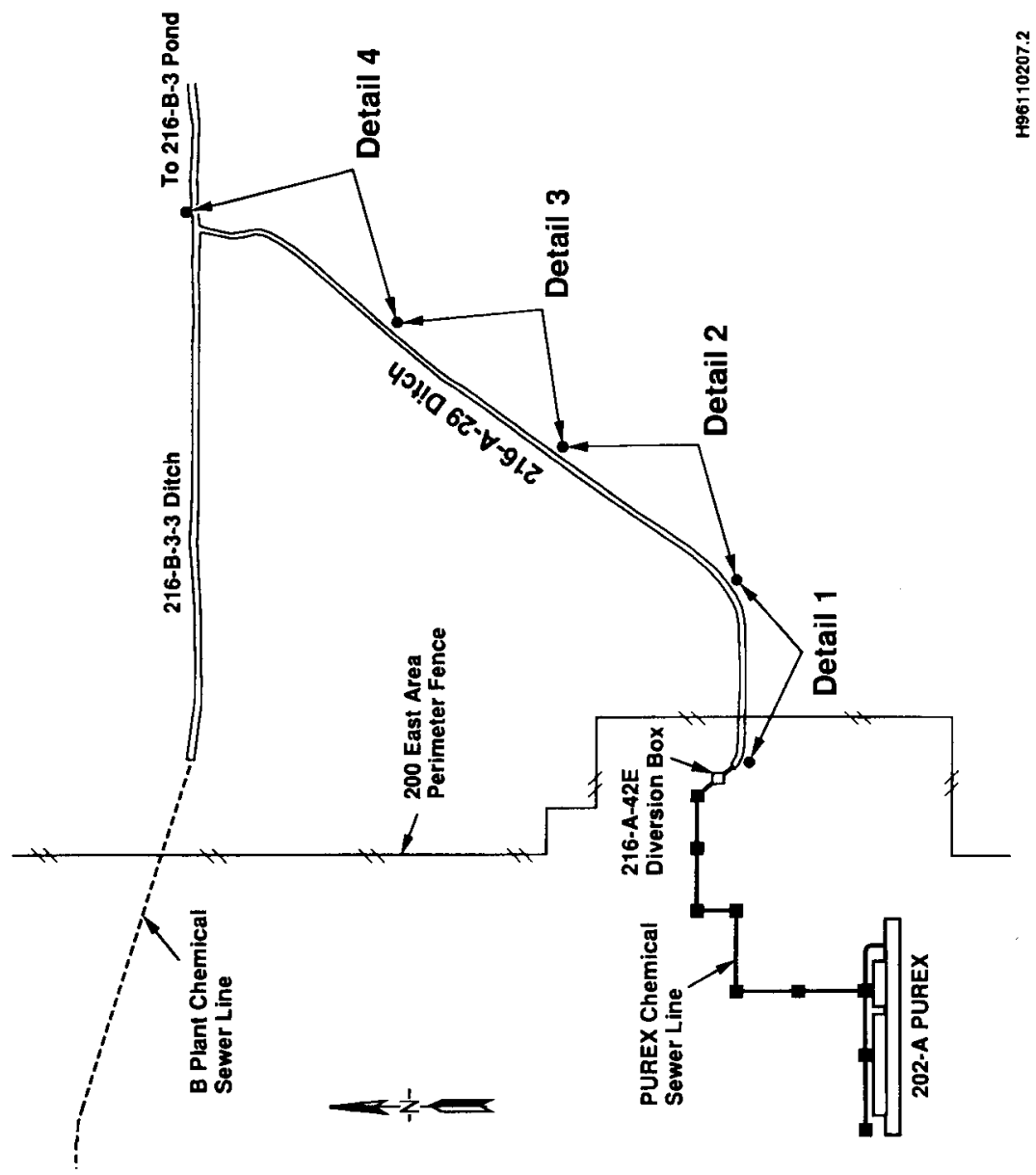


Figure 3b. Scale Map of the A-29 Ditch - Detail 1.
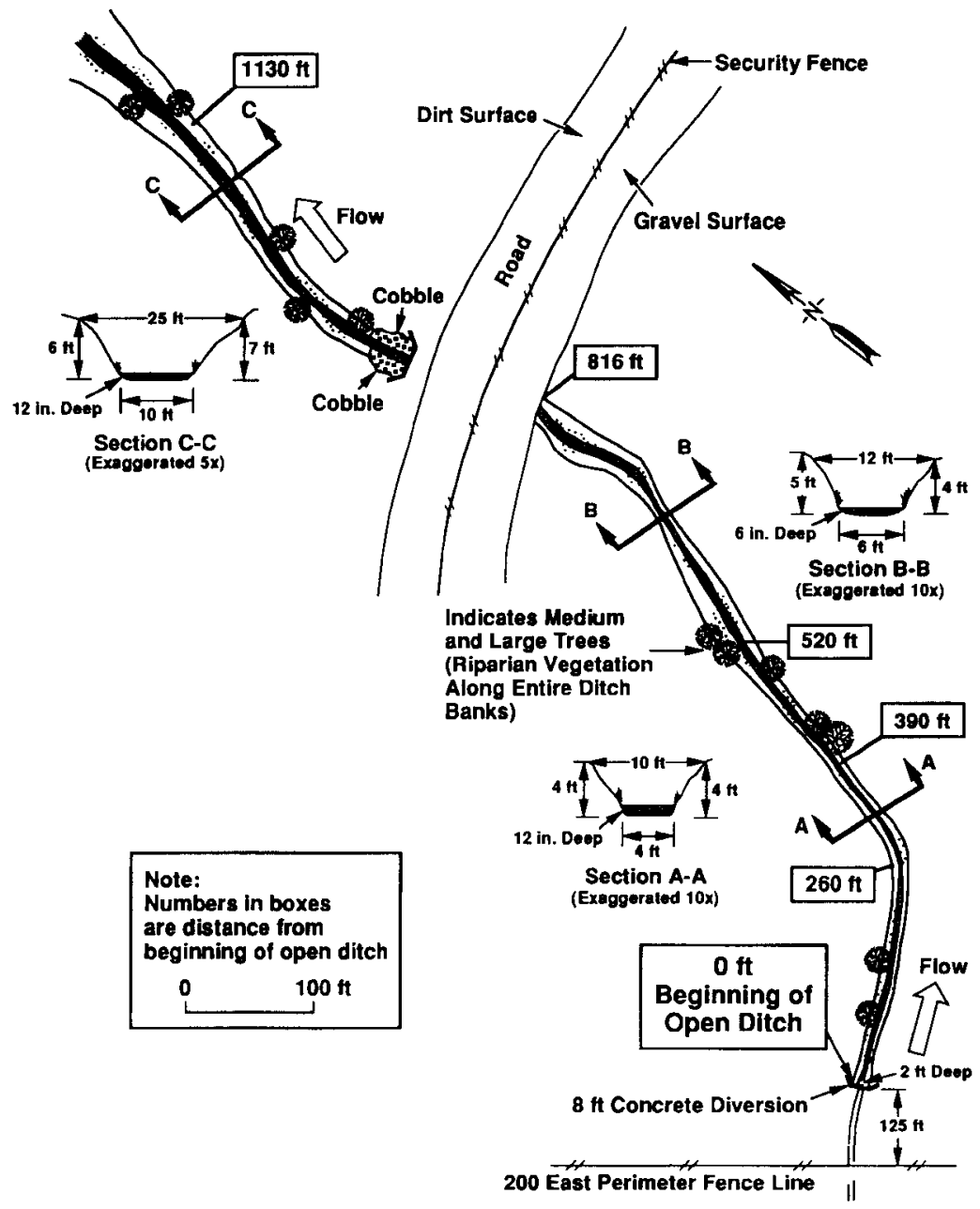

H96110207.3 
HNF-SD-TWR-TI-005, Rev, 0

Figure 3c. Scale Map of the A-29 Ditch - Detail 2.

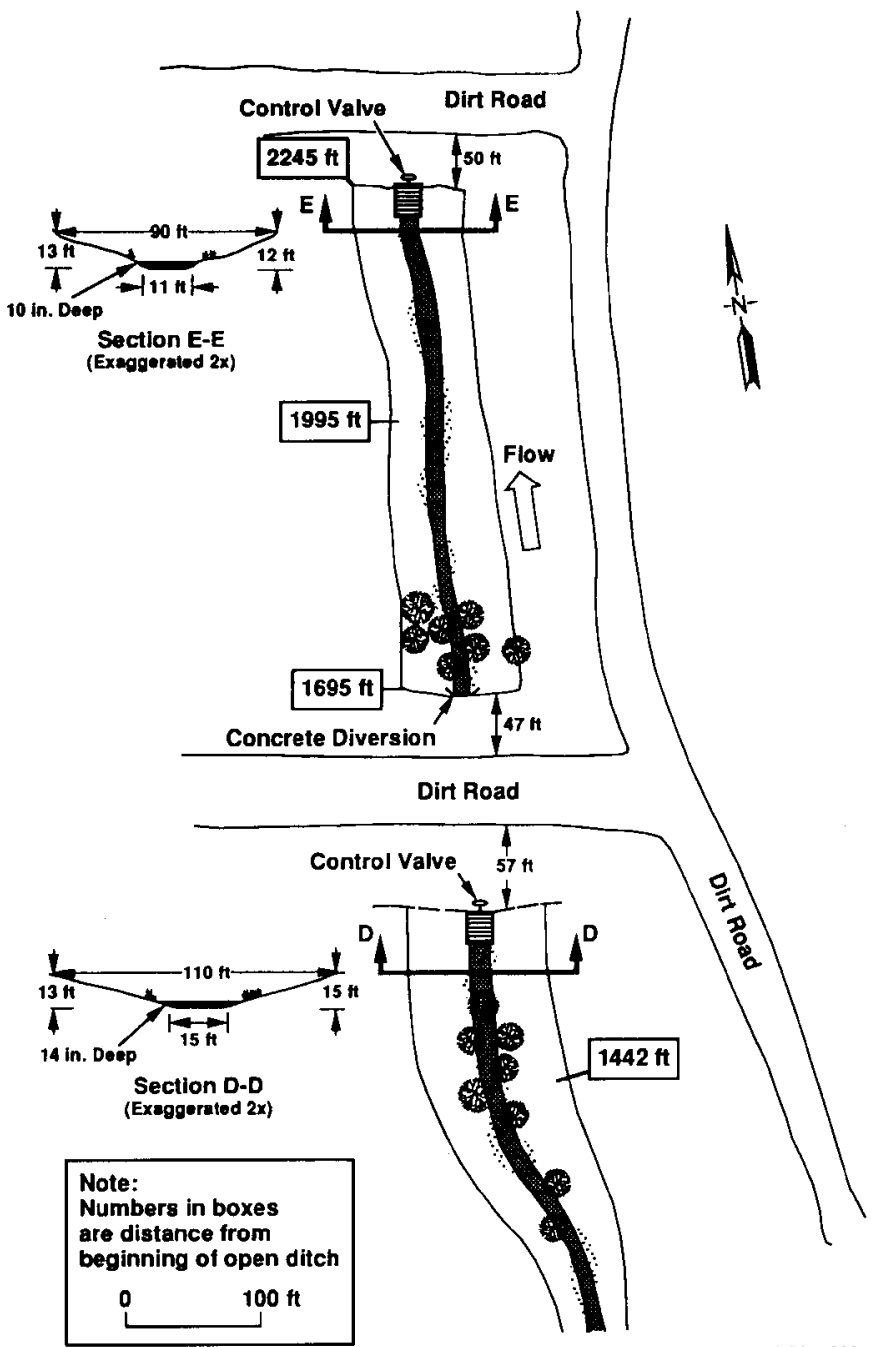

H96110207.4 
HNF-SD-TWR-TI-005, Rev. 0

Figure 3d. Scale Map of the A-29 Ditch - Detail 3.

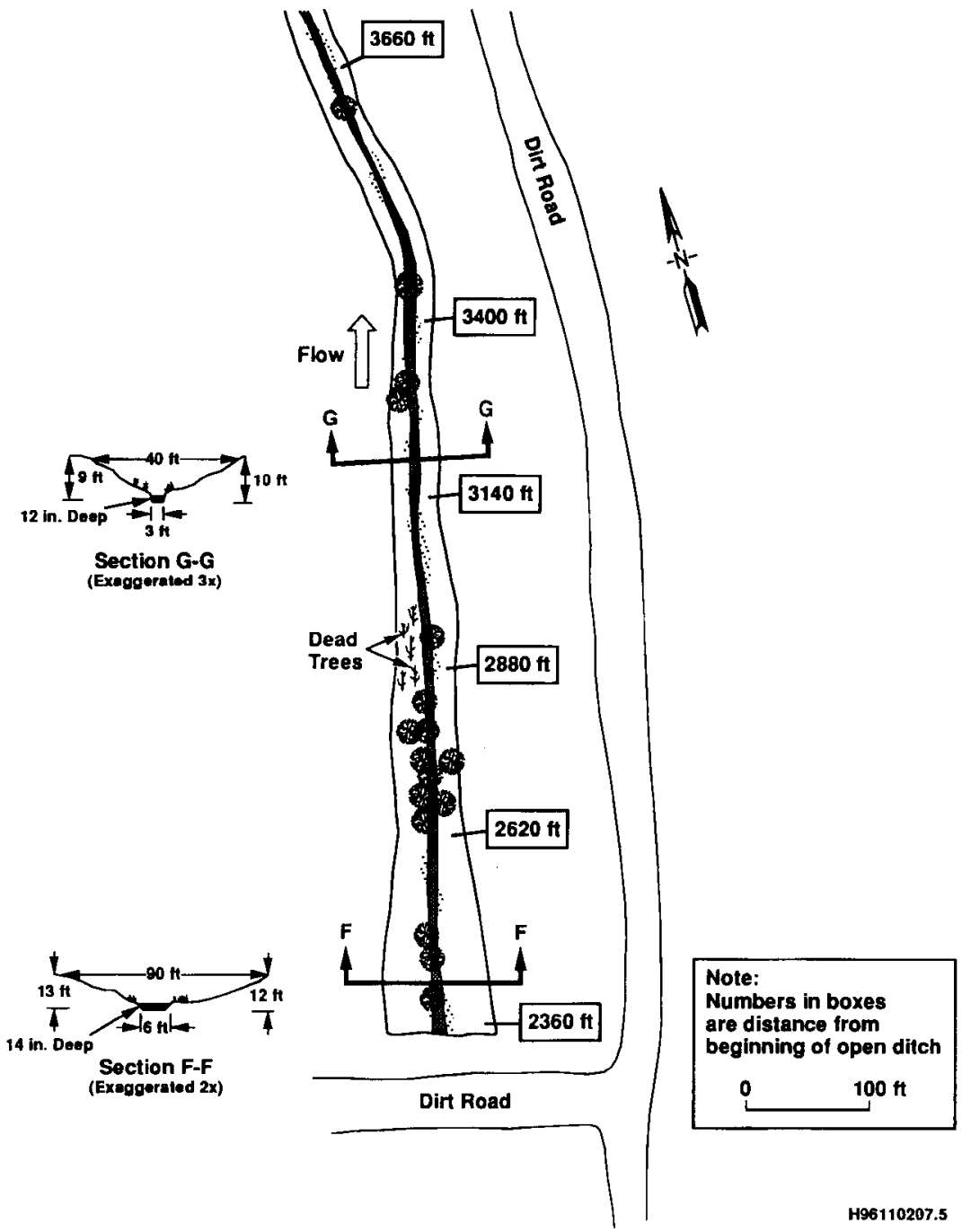


Figure 3e. Scale Map of the A-29 Ditch - Detail 4.

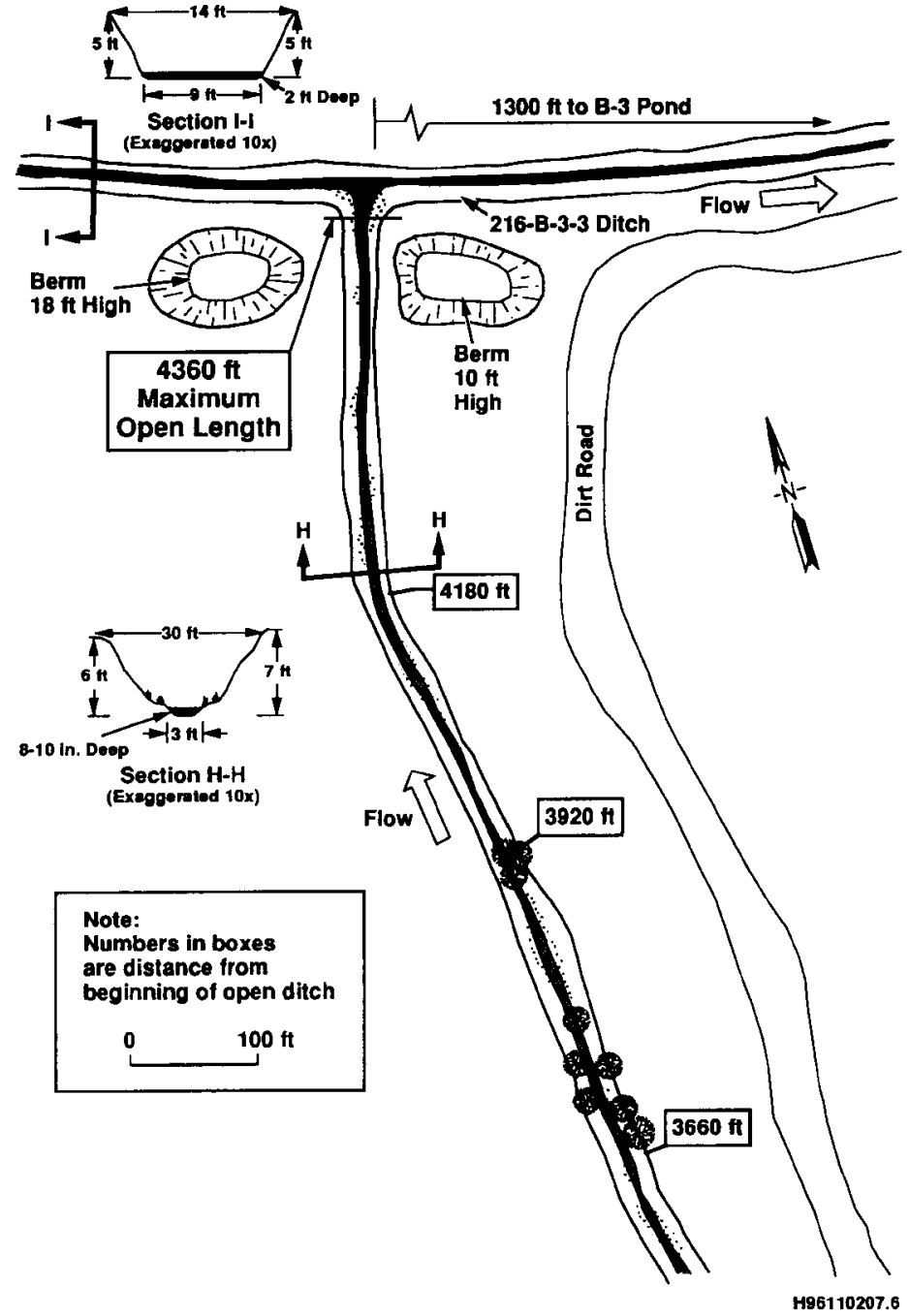


Prior to introduction of administrative controls to eliminate hazardous waste discharges, the A-29 Ditch received intermittent batches of spilled materials and/or off-specification chemicals. Additionally, routine corrosive effluent was discharged from the plant demineralizer regeneration system. Table 1 provides a summary of known and potential discharges to the ditch. The discharges of sodium hydroxide and sulfuric acid solutions from demineralizer operations occurred on a daily basis until February 1986.

The A-29 Ditch effluent had been sampled and analyzed for hazardous constituents. Data for 1985 through 1987 effluent sample periods are summarized in Table 2 . The effluent did contain low-level radioactivity. These data indicated that this effluent was not a dangerous waste as defined in Washington Administrative Code (WAC) 173-303 (Ecology 1986).

\subsection{HISTORICAL CHARACTERIZATION EFFORTS}

A-29 Ditch had been a focus for routine sampling since 1976, to support the annual environmental surveillance reports for the 200 Areas radioactive waste sites. The values summarized in Tables 3 and 4 represent grab samples for ditch sediments and vegetation (not species specific) collected on an annual basis from the head-end of the ditch (Figure 3). Values ranged from less than detection limits to a high value of $127 \mathrm{pCi} / \mathrm{gm}$ in sediments for cesium-137. All of these values, with the exception of the 1984 value reported for $\mathrm{Pu}-239 / 240$ in vegetation, were well below 200 Area soil standards (Boothe 1985).

In 1982, a radiological survey was conducted on the upper end of the A-29 Ditch in order to estimate the extent of contamination for removal prior to construction activities in the area. Sediment samples were collected from 5 shallow hand-cored ditch bottom borings to a depth of 0.9 to $1.2 \mathrm{~m} \mathrm{(} 3$ to $4 \mathrm{ft}$ ) and auger borings along the ditch banks drilled to a depth of $3.7 \mathrm{~m}$ (12 ft). Radionuclides were analyzed utilizing the Mobile Radionuclide Analysis Laboratory (MRAL I). Radionuclide concentrations (gamma emitters) were determined to be at background levels, with the exception of cesium-137. The highest value for cesium-137 was found in the top (uppermost) sample from the ditch core samples; with a maximum observed value of $90 \mathrm{pCi} / \mathrm{gm}$. The report in its entirety is included in Appendix C.

\subsection{SITE CONDITIONS}

The riparian habitat which surrounded the A-29 Ditch was generaliy typical of the wetland communities created by man in the arid conditions of the shrub-steppe desert. The area immediately adjacent to the ditch was relatively undisturbed habitat consisting of sagebrush, cheatgrass, rabbitbrush, and various native grass species. Since the characterization efforts previously discussed were conducted, a number of projects had impacted the first $366 \mathrm{~m}$ $(1,200 \mathrm{ft})$ of the open A-29 Ditch. A portion of this area was widened and the ditchbank removed to reduce contamination during construction of the 241-AP Tank Farm. The PUREX 
HNF-SD-TWR-TI-005, Rev. 0

Table 1.

Table 1. 216-A-29 Ditch Known and Potent1al Discharges:

\begin{tabular}{|c|c|c|}
\hline Waste & Date & Description \\
\hline Demineralizer regenerant & 1955 to February 1986 & $\begin{array}{l}\text { Characteristic } \\
\text { (corrosive) }\end{array}$ \\
\hline $\begin{array}{l}\text { Aqueous makeup tank heels and } \\
\text { offi-specification batches }\end{array}$ & 1955 to October 1984 & $\begin{array}{l}\text { Characteristic } \\
\text { (corrosive and EPa toxic) }\end{array}$ \\
\hline $\begin{array}{l}\text { N Cell prestart testing } \\
\text { (oxalic acid, nitric acid, hydrogen } \\
\text { peroxide, calcium nitrate) }\end{array}$ & $\begin{array}{l}\text { April } 11,1983 \text { to } \\
\text { August } 7,1983\end{array}$ & $\begin{array}{l}\text { Characteristic } \\
\text { (corrosive) }\end{array}$ \\
\hline $\begin{array}{l}\text { Potassium permanganate, } \\
\text { sodium carbonate solution }\end{array}$ & October 19, 1983 & $\begin{array}{l}\text { CERCLAb-reportable } \\
\text { release }\end{array}$ \\
\hline Hydrazine HN solution & $\begin{array}{l}\text { June } 6,1984 \\
\text { September } 13,1984 \\
\text { October } 2,1984\end{array}$ & $\begin{array}{l}\text { CERCLA-reportable } \\
\text { release }\end{array}$ \\
\hline Potassium hydroxide & December 2, 1984 & $\begin{array}{l}\text { CERCLA-reportable } \\
\text { release }\end{array}$ \\
\hline Sodium nitrate & February 8,1985 & $\begin{array}{l}\text { CERCLA-reportable } \\
\text { release }\end{array}$ \\
\hline Nitric acid & $\begin{array}{l}\text { August } 22,1984 \\
\text { January } 18,1985 \\
\text { May } 27,1985 \\
\text { June } 25,1985 \\
\text { October } 28,1985\end{array}$ & $\begin{array}{l}\text { CERCLA-reportable } \\
\text { release }\end{array}$ \\
\hline Sodium hydroxide & $\begin{array}{l}\text { February 26, } 1984 \\
\text { November } 19,1984 \\
\text { August } 6,1985\end{array}$ & $\begin{array}{l}\text { CERCLA-reportable } \\
\text { release }\end{array}$ \\
\hline Cadmium nitrate & $\begin{array}{l}\text { May 16, } 1984 \\
\text { Desember } 18,1985\end{array}$ & $\begin{array}{l}\text { CERCLA-reportable } \\
\text { release }\end{array}$ \\
\hline Hydrazine & Suly 9, 1986 & $\begin{array}{l}\text { CERCLA-reportable } \\
\text { release }\end{array}$ \\
\hline
\end{tabular}

-Extraction procedure.

bComprehensive Environmental Response, Compensation, and Liability ACR. 
Table 2. A-29 Ditch Preliminary Effluent Analytical Data

Sample

Sampling Date

US Testing Number

Stream Fraction

\section{Aluminum \\ Anmorium \\ Antimony \\ Earium \\ Eerylizium \\ Cadmium \\ Calcium \\ Chromium \\ Copper \\ Iron \\ Lead \\ Magnesium \\ Manganese \\ Mercury \\ Nickel \\ Fotassium \\ Silver \\ Sodium \\ Strontium \\ Tin}

Uranium

Vanadium

Zine

Chloride

Cyanide

Fluoride

Nitrate

Fhosphate

Sulfate

Acetone

Disobutyl phthalate

pH (dimensionless)

Temperature (celsius)

Alpha Activity ( $\mathrm{PCi} / \mathrm{L}$ )

Eeta Activity ( $\mathrm{pCi} / L$ )

Conductivity (uS/cm)

Total Drganic Carbon (ppl)

Total Organic Halide (pob)

Sultide

\begin{tabular}{|c|c|c|c|c|}
\hline $\begin{array}{c}15 t \\
08 / 22 / 85 \\
50002 \\
1.0 E+00\end{array}$ & $\begin{array}{c}\text { 2nd } \\
06 / 06 / 86 \\
50054 \\
1.0 \mathrm{E}+00\end{array}$ & $\begin{array}{c}\text { srd } \\
12 / 19 / 86 \\
50204 \\
1.0 E+00\end{array}$ & $\begin{array}{c}4 \text { th } \\
03 / 18 / 87 \\
50260 \\
1.0 E+00\end{array}$ & $\begin{array}{c}5 \text { th } \\
04 / 06 / 87 \\
50273 \\
1.0 \mathrm{0}+00\end{array}$ \\
\hline & & 1. $5 E+02$ & $<1.5 E+62$ & $E+02$ \\
\hline & $<5.0 E+01$ & 1. 2E+02 & $\angle 5.0 E+01$ & \\
\hline $1.0 E+02$ & (1. OE + OQ & $\checkmark 1.0 E+02$ & $\langle 1.0 E+02$ & $\angle 1 . O E+O Z$ \\
\hline $3.4 E+01$ & $2.4 E+61$ & $\Xi .1 E+01$ & $2.6 E+01$ & 2. $4 E+01$ \\
\hline K5. OEE+00 & $\angle 5.0 E+00$ & $<5.0 E+00$ & $\angle 5.0 E+00$ & $\langle 5.0 E+00$ \\
\hline $7.0 E+400$ & $<2.0 E+00$ & $<2.0 E+00$ & $<2.0 E+00$ & $\angle 2.0 E+00$ \\
\hline 1. $9 \mathrm{EHO} 4$ & 1. $4 E+04$ & 2. OE+04 & $2.1 E+04$ & $2.0 E+04$ \\
\hline 1. $4 E+01$ & $\therefore 1.0 E+01$ & $<1.0 E+01$ & $\therefore 1.0 E+01$ & $<1.0 E+0.1$ \\
\hline $8.0 E+01$ & $1.0 \mathrm{E}+01$ & $2.8 E+01$ & $\angle 1.0 E+01$ & $\therefore 1.0 E+1\rangle 1$ \\
\hline $65.0 E+1) 1$ & $2.2 E+02$ & S. OE+O1 & 6. $\Xi E+01$ & $6.0 E+11$ \\
\hline$\angle B-O E+01$ & & ४5. OE +00 & $<5.0 E+00$ & \\
\hline $3.5 E+03$ & $3.2 E+0.3$ & $4.7 E+0$. & 4.7E+03 & 4. $2 E+0=$ \\
\hline $1.0 E+01$ & $1.3 E+01$ & $<1 . O E-O 1$ & $5.0 E+00$ & $65.0 E+r)$ \\
\hline$\angle 1.0 E-01$ & $<1.0 E-01$ & $41.0 E-01$ & 1. $5 E-01$ & \\
\hline $1.6 E+01$ & $\therefore 1 . \mathrm{OE}+01$ & $\therefore 1.0 E+01$ & $<1.0 E+01$ & $81.0 E+01$ \\
\hline $6.1 E+02$ & $1.3 E+0.3$ & $8.2 E+62$ & 8. $4 E+02$ & $7.4 E+0=$ \\
\hline$\therefore 1.0 E+01$ & $\langle 1.0 E+01$ & $\langle 1.0 E+01$ & $\angle 1.0 E+01$ & $<1.0 E+c .1$ \\
\hline $3.1 E+0 \Xi$ & 2. $6 E+03$ & 1. $2 E+04$ & $3.2 E+05$ & $2.0 E+i z$ \\
\hline$\angle 3.0 E+02$ & $<\bar{B} \cdot O E+02$ & $\angle 3.0 E+02$ & $\therefore$ O OE+0Z & $\angle B .0 E+62$ \\
\hline \multicolumn{5}{|l|}{$\therefore 3.0 E+0 Z$} \\
\hline 4. $8 E-01$ & $4.1 E-01$ & $4.2 E-01$ & $4.2 E-01$ & \\
\hline $6.0 E+00$ & $\therefore 5.0 E+00$ & $\angle 5.0 E+00$ & $<5.0 E+00$ & $\angle 5.0 E+\%$ \\
\hline $4.7 E+01$ & $5.0 E+00$ & $1.0 E+01$ & 1. $3 E+61$ & $7.0 \mathrm{E}+0 \mathrm{O}$ \\
\hline 1. $2 E+0.3$ & $<5.0 E+0 ?$ & $1.0 E+0.5$ & 1. $2 E+0 \overline{5}$ & 1. $2 E+0 Z$ \\
\hline $1.0 E+01$ & $\langle 1.0 E+01$ & $\angle 1 . O E+01$ & $<1.0 E+01$ & $\angle 1.0 E+01$ \\
\hline$=.8 E+02$ & $\checkmark 5.0 E+02$ & $\therefore 5.0 E+02$ & $\angle 5.0 E+02$ & $\div 5.0 E+0 Z$ \\
\hline B. $4 E+02$ & $\langle 5.0 E+02$ & $5.4 E+02$ & $5.8 E+62$ & $<5.0 E+02$ \\
\hline$\angle 1.0 E+03$ & $<1.0 E+03$ & $\therefore 1.0 \mathrm{OE}+0 \mathrm{Z}$ & $\angle 1.0 E+0$. & $1.0 E+0 z$ \\
\hline $1.0 E+04$ & $8.0 E+15$ & 1.2E+04 & $1.3 E+04$ & $1.1 E+04$ \\
\hline $6.7 E+01$ & & & & $2.0 E+62$ \\
\hline \multicolumn{5}{|l|}{$2.0 E+01$} \\
\hline $8.1 \mathrm{E}+00$ & $7.7 E+00$ & 8.56 & 7.12 & 8.52 \\
\hline 3. $3 E+01$ & $\Xi .1 E+01$ & 1. $6 E+01$ & $1.3 E+01$ & $2.5 E+01$ \\
\hline $4.9 E-02$ & $4.0 E+00$ & $6.0 E-01$ & ¿1.8E-01 & $44.2 E-11$ \\
\hline$\therefore .2 E+00$ & $2.3 E+01$ & $\Xi .8 E+00$ & 4. . $9 E+00$ & $5.1 E+0$ \\
\hline 1. $4 E+U 2$ & 1. $\Xi E+01$ & 1. $7 E+02$ & 1. $1 E+02$ & 1. $5 E+02$ \\
\hline 1. $2 E+0.3$ & $2.5 E+05$ & 1. . $3 E+0$. & $1.2 E+03$ & 1.SE+0E \\
\hline (1. $0 E+02$ & 2.7E+01 & S. $1 E+01$ & $2.8 E+01$ & \\
\hline$\because 1.0 E+0.5$ & 1. $3 E+03$ & HTE & $<1.0 E+0$. & \\
\hline
\end{tabular}

Legend: Analyte concentrations are in ppb. Fiesult notations include data that were not recorded (NF) and measurements by methods that were not ir control (NIC) at the time of the measurement and measurements made atter holdino times wora exceeded (HTE). 
HNF-SD-TWR-TI-005, Rev. 0

Table 3. Summary of Radionucl ide Values for Grab Samples of Surface Sediments Collected from the A-29 Ditch. Data are from RHO Annual Environmental Surveillance Reports.

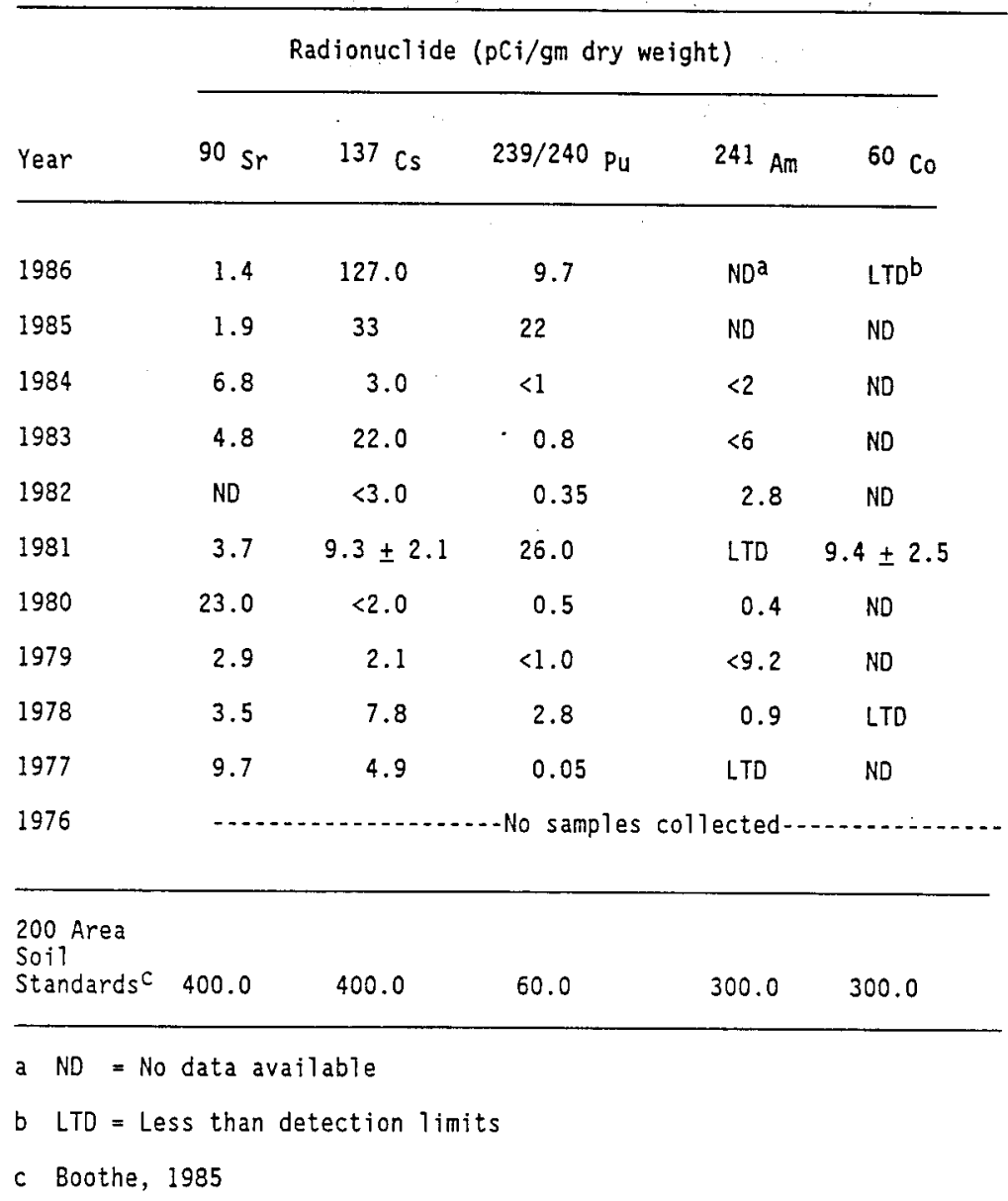


HNF-SD-TWR-TI-005, Rev. 0

Table 4. Summary of Radionuclide Values for Grab Samples of Aquatic Vegetation Collected from the A-29 Ditch. Data from RHO Annual Environmental Surveillance Reports.

\begin{tabular}{|c|c|c|c|c|c|}
\hline \multirow[b]{2}{*}{ Year } & \multicolumn{4}{|c|}{ Radionuclide (oCi/gm dry weight) } & \multirow[b]{2}{*}{$60 \mathrm{Co}$} \\
\hline & $90 \mathrm{sr}$ & 137 Cs & $239 / 240 \mathrm{Pu}$ & $241 \mathrm{Am}$ & \\
\hline 1986 & 3.5 & $<1$ & 0.2 & $N D^{a}$ & ND \\
\hline 1985 & $<1$ & $<1$ & $<1$ & ND & ND \\
\hline 1984 & 4.1 & 91 & 98 & $<5$ & $L T D^{b}$ \\
\hline 1983 & 0.5 & 15.0 & 19.0 & $<9.0$ & LTD \\
\hline 1982 & 0.8 & $27.4 \pm 0.9$ & 23.0 & 2.6 & LTD \\
\hline 1981 & 1.4 & $9.2 \pm 0.5$ & 1.5 & LTD & LTD \\
\hline 1980 & $<1$ & 4.7 & 3.2 & 9.9 & LTD \\
\hline 1979 & 45.1 & 8.6 & 14.4 & $<8.4$ & LTD \\
\hline 1978 & 0.7 & 8.1 & 18.2 & 4.8 & LTD \\
\hline 1977 & 0.54 & 2.4 & LTD & 13.6 & LTD \\
\hline 1976 & LTD & 8 & 15 & 10 & LTD \\
\hline $\begin{array}{l}200 \text { Area } \\
\text { Soi } 1 \\
\text { Standards }\end{array}$ & 400.0 & 400.0 & 60.0 & 300.0 & 300.0 \\
\hline
\end{tabular}
a $N D=$ No data available
b $L T D=$ Less than detection limits
c Boothe, 1985 
Plant had subsequently restarted increasing the flow rate through the ditch. Development of the Grout Facility had resulted in construction activities near the upper end of the ditch, including new roads and the fences indicated in Figure 3.

The flow rate of water in the ditch was moderate at approximately $3,780 \mathrm{~L} / \mathrm{min}$ $(1,000 \mathrm{gal} / \mathrm{min})$ and the depth of water varied from about $0.6 \mathrm{~m} \mathrm{(2 \textrm {ft } )}$ to $10 \mathrm{~cm}(4 \mathrm{in}$.$) . Areas$ of open water were limited and mostly located in the rechanneled, upper portion of the ditch. the remainder of the wetted portion of the ditch was overgrown with cattails, bulrushes, sedges, horsetail, speedwell, smartweed, and wild lettuce. Trees varying from 1.2 to $9.2 \mathrm{~m} \mathrm{(4} \mathrm{to} 30 \mathrm{ft}$ ) in height were comprised primarily of peachleaf willow, sandbar willow, black cottonwood, and an occasional mulberry and dominated the ditch along its entire length (Figure 3).

The depth to groundwater was estimated to be approximately $82 \mathrm{~m}(270 \mathrm{ft})$ at the headend and $52 \mathrm{~m}(170 \mathrm{ft})$ at the point the ditch emptied into the 216-B-3-3 Ditch.

Following the development of an engineering alternative for the rerouting of A-29 Ditch effluents to B-Pond, the A-29 Ditch was retired and covered with backfill soil in 1991/1992 (Smith 1992) 


\subsection{ANALYTICAL PARAMETERS}

The UST company served as the Hanford Site contractor for analyses of environmental samples collected on site in 1988. All samples collected were preserved as per the applicable procedures and shipped to the UST Facility in Richland, Washington.

The parameters sampled for in soils and sediments collected at the A-29 Ditch were determined based on the following:

- General lack of information on hazardous waste constituents in effluents prior to 1983

- $\quad$ Reported releases of acids and bases

- Reported releases of calcium, nitrate, potassium permanganate, hydrazine, sodium nitrate, and cadmium nitrate.

Therefore, the samples from the A-29 Ditch were analyzed for a broad spectrum of water quality, groundwater quality, and Appendix VIII constituents. Also, a previous report (Riley et al. 1986) had identified the presence of low, but detectable quantities of PCBs (range -6 to $230 \mu / \mathrm{kg}$ ) in B-pond sediments. Therefore, although not reported to be a constituent of A-29 Ditch effluents, samples were also analyzed for PCBs. Table 5 summarizes these parameters. Additional information on analytical procedures and individual hazardous waste constituents is contained in the following procedures section and in Appendices A and B.

\subsection{ANALYTICAL PROCEDURES}

Analytical services for hazardous waste constituents in environmental media were conducted by the UST, Richland Division. All laboratory work aspects were covered by procedures, Quality Assurance and Quality Control Manuals. These manuals were:

Procedure Manual UST-RD-PM-9-80, Rev. 3, 03/86.

Counting Room Operating Procedures UST-RD-PM-9-80, Rev 2, 02/86.

Quality Control Manual UST-RE-QC-9-80, Rev. 4, 09/86.

Quality Assurance Manual UST-RD-QA-7-80, Rev. 7, 03/86.

Whenever available, SW-846 methods (EPA, 3rd ed., 1986 "Test Methods for Evaluating Solid Waste Physical/Chemical Methods") were used. Where SW-846 did not provide sufficient information to analyze for a particular constituent, another standard method (EPA) was used. Table 6 contains a summary comparison of the SW-846 and UST methods. Detailed information for each of these methods is provided in Section 3.2, Analytical Methods. A listing of individual analytes, as well as laboratory QA/QC methods, are presented in Appendices A and $\mathrm{B}$. 
HNF-SD-TWR-TI-005, Rev, 0

Table 5. Analytical Parameters for Selected

Soils Samples from A-29 Ditch.

\begin{tabular}{|l|l|}
\hline & \\
\hline pH & Osmium \\
\hline Conductivity & Strontiuma \\
\hline Mercury & Zinca \\
\hline Ethylene glycol & Calciuma \\
\hline Enhanced thiourea & Magnesiuma \\
\hline Total organic carbon & Nitrate \\
\hline Total organichalides & Sulphate \\
\hline cyanide & Chloride \\
\hline Bariuma & Fluoride \\
\hline Cadmiuma & Phosphate \\
\hline Chromiuma & Phosphate pesticides \\
\hline Leada & Chlorinated pesticides \\
\hline Silvera & Arsenic \\
\hline Sodiuma & Ammonium \\
\hline Nickela & Selenium \\
\hline Coppera & Thallium \\
\hline Vanadiuma & Uranium \\
\hline Antimonya & Sulfide \\
\hline Aluminuma & Chlorinated herbicides \\
\hline Manganesea & voA enhanced \\
\hline Potassiuma & Gross beta \\
\hline Irona & Gross alpha \\
\hline Berylliuma & polychlorinated biphenyls \\
\hline & alnducively coupled plasma meals. \\
\hline
\end{tabular}

anductively coupled plasma metals. 


\begin{tabular}{llll}
\hline & \multicolumn{1}{c}{ Table 6. Comparison of U.S. Environmental Protection Agency and } \\
U.S. Testing Methods
\end{tabular}

aWhen EPA methods were not available, techniques from Standard Methods (16th edition) were used whenever possible.

bAluminum, silver, barium, beryllium, calcium, cadmium, chromium, copper, iron, potassium, magnesium, manganese, sudium, nickel, osmium, lead, antimony, tin, strontium, vanadium, and zinc.

CField measurement. 
HNF-SD-TWR-TI-005, Rev. 0

\subsection{ANALYTICAL METHODS}

A brief description of each of the analytical methods utilized for hazardous waste constituents is provided below (Hembree et al. 1986, UST 1986). The EPA and UST methods are in parentheses.

\section{Gross Alpha}

This measurement (EPA 680/4-75-001; UST No. 112) is made to assess the radiological hazard to laboratory personnel from alpha-emitting isotopes that may be present. An aliquot of sample is evaporated to dryness and counted in a gas flow counter.

\section{Gross Beta}

The possible radiological hazard to laboratory workers from beta/gamma emitters is evaluated with this procedure (EPA 680/4-75-001; UST No. 111). An aliquot is evaporated to dryness and counted on a gas flow counter.

\section{Metals}

Twenty-one metals are determined simultaneously by inductively coupled argon plasma (ICP) spectroscopy (SW-846/\#6010; U.S. Testing No. 726). All of the priority pollutant metals except mercury are measured. Other metals determined are toxic and mandated by Ecology or are of general interest for waste classification and management. The analytes determined are:
- Aluminum
- Silver
- Barium
- Beryllium
- Calcium
- Cadmium
- Chromium
- Copper
- Iron
- Potassium
- Magnesium
- Manganese
- Sidum
- Nickel
- Osmium
- Lead
- Antimony
- Tin
- Strontium
- Vanadium
- Zinc. 


\section{$\underline{\text { Mercury }}$}

Cold vapor atomic absorption spectroscopy (SW-846/\#7470; UST No. A21) is used to quantify mercury. Mercury is reduced to the elemental state and purged from the solution into a cell positioned in the light path of an atomic absorption spectrometer. Absorption at $253.7 \mathrm{~nm}$ is a function of mercury concentration.

\section{Uranium}

No SW-846 method for uranium analysis exits. An in-house method (UST 08 No. 20-U-03-01) consisting of uranium purification by solvent extraction or anion exchange and quantification by fluorometry was used.

\section{Ammonia}

No SW-846 method is provided for ammonia, so Standard Method (1985) No. 417-A-E (UST No. C80) is used. An ammonia selective electrode is used to quantify the ammonia after adjusting the sample $\mathrm{pH}$ to above 11. Ammonia is complexed by silver and mercury, causing a low bias.

\section{Anions}

Chloride, fluoride, nitrate, sulfate, and phosphate are determined by ion chromatography. This method was developed by UST (UST No. 78) and is similar to other methods published in the open literature. While no official EPA or Ecology methods are formalized both agencies use ion chromatography extensively. The sample, nominally $100 \mathrm{~mL}$ and containing a mixture of the anions, is injected into the chromatograph. With proper selection of experimental conditions, the anions exit the instrument singly and are detected through the electrical conductivity.

\section{Total Organic Carbon}

The total organic carbon (TOC) content of a sample is determined (Standard method No. 505; UST No. C69) to cross-check the specific organic compound analyses. If the TOC exceeds the sum of the individual organic compounds found, the significant quantities of organics are present but neither identified nor quantified. If the sample TOC is exceeded by the sum of the individual organics found, then at least one specific organic analysis is in error. The TOC does not identify or quantify any specific compound.

The sample aliquot is combusted quantitatively and the $\mathrm{CO}_{2}$ generated is quantified by automatic titration. All values reported are the average of duplicate analyses.

\section{Total Organic Halides}

Total organic halides (chlorides, bromides, and iodides, but not fluorides are determined (SW-846/No. 9020; UST No. C68) by absorbing them from the sample onto activated charcoal. the activated charcoal is pyrolized to convert organic halides into inorganic halides and the halides are quantified by microcoulometric-titration. Sample bottles must have no headspace to 
prevent loss of volatile compounds. As with TOC, this method reveals the presence of a class of compounds but identifies and quantifies none. These results are generated for comparison with specific organic analyses (volatile organic analyses, herbicides, pesticides, direct-injection organics, and acid/base/neutral extractable organics) to decide if additional analyses are needed. All reported data are the average of duplicate analyses unless stated otherwise.

\section{Volatile Organic Analyses}

Fifty-three organic compounds are simultaneously determined with this method (SW-846/No. 8240; UST No. 731). The list of compounds regulated by Ecology. The analytes are purged from the waste by an inert gas and trapped onto a sorbent column. After purging is complete, the sorbent column is heated to flush the compounds into a gas chromatograph/mass spectrometer (GC/MS) where they are identified and quantified. When the sample is collected, absolutely no headspace (air) is allowed in the sample bottle to prevent loss of volatile compounds.

\section{Extractable Organics}

One hundred forty-one organic compounds are identified and quantified by this method (SW-846/No. 8270; UST No. 733). The sample (usually $1 \mathrm{~L}$ ) is extracted with methylene chloride under acidic, basic, and neutral conditions. The methylene chloride, containing the extracted organic compounds being determined, is injected into a GC/MS for identification and quantification. The compounds determined by this method are tested as EPA-priority pollutants and also include as many of those compounds listed by WAC-173-303-9905 (Ecology 1986) that UST can determine.

\section{Total Cyanide}

The sample is distilled, converting the cyanide into hydrogen cyanide which is trapped in $\mathrm{NaOH}$ solution. Quantification is accomplished by titration with silver nitrate (SW-846/ No. 9010; UST No. C70). Note: This method will not determine reactive cyanides in samples that contain significant concentrations of iron, which is the case with some Hanford wastes.

\section{$\underline{\text { Sulfides }}$}

Total and dissolved sulfides (except acid insoluble sulfides such as $\mathrm{CuS}$ ) are determined by this method (SW-846/No. 9030, UST No. C78). The sample is treated by the addition of excess iodine, which oxidizes sulfide to elemental sulfur in the acidified sample. Sodium thiosulfate or phenylarsine oxide is used to back titrate the remaining excess iodine. 
HNF-SD-TWR-TI-005, Rev. 0

\section{Organochlorine Pesticides}

Most organochlorine pesticides, and if desired, polychlorinated biphenyls (PCBs), are determined by this method (SW-846/No. 8080; UST No. 729). The pesticides are extracted from the sample (which is at neutral $\mathrm{pH}$ ) with methylene chloride and then injected into a GC equipped with an electron capture detector. If peak identification is uncertain, the extracted pesticides are analyzed by GC/MS. Those data are of higher than usual quality because the EPA and Ecology protocol requires that every sample analyzed be spiked to determine the recovery and detection limit for that particular sample.

\section{Organophosphorus Pesticides}

This method (SW-846/No. 8140; UST No. 734) quantifies regulated phosphorus pesticides. Methylene chloride is used to extract the pesticides from the neutral sample. Gas chromatography using a phosphorus-specific detector or a mass spectrometer is used for the final quantification. Every sample is spiked to determine the detection limits, recovery, and freedom from analytical interference for each sample.

\section{Chlorinated Herbicides}

Common regulated chlorinated herbicides are determined with this method (SW-846/No. 8150; UST No. 737). These compounds are manufactured and used in various forms (acid, salt, ester, etc.). The method includes a hydrolysis step to convert all chemical forms into the acid before analysis.

The samples are spiked, hydrolized with $\mathrm{KOH}$, acidified with $\mathrm{H}_{2} \mathrm{SO}_{4}$, extracted with diethyl ether, converted to methyl esters with diazomethane, and quantified by gas chromatography.

The method is tedious and requires vigilant and careful execution because of the use of diethyl ether and diazomethane. 
HNF-SD-TWR-TI-005, Rev. 0

This page intentionally left blank. 


\subsection{SAMPLING PROCEDURES FOR SOIL/SEDIMENT}

\subsection{APPLICABLE STANDARDS}

Site investigations were conducted in accordance with applicable DOE Orders and Operations and Engineering Contractor Procedures, and the Occupational Safety and Health Administration (OSHA) requirements for Hazardous Waste Operations and Emergency Response. Sampling design, methods, equipment, preservation, quality control, and analytical procedures conformed to the degree practical, with the EPA guidance contained in SW-846 (EPA 1982).

1. DOE Order 5780.1A, "Environmental Protection, Safety, and Health Protection Program for DOE Operations."

2. DOE-RL Order 5480.1, "Environmental Protection, Safety, and Health Protection Program for Richland Operations."

3. DOE Order 5480.2, "Hazardous and Radioactive Mixed Waste Management."

4. DOE Order 5480.4, "Environmental Protection, Safety, and Health Protection Standards."

5. DOE-RL Order 5480.4, "Environmental Protection, Safety, and Health Protection Standards."

6. DOE-RL Order 5480.11, "Requirements for Radiation Protection."

7. DOE Order 5480.14, "Comprehensive Environmental Response, Compensation, and Liability Act Program."

8. DOE Order 5484.1, "Environmental Protection, Safety, and Health Protection Information reporting Requirements."

9. DOE-RL Order 5484.1, "Environmental Protection, Safety, and Health Protection Information reporting Requirements."

10. DOE Order 5700.6A, "Quality Assurance."

11. DOE-RL Order 5700.1A. "Quality Assurance."

12. RHO-GM-MA-2, Volume 1, Book 2, Section 14, "Records Management."

13. RHO-GM-MA-2, Volume 3, Book 1, Section 31, "Management Control System." 
14. RHO-GM-MA-2, Volume 3, Book 2, Section 33, "Performance Assessment and Analysis."

15. RHO-GM-MA-2, Volume 4, Book 1, Section 43, "Operations."

16. RHO-GM-MA-2, Volume 5, Book 2, Section 52, "Property," Section 53, "Procurement," and Section 54, "Shipping and Receiving."

17. RHO-GM-MA-2, Volume 6, Book 1, Section 61, "Safety," and Section 62, "Environment."

18. RHO-GM-MA-2, Volume 6, Book 2, Section 63, "Emergency Situation," and Section 64, "Health."

19. Title 42 USC 6901, et. seq., "Resource Conservation and Recovery Act of 1976 (RCRA), as amended.

20. Title 42, USC 9601, et. seq., (Superfund), "Comprehensive Environmental Response, Compensation, and Liability Act of 1980."

21. Pub. L. 99-499, "Superfund Amendments and Reauthorization Act of 1986" (SARA).

22. Title 29, USC 655, 657, "Occupational Safety and Health Act of 1970" (OSHA).

23. 29 CFR 1910, "Hazardous Waste Operations and Emergency Response," OSHA Interim Final Rule, Federal Register, Vol. 51, No. 244, December 19, 1986.

\subsection{SAMPLE DESIGN}

The sampling design and strategy was based on the sampling plan development information contained in SW-846 (EPA 1982) and other EPA guidance manuals and technical documents (DeVera et. al 1980; Mason 1983; Barth and Mason 1984; EPA 1983; Ford et al. 1984; Ford and Torina 1985). Based on the configuration of the site and the environmental conditions that existed there, the sampling strategy was proposed to characterize the sediments of the A-29 Ditch. The primary objectives of this sampling effort were to:

- Determine whether or not the soils and sediments of the ditch contained hazardous waste constituents

- Determine which specific hazardous constituents might be present in significant quantities and their concentrations 
- Provide data and information for input to a future technical assessment of closure options for this unit.

\subsection{GUIDANCE DOCUMENTS}

A number of guidance documents and resource publications have been developed for use in preparing, designing, and executing adequate soil sampling program. The following were used where appropriate:

Samplers and Sampling Procedures for Hazardous Waste Streams,
EPA-600/2-80-018 1980,
Characterization of Hazardous Waste Sites - A Methods Manual, 1984,
EPA-600/4-84-076
Preparation of Soil Sampling Protocol: Techniques and Strategies, 1983 ,
EPA-600/4-83-020
Soil Sampling Quality Assurance User's Guide, 1984, EPA-600/4-84-043.

\subsection{SAMPLE LOCATIONS}

The open portion of the ditch, which is approximately $1,330 \mathrm{~m}(4,360 \mathrm{ft})$ long, was divided into two sections to facilitate a stratified sampling approach. The upper head-end section of the ditch, which comprised the first $732 \mathrm{~m}(2,400 \mathrm{ft})$, received more intensive scrutiny because of the higher probability that various types of hazardous waste could concentrate in the sediments and soils of this section. The principle reasons for this rational were the greater depth of water in this upper section, lower flow rates when PUREX was not operating, and low waterflow speed because of the relatively small drop in gradient compared with the lower ditch area. Six sample sites were located along this section. An additional four samples sites were located along the lower $609 \mathrm{~m}(2,000 \mathrm{ft})$ of A-29 Ditch.

\subsection{SAMPLE CONTAINERS AND PRESERVATION}

Containers for hazardous waste samples were chosen based on their compatibility with the waste, resistance to leaking or breakage, ability to seal tightly, and required volume for an optimum sample. Containers for collecting and sorting hazardous waste samples were made of high-density plastic or glass bottles. The containers had tight, screw-type lids with Teflon or plastic liners. Table 7 contains a summary of the types and volumes used in the sample analysis. Table 8 contains a summary of the containers and preservation utilized for soil and sediment samples. 
Table 7. Sample Preservation Details.

\begin{tabular}{|c|c|c|c|}
\hline Analyte & Sample volume & Container/lid & Preservation \\
\hline $\begin{array}{l}\text { Gross alpha } \\
\text { Gross beta } \\
\text { Metalsb } \\
\text { Mercury } \\
\text { Ammonia } \\
\text { Anionsc } \\
\text { Total organic carbon } \\
\text { Total organic halide } \\
\text { Volatile organics analysis } \\
\text { Extractable organicse } \\
\text { Direct injection organies } \\
\text { Cyanide } \\
\text { Sulfide }\end{array}$ & $\begin{array}{rl}1 & \mathrm{~L} \\
1 & \mathrm{~L} \\
250 \mathrm{~mL} \\
250 \mathrm{~mL} \\
250 \mathrm{~mL} \\
250 \mathrm{~mL} \\
250 \mathrm{~mL} \\
250 \mathrm{~mL} \\
40 \mathrm{~mL} \\
1 \mathrm{~L} \\
10 \mathrm{~mL} \\
1 \mathrm{~L} \\
1 \mathrm{~L}\end{array}$ & $\begin{array}{l}\text { plastic/Tefion } \\
\text { plastic/Teflon } \\
\text { plastic/Tefion } \\
\text { plastic/Tefion } \\
\text { glass/Teflon } \\
\text { plastic/Teflon } \\
\text { glass } \\
\text { glassd } \\
\text { glassd } \\
\text { glass/Teflon } \\
\text { glass/Tef lon } \\
\text { plastic/Teflon } \\
\text { plastic/Tefion }\end{array}$ & 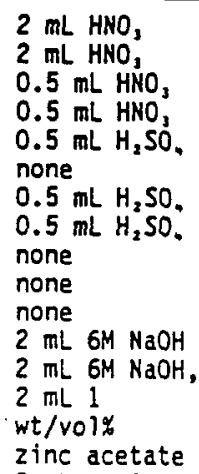 \\
\hline Uranium & $1 \mathrm{~L}$ & plastic/Tefion & $2 \mathrm{~mL}, \mathrm{HNO}_{3}$ \\
\hline
\end{tabular}

aAll samples shall be cooled to $4^{\circ} \mathrm{C}$ upon collection.

Baluminum, silver, barium, beryllium, calcium, cadmium, chromium, copper, iron, potassium, magnesium, manganese, sodium, nickel, osmium, lead, antimony, tin, strontium, vanadium, and zinc.

chloride, fluoride, nitrate, sulfate, and phosphate.

dGlass container with silicone/Teflon septa, no headspace.

efrom acidic, basic and neutral sample solutions. 
Table 8. Sample Containers, Preservation Requirements, and Holding Times for Soil Samples. (sheet 1 of 2)

\begin{tabular}{|c|c|c|c|}
\hline Contaminant & Container & Preservation & Holding time \\
\hline Acsdity & P.G & Cool, $4 \cdot c$ & $14 d$ \\
\hline Alkalinity & P.G & Cool, $4 \propto C$ & $14 d$ \\
\hline Ammonia & P.G & $\mathrm{CoOl}, 4 \propto \mathrm{C}$ & $28 d$ \\
\hline Sulfate & P.G & $\operatorname{CoO}, 4 \times C$ & $28 d$ \\
\hline Sulfide & P.G & Cool. $4-C$ & $28 d$ \\
\hline Sulfite & $P, G$ & CoOl. $4 \cdot 5$ & $48 n$ \\
\hline Nitrate & P. G & Cool. $4 \cdot C$ & $48 \mathrm{~h}$ \\
\hline Nitrate-Nitrite & P.G & $\mathrm{CoOl}, 4 \cdot \mathrm{C}$ & $28 d$ \\
\hline Nitrite & $P, G$ & $C 001,4 \cdot C$ & $48 \mathrm{~h}$ \\
\hline Oll and grease & $G$ & $6001,4 \cdot C$ & $28 d$ \\
\hline Organic carbon & $P, G$ & $\mathrm{CoO}, 4 \cdot \mathrm{C}$ & $28 \mathrm{~d}$ \\
\hline$\frac{\text { Metals }}{\text { Chromtum VI }}$ & P. G & Cool, $4 \propto C$ & $48 \mathrm{~h}$ \\
\hline Mersury & P. G & & $28 d$ \\
\hline Metals except above & $P . G$ & & 6 mo \\
\hline $\begin{array}{l}\text { Organic Compounds } \\
\text { Extractables (Inluding } \\
\text { phthalates, nitrosamines } \\
\text { organochlorine pesticides, PCBs } \\
\text { nitroaromatio, isophorone. } \\
\text { Polynuelear aromatic hydro- } \\
\text { carbons. haleothers, shlorin. } \\
\text { ared hydrocárbons and TCDD) }\end{array}$ & $\begin{array}{l}\text { G.teflon. } \\
\text { lined cap }\end{array}$ & $\mathrm{CoOl}, 4 \cdot \mathrm{C}$ & $\begin{array}{l}7 d \text { (until } \\
\text { extraction) } \\
30 d \text { (atter } \\
\text { extraction) }\end{array}$ \\
\hline Extractables (phenols) & $\begin{array}{l}\text { G. teflon: } \\
\text { lined cap }\end{array}$ & $\operatorname{cool}, \Delta \cdot C$ & $\begin{array}{l}7 \mathrm{~d} \text { (until } \\
\text { extraction) } \\
30 \mathrm{~d} \text { (atter } \\
\text { extraction) }\end{array}$ \\
\hline $\begin{array}{l}\text { Purgables (halocarbons and } \\
\text { aromatics) }\end{array}$ & $\begin{array}{l}\text { G. teflon- } \\
\text { lined septum }\end{array}$ & $C o o l, 4 \times C$ & $14 d$ \\
\hline $\begin{array}{l}\text { Purgables (acroten and } \\
\text { acrylonitrate) }\end{array}$ & $\begin{array}{l}\text { G, teflon:- } \\
\text { lined septum }\end{array}$ & $\mathrm{CoOl}, 4 \cdot \mathrm{C}$ & $3 d$ \\
\hline Orthophosphate & P.G & $\mathrm{CoOl}, 4 \propto$ & $48 \mathrm{~h}$ \\
\hline Pesticides & $\begin{array}{l}\text { G. tefion- } \\
\text { lined cap }\end{array}$ & $6001,4 * 5$ & $\begin{array}{l}7 d \text { (until } \\
\text { extraction) } \\
30 \text { dater } \\
\text { extraction) }\end{array}$ \\
\hline
\end{tabular}


Table 8. Sample Containers, Preservation Requirements, and Holding Times for Soil Samples. (sheet 2 of 2)

\begin{tabular}{|c|c|c|c|}
\hline Contaminant & Container & Preservation & Holding time \\
\hline Phenols & $P, G$ & Cool, \& $<$ & $28 \mathrm{~d}$ \\
\hline Phosphorus (elemental) & $G$ & Cool. $4 \propto$ & $48 h$ \\
\hline Phosphorus (total) & $P, G$ & Cool. $4 \alpha$ & $28 d$ \\
\hline $\begin{array}{l}\text { Chlorinated organic } \\
\text { compounds }\end{array}$ & $P, G$ & Cool. $4 \cdot C$ & $\begin{array}{l}7 d \text { (until extraction) } \\
30 \text { of (after extraction) }\end{array}$ \\
\hline
\end{tabular}

- Polyechylene.

mstal.311.

$G=$ Glass.

Sample preservation should be performed immediately upon sample collection. For composite samples each aliquot should be preserved at the time of collection. When impossible to preserve each aliquot, then samples may be preserved by maintainin at $\Delta+C$ until compositing and sample spliting is completed.

samples shold be analyzed as soon as possible atter collection. The times listed are the maximum times that samples may be held before analysis and still considered varld Samples $m$ ay be held for samples under study are stable for the longer time

For additional unformation, see ford et al. (1983). 
HNF-SD-TWR-TI-005, Rev. 0

\subsection{SAMPLE PLAN MODIFICATIONS}

Under field conditions, the optimal aspects of preliminary sample design were not always achievable. Factors influencing these efforts were occasional equipment malfunction, adverse weather conditions, soil conditions, and physical barriers to coring equipment. Therefore, modifications to the proposed sample design sometimes became necessary. These changes, all of which were minor, were noted in the field logbook, and did not affect the quality of the field data or sampling efforts. 
HNF-SD-TWR-TI-005, Rev. 0

This page intentionally left blank.

4-8 


\subsection{FIELD ACTIVITIES}

The sampling for A-29 Ditch was initiated on May 24, 1988. A team of four scientists and an RPT comprised the sampling team. Following a safety meeting, sampling was initiated at sample site 1 shown in Figure 4. A portable wooden bridge was utilized to place over the flowing portion of the ditch and the sample was collected from the middle of the ditch using a stainless-steel hand auger. The auger head was $7.6 \mathrm{~cm} \mathrm{(3} \mathrm{in.)} \mathrm{in} \mathrm{diameter} \mathrm{and} 33 \mathrm{~cm} \mathrm{(13} \mathrm{in.)}$ long. An initial sample was collected from the surface sediments to a depth of $30 \mathrm{~cm}(12 \mathrm{in}$.) whenever possible. Gravelly areas would occasionally not allow penetration to the full $30 \mathrm{~cm}$ (12 in.). Whenever possible, a second sample was collected to the greatest depth the auger could penetrate; which was usually 61 to $91 \mathrm{~cm}$ (24 to $36 \mathrm{in}$.) Secondary samples to depth were only possible at sites $1,2,3$, and 9 (Figure 4). A complete summary of the sample depths is provided with the sample data summaries discussed in the following sections.

Pre-cleaned augers were utilized for each sample. A volatile organic detector was used to provide a check on each sample as it was pulled. There were no positive readings above background levels for any of the samples collected. Samples from sites 1 and 2 were collected on May 5, 1988. After these sites were sampled, it was necessary to resume sampling at the southern end of the ditch due to the fence shown in Figure 4. Subsequent samples were collected from the furthest points downstream (sample sites 3 through 10, Figure 4) to reduce the possibility of any cross contamination of upstream samples.

Samples from sites 3, 4, and 5 were collected on May 25, 1988. Sampling was concluded on May 26, 1988, with samples collected from sites 6, 7, 8, 9. and 10. Samples collected from sites 7 and 10 were the only ones which registered radioactivity readings ( $300 \mathrm{cpm}$ and $150 \mathrm{cpm}$, respectively) above background on the Geiger-Mueller (GM) counter.

Following sample collection, the appropriate sample bottles were filled, the exterior wiped down, labeled, sealed in plastic bags, and placed in coolers containing "blue" ice. For each sample collected, a field data sheet was completed showing the sample location, the sample number, time collected, sampling method, name of the sampler, and field notes as needed.

Before transporting to the laboratory, a tamper-proof seal was placed on each sample container. Each sample was double checked for proper seal and labeling. All pertinent field data were recorded in the field logbook. Chain-of-custody and sample analysis request forms were completed and checked. All samples were re-bagged (double bags) and placed on ice or "blue" ice until they were shipped offsite. The sample locations were marked using a surveyor's stake so they could be relocated.

The field sampling information, along with photographs of the sample locations, were recorded in the field logbook and are included in Appendix D. 
Figure 4. A-29 Ditch Sample Locations.

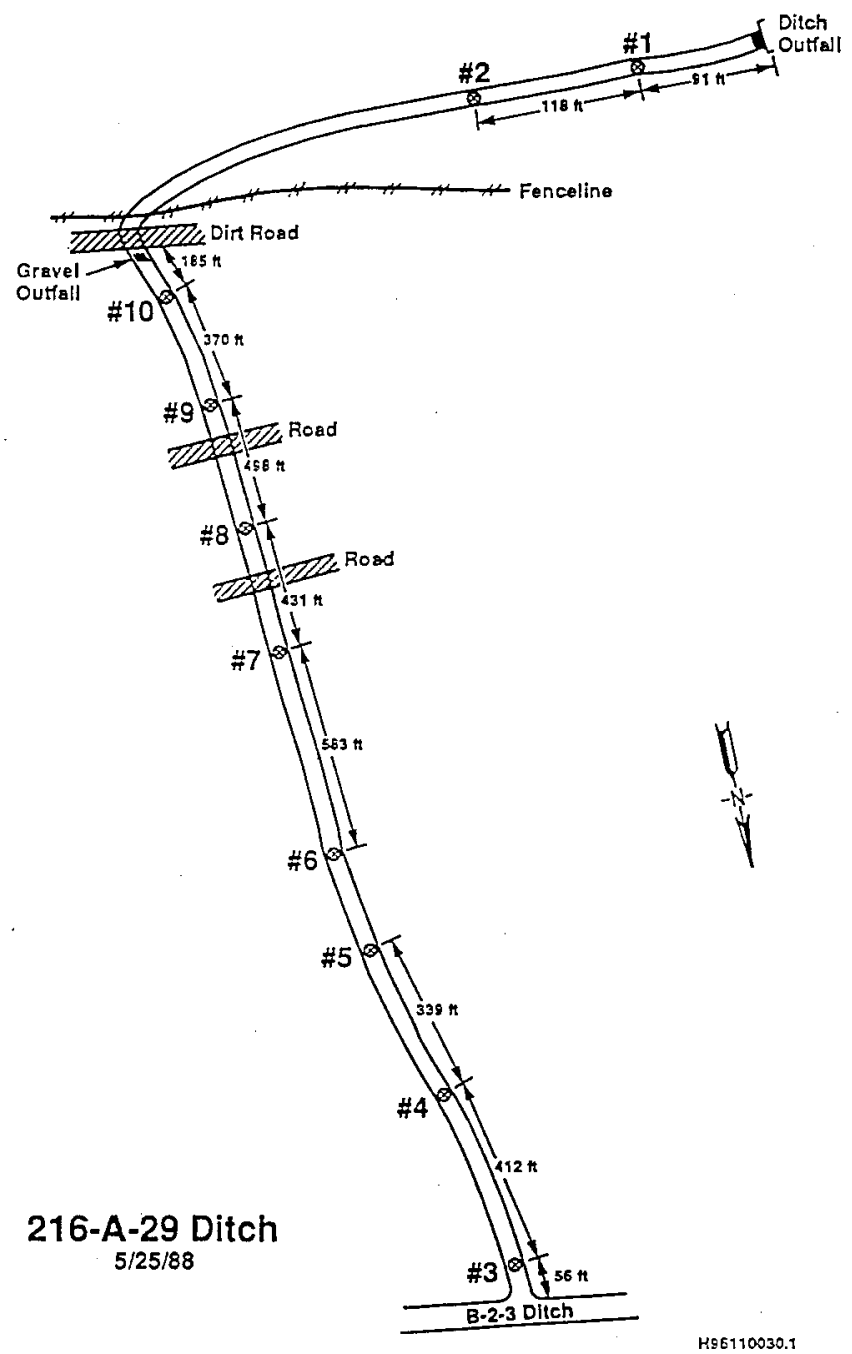


HNF-SD-TWR-TI-005, Rev. 0

\subsection{RESULTS AND DISCUSSION}

This section provides a summary of the laboratory analyses data reported for contaminants of concern, which included radionuclides (total alpha, total beta, cesium-137, cobalt-60, total uranium), metals (strontium, zinc, barium, cadmium, chromium, silver, lead, nickel, copper, mercury, arsenic, and selenium), and organic compounds.

\subsection{RADIONUCLIDES}

For this effort, the sediments were sampled for total alpha, total beta, and total uranium concentrations as well as gamma-emitting radionuclides such as cobalt-60 and cesium-137. Summaries of the radionuclide data for the A-29 Ditch sediments are contained in Tables 9 and 10.

The three highest values reported in the data set for total aipha and total uranium were from sample sites 7, 9, and 10 (Figure 4) and two of the three highest readings for total beta were from sites 7 and 10 (Table 9). One of the higher values for total beta was from site 2 near the head-end of the ditch. The highest value reported for cobalt-60 was also from site 2 , although most of the cobalt values were below detection limits.

The cesium- 137 values demonstrated the greatest amount of variability, with site 10 being the highest reported value $(140 \mathrm{pCi} / \mathrm{g})$ and sites $2,5,7,8$, and 9 having values in excess of $40 \mathrm{pCi} / \mathrm{g}$. The $140 \mathrm{pCi} / \mathrm{g}$ at site 10 exceeded the highest reported cesium-137 value $(127 \mathrm{pCi} / \mathrm{g})$ collected in 1986 by the routine monitoring program for A-29 sediment samples (see Table 3 ).

All of the values reported were below the existing 200 Area soil standards (Booth 1985) of $400 \mathrm{pCi} / \mathrm{g}$ for cesium- 137 and $300 \mathrm{pCi} / \mathrm{g}$ for cobalt -60 .

\subsection{METALS}

There is a paucity of information relative to the concentrations of metals in Hanford Site soils. The most extensive information for the Hanford Site is the Landeen et al. (1993) study conducted in the 100 Areas along the Columbia River. Data are summarized for metals in soils, various types of plants, as well as raptor pellets (hawks, owls), and coyote scat. However, the values obtained must be viewed with some caution since mining and refining activities in upper Columbia River drainages (Johnson 1991; Maxfield 1974; Silker 1964), no doubt, contribute to elevated background levels for metals in river sediments.

The metals data for A-29 Ditch at the 10 sample locations are summarized in Table 11. Most of the cadmium and silver values were below the detection limits, while all of the selenium values were less than detectable and are included for information only.

For comparative purposes, the maximum concentrations for metals data from the A-29 Ditch, 2101-M Pond, a RCRA site in the 200 Areas (DOE-RL 1993), and Landeen et al. (1993) are compared to the Hanford Site Soil Background values (DOE 1993) and are provided in Table 12. 
Table 9. Summary of Radionuclide Data for A-29 Ditch Sediments (pCi/g).

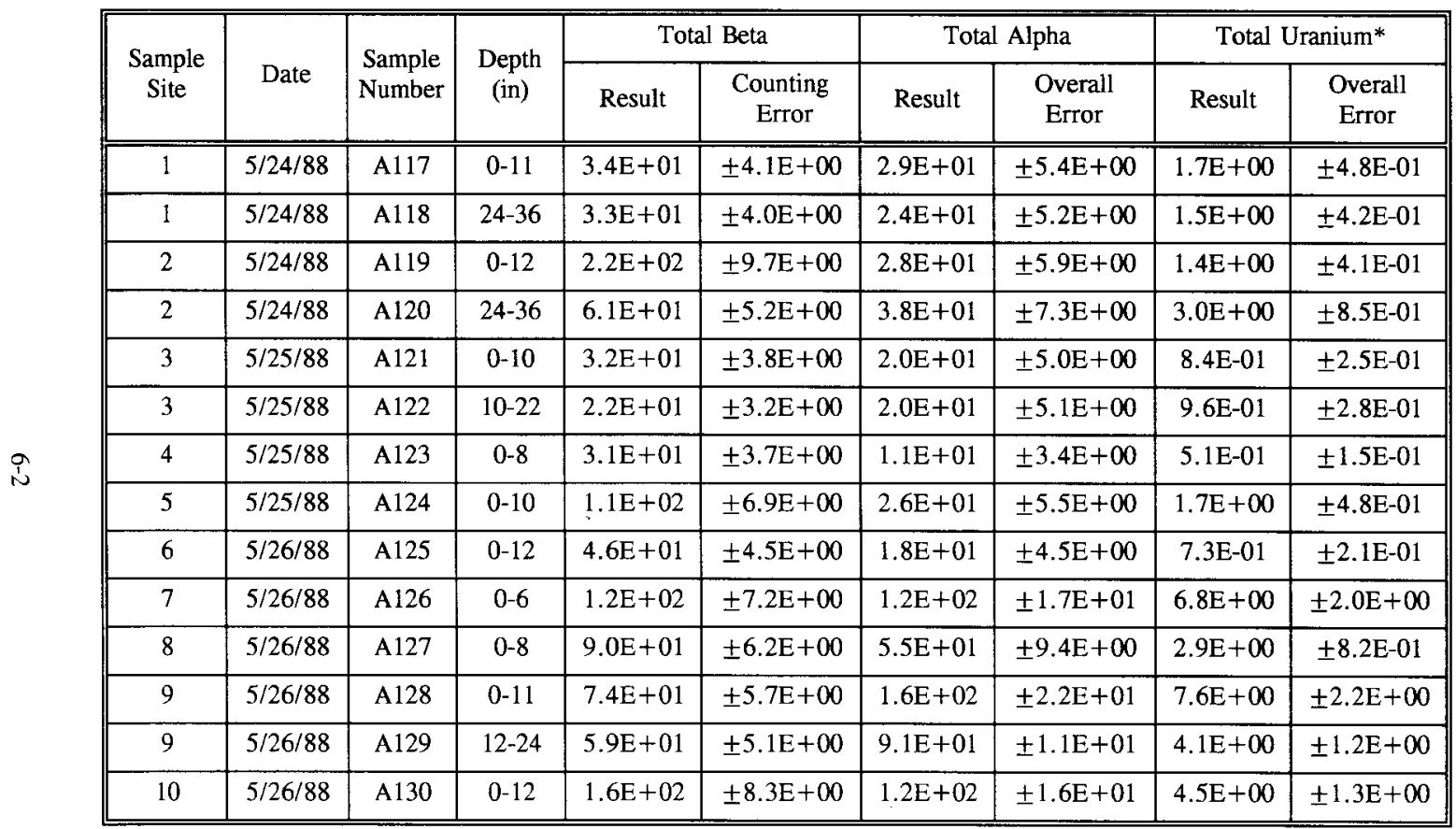


Table 10. Summary of Radionuclide Data for A-29 Ditch Sediments (pCi/g).

\begin{tabular}{|c|c|c|c|c|c|c|c||}
\hline \multirow{2}{*}{$\begin{array}{c}\text { Sample } \\
\text { Site }\end{array}$} & \multirow{2}{*}{ Date } & \multirow{2}{*}{$\begin{array}{c}\text { Sample } \\
\text { Number }\end{array}$} & \multirow{2}{*}{$\begin{array}{c}\text { Depth } \\
\text { (in) }\end{array}$} & \multicolumn{2}{|c|}{ Cobalt - 60 } & \multicolumn{2}{c|}{ Cesium - 137 } \\
\cline { 6 - 8 } & & & Result & Overall Error & Result & Overall Error \\
\hline \hline 1 & $5 / 24 / 88$ & A117 & $0-11$ & --- & -- & $3.7 \mathrm{E}+00$ & $\pm 3.7 \mathrm{E}-01$ \\
\hline 1 & $5 / 24 / 88$ & A118 & $24-36$ & $3.2 \mathrm{E}-02$ & $\pm 2.8 \mathrm{E}-02$ & $9.2 \mathrm{E}-01$ & $\pm 1.2 \mathrm{E}-01$ \\
\hline 2 & $5 / 24 / 88$ & A119 & $0-12$ & $8.5 \mathrm{E}-02$ & $\pm 2.4 \mathrm{E}-02$ & $6.3 \mathrm{E}+01$ & $\pm 6.3 \mathrm{E}+00$ \\
\hline 2 & $5 / 24 / 88$ & A120 & $24-36$ & -- & --- & $1.7 \mathrm{E}+01$ & $\pm 1.7 \mathrm{E}+00$ \\
\hline 3 & $5 / 25 / 88$ & A121 & $0-10$ & -- & $-\cdots$ & $8.2 \mathrm{E}+00$ & $\pm 8.3 \mathrm{E}-01$ \\
\hline 3 & $5 / 25 / 88$ & A122 & $10-22$ & $2.1 \mathrm{E}-02$ & $\pm 2.1 \mathrm{E}-02$ & $6.9 \mathrm{E}+00$ & $\pm 7.0 \mathrm{E}-01$ \\
\hline 4 & $5 / 25 / 88$ & A123 & $0-8$ & --- & -- & $1.1 \mathrm{E}+01$ & $\pm 1.1 \mathrm{E}+00$ \\
\hline 5 & $5 / 25 / 88$ & A124 & $0-10$ & $2.8 \mathrm{E}-02$ & $\pm 2.2 \mathrm{E}-02$ & $7.2 \mathrm{E}+01$ & $\pm 7.2 \mathrm{E}+00$ \\
\hline 6 & $5 / 26 / 88$ & A125 & $0-12$ & -- & --- & $8.4 \mathrm{E}+00$ & $\pm 8.5 \mathrm{E}-01$ \\
\hline 7 & $5 / 26 / 88$ & A126 & $0-6$ & --- & -- & $7.2 \mathrm{E}+01$ & $\pm 7.2 \mathrm{E}+00$ \\
\hline 8 & $5 / 26 / 88$ & A127 & $0-8$ & -- & -- & $1.0 \mathrm{E}+02$ & $\pm 1.1 \mathrm{E}+01$ \\
\hline 9 & $5 / 26 / 88$ & A128 & $0-11$ & -- & --- & $7.3 \mathrm{E}+01$ & $\pm 7.3 \mathrm{E}+00$ \\
\hline 9 & $5 / 26 / 88$ & A129 & $12-24$ & -- & $-\cdots$ & $4.2 \mathrm{E}+01$ & $\pm 4.2 \mathrm{E}+00$ \\
\hline 10 & $5 / 26 / 88$ & A130 & $0-12$ & --- & -- & $1.4 \mathrm{E}+02$ & $\pm 1.4 \mathrm{E}+01$ \\
\hline \hline
\end{tabular}

-.- = below detection limits. 
Table 11. Summary of Metals Data for A-29 Ditch Sediments (ppm). (sheet 1 of 2)

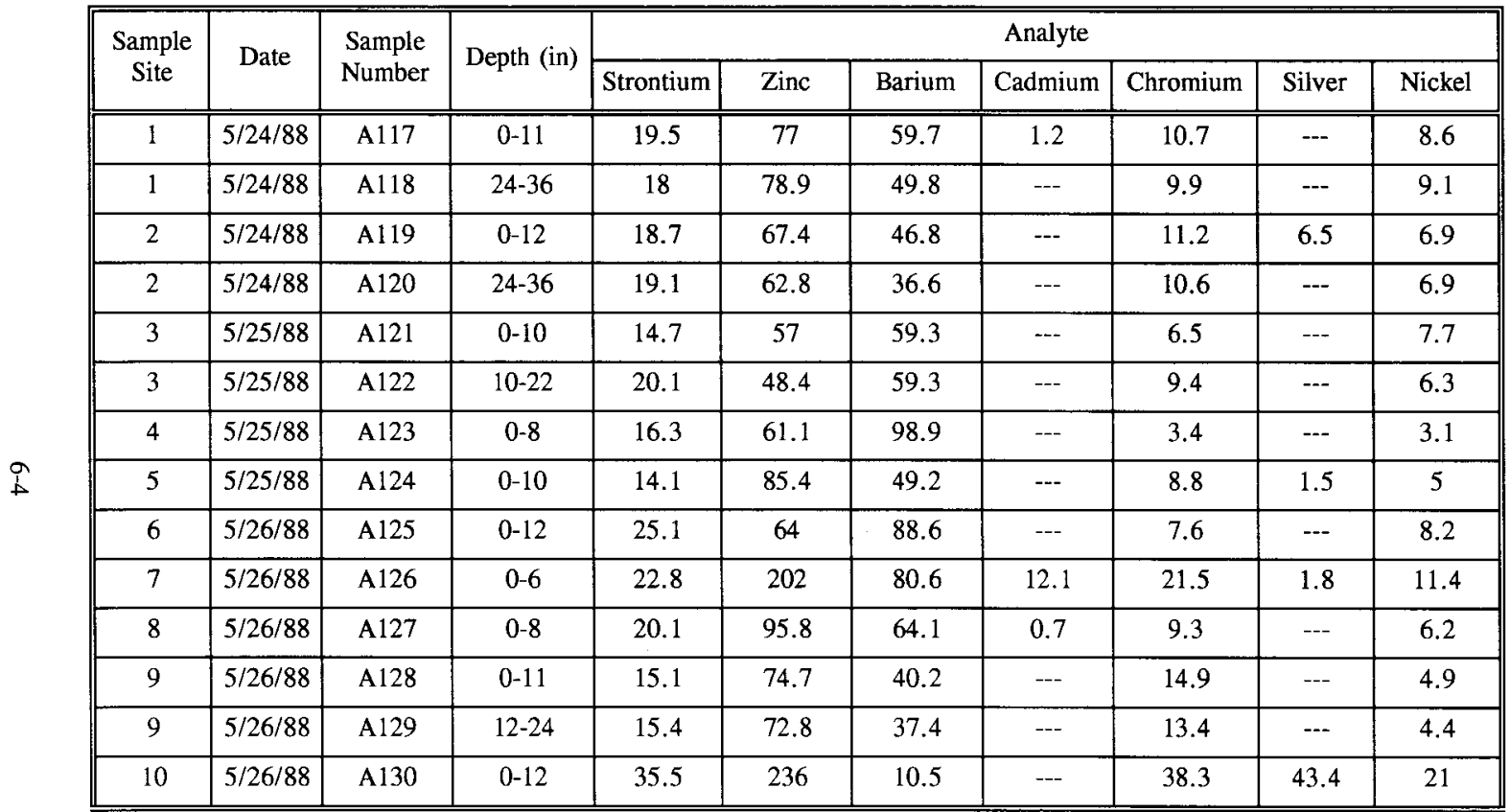


Table 11. Summary of Metals Data for A-29 Ditch Sediments (ppm). (sheet 2 of 2)

\begin{tabular}{|c|c|c|c|c|c|c|c|c|}
\hline \multirow{2}{*}{$\begin{array}{c}\text { Sample } \\
\text { Site }\end{array}$} & \multirow{2}{*}{ Date } & \multirow{2}{*}{$\begin{array}{l}\text { Sample } \\
\text { Number }\end{array}$} & \multirow{2}{*}{ Depth (in) } & \multicolumn{5}{|c|}{ Analyte } \\
\hline & & & & Copper & Mercury & Arsenic & Selenium & Lead \\
\hline 1 & $5 / 24 / 88$ & A117 & $0-11$ & 7.1 & 1.6 & 4.9 & --- & 104 \\
\hline 1 & $5 / 24 / 88$ & Al18 & $24-36$ & 7.9 & 0.8 & 6 & --- & 48 \\
\hline 2 & $5 / 24 / 88$ & A119 & $0-12$ & 5.5 & 1.1 & 2.4 & --- & 39.8 \\
\hline 2 & $5 / 24 / 88$ & A 120 & $24-36$ & --- & 1.3 & 5.2 & $\cdots$ & 98.8 \\
\hline 3 & $5 / 25 / 88$ & A121 & $0-10$ & -- & --- & 1.1 & --- & 53.6 \\
\hline 3 & $5 / 25 / 88$ & A 122 & $10-22$ & -- & 0.5 & 1.4 & --- & 55.4 \\
\hline 4 & $5 / 25 / 88$ & A 123 & $0-8$ & -- & --- & 0.9 & --- & 10 \\
\hline 5 & $5 / 25 / 88$ & A124 & $0-10$ & 15 & 0.5 & 1.2 & --- & 23.6 \\
\hline 6 & $5 / 26 / 88$ & A125 & $0-12$ & --- & 0.69 & 1.1 & --- & 8.7 \\
\hline 7 & $5 / 26 / 88$ & A126 & $0-6$ & 89.2 & 4.6 & 2 & -+- & 67.2 \\
\hline 8 & $5 / 26 / 88$ & A 127 & $0-8$ & 7.8 & 2.1 & 1.3 & -- & 16.1 \\
\hline 9 & $5 / 26 / 88$ & A 128 & $0-11$ & $\cdots$ & 8.1 & 1.4 & --- & 132 \\
\hline 9 & $5 / 26 / 88$ & A129 & $12-24$ & --- & 7.3 & 0.9 & --- & 262 \\
\hline 10 & $5 / 26 / 88$ & A 130 & $0-12$ & 117 & 14.4 & 10 & -- & 147 \\
\hline
\end{tabular}

--- = below detection limits. 
HNF-SD-TWR-TI-005, Rev. 0

Table 12. Comparison of Maximum Metals Values for Soils at Selected Sites (ppm).

\begin{tabular}{|c|c|c|c|c|}
\hline Analytes & A-29 Ditch & 2101-M Pond & 100 Areas $^{b}$ & $\begin{array}{l}\text { Background } \\
\text { values }^{c}\end{array}$ \\
\hline Zinc & 236 & 360 & 237 & 79 \\
\hline Barium & 98.9 & 130 & 316 & 175 \\
\hline Cadmium & 12.1 & 2.7 & 1.8 & $\mathrm{NC}(11)^{\mathrm{d}}$ \\
\hline Chromium & 38.3 & 33 & 76.1 & 28 \\
\hline Silver & 43.4 & 32 & 2 & 2.1 \\
\hline Nickel & 21 & 17 & 17 & 25 \\
\hline Copper & 117 & 2,500 & 26.8 & 30 \\
\hline Mercury & 14.4 & 0.9 & 0.05 & 1.3 \\
\hline Arsenic & 10 & 4 & 3 & 9 \\
\hline Lead & 147 & 160 & 13.5 & 14.9 \\
\hline
\end{tabular}

${ }^{2}$ DOE-RL 1989.

'Landeen et al. 1993.

${ }^{'}$ Hanford Site Soil Background (DOE 1993).

${ }^{\mathrm{d}}$ Not calculated (number in parenthesis maximum observed). 
In reviewing the metals data in Table 11, some trends become apparent. Sites 7 and 10 (see Figure 4) have the vast majority of maximum concentrations reported. If we look at the high and second highest values reported for all sample locations, site 10 has 9 of the 22 reported values $(41 \%)$, site 7 has 5 of the $22(23 \%)$, while no other sample site has more than $2(9 \%)$ of the highest values. Additionally, site 10 has 8 of the 11 maximum values (73\%) reported for each analyte (Table 11).

The proposed improvements that will cross the A-29 Ditch in support of the TWRS Phase 1 Privatization Project are in the general proximity of sample sites 7, 8, and 9 (Figure 4) as mentioned previously. Sample site 7 had 5 of the highest metals values reported, sample site 8 had none, and sample site 9 had 2 . The proposed corridor for development would be very near the location for sample site 8 . Table 13 contains a summary of the highest values reported for each analyte as well as the ranking for the metals values reported at these three sites. For comparative purposes, rankings were provided for only the two highest values for each analyte.

\subsection{OTHER ANALYTES}

Table 14 summarizes the analytical data reported for anions, ammonia, TOC and cyanide. Although some constituent values were all below detection limits (fluoride, phosphate, and cyanide), they are included for information. With regard to the other analytes, such as volatile organic compounds, semi-volatile organics, chlorinated herbicides, organophosphorus pesticides, PCBs, and anions (Table 15), the values reported were less than detection limits, at detection limits, or within normal ranges for the Hanford Site (DOE 1993).

In summary, the range of values reported for radionuclides at A-29 Ditch were all within the Hanford Site soil standards (Booth 1985). With regard to A-29 Ditch metals, the values reported for metals are below the soil cleanup limits proposed in the Model Toxics Control Act (Ecology 1992), with the possible exception of arsenic. However, the range of values reported for arsenic from the A-29 Ditch are within the values reported for Hanford Site Soil Background (DOE 1993) values (Table 12) and well below the maximum reported background concentration of $27.7 \mathrm{ppm}$. 
HNF-SD-TWR-TI-005, Rev. 0

Table 13. Comparison of Maximum Metals Values for Soils at Selected Sites (ppm).

\begin{tabular}{|l|c|c|c|c|c|c||}
\hline \hline Analytes & Site 7 & Rank & Site 8 & Rank & Site 9* & Rank \\
\hline \hline Zinc & 202 & 2 & 95.8 & & 74.7 & \\
\hline Barium & 80.6 & & 64.1 & & 40.2 & \\
\hline Cadmium & 12.1 & 1 & 0.7 & & LTD & $\cdots$ \\
\hline Chromium & 21.5 & 2 & 9.3 & & 14.9 & \\
\hline Silver & 1.8 & & LTD & -- & LTD & $\cdots$ \\
\hline Nickel & 11.4 & 2 & 6.2 & & 4.9 & \\
\hline Copper & 89.2 & 2 & 7.8 & & LTD & --- \\
\hline Mercury & 4.6 & & 2.1 & & 8.1 & 2 \\
\hline Arsenic & 2 & & 1.3 & & 1.4 & \\
\hline Lead & 67.2 & & 16.1 & & 262 & 1 \\
\hline \hline
\end{tabular}

* = Highest value for 2 samples collected.

LTD $=$ Less than detection limits. 
HNF-SD-TWR-TI-005, Rev. 0

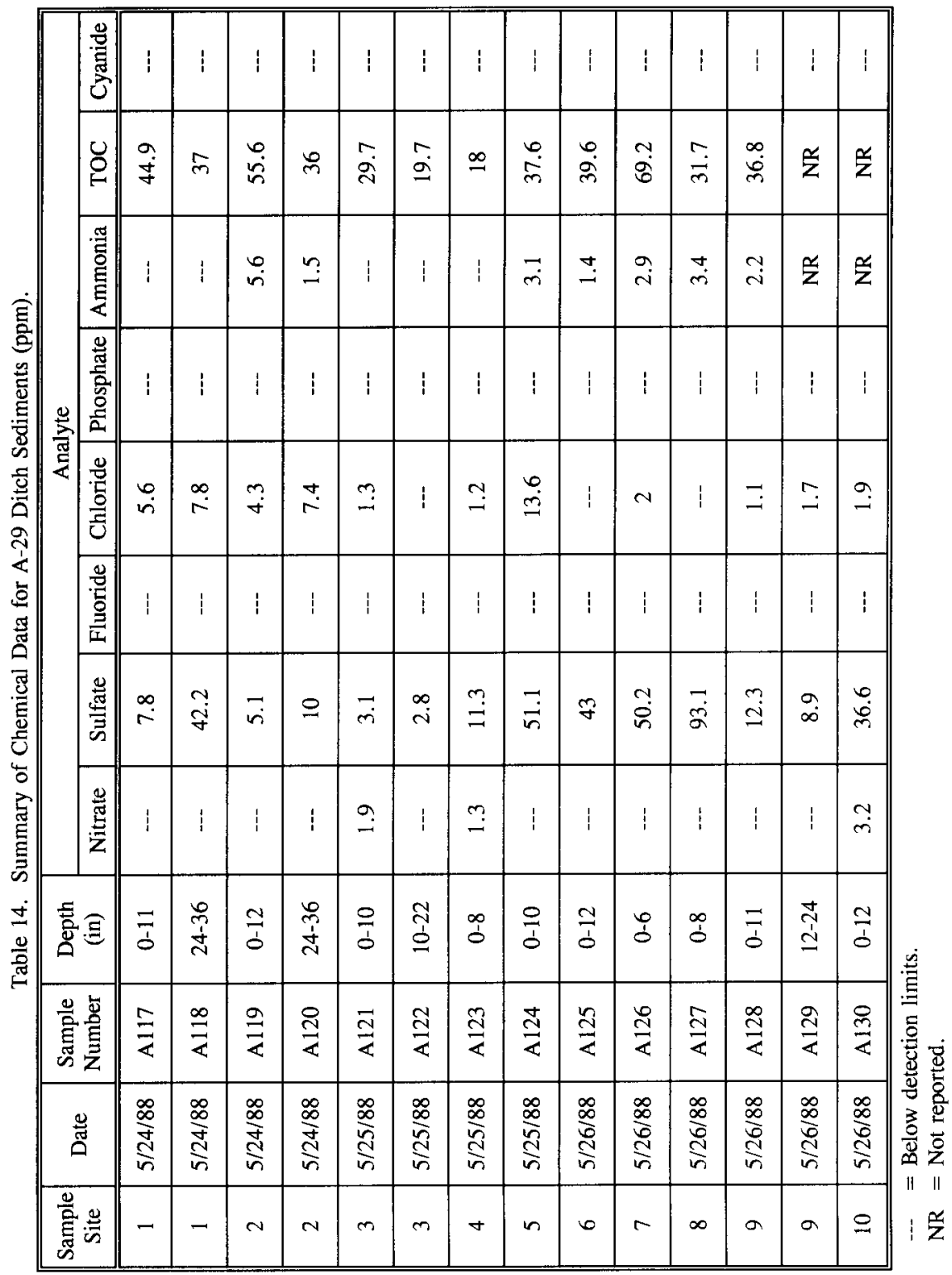


Table 15. Summary of Organic and Chemical Analytes for A-29 Ditch Sediments (ppm).

\begin{tabular}{|c|c|c|c|c|c|c|c|c|c|c|c|c|}
\hline \multirow{2}{*}{$\begin{array}{l}\text { Sample } \\
\text { Site }\end{array}$} & \multirow{2}{*}{ Date } & \multirow{2}{*}{$\begin{array}{l}\text { Sample } \\
\text { Number }\end{array}$} & \multirow{2}{*}{$\begin{array}{l}\text { Depth } \\
\text { (in) }\end{array}$} & \multicolumn{9}{|c|}{ Analyte } \\
\hline & & & & $\begin{array}{c}\text { Extractable } \\
\text { Organics }\end{array}$ & $\begin{array}{l}\text { Organochlorine } \\
\text { Pesticides }\end{array}$ & PCBs & $\begin{array}{l}\text { Chlorinated } \\
\text { Herbicides }\end{array}$ & $\begin{array}{l}\text { Organophosphorus } \\
\text { Pesticides }\end{array}$ & $\begin{array}{c}\text { Thiourea } \\
\text { Compounds }\end{array}$ & Sulfide & Perchlorate & $\begin{array}{l}\text { Ethylene } \\
\text { Glycol }\end{array}$ \\
\hline 1 & $5 / 24 / 88$ & Al17 & 0.11 & -- & $\cdots$ & --- & -- & NR & -- & $\ldots$ & --- & -- \\
\hline 1 & $5 / 24 / 88$ & Al18 & $24-36$ & --- & --- & $\cdots$ & $\cdots$ & NR & -- & -- & -- & $\cdots$ \\
\hline 2 & $5 / 24 / 88$ & A119 & $0-12$ & $6 \mathrm{unk} / \mathrm{molsulf} \mathrm{f}^{\mathrm{a}}$ & $\cdots$ & -- & $--\cdot$ & NR & -- & -- & -- & --- \\
\hline 2 & $5 / 24 / 88$ & $\mathrm{~A} 120$ & $24-36$ & 9 unk/molsulf & -- & -- & -- & NR & $\cdots$ & -- & --- & --- \\
\hline 3 & $5 / 25 / 88$ & A121 & 0.10 & $\cdots$ & - & --- & -- &.- & -- & --- & --- & --- \\
\hline 3 & $5 / 25 / 88$ & A122 & $10-22$ & --- & -+ & --- & -.- & --- & --- & $\ldots$ & --- & -- \\
\hline 4 & $5 / 25 / 88$ & A123 & $0-8$ & --- & -- & -- & -- & -- & -- & -- & --- & -- \\
\hline 5 & $5 / 25 / 88$ & A124 & $0-10$ & 1 unk & $\cdots$ & -- & --- & --- & -- & -- & -- & -- \\
\hline 6 & $5 / 26 / 88$ & A125 & $0-12$ & --- & -- & -- & $\cdots$ & -- & -- & -- & $\cdots$ & -- \\
\hline 7 & $5 / 26 / 88$ & A126 & $0-6$ & $5 \mathrm{unk} / \mathrm{molsulf}$ & -- & --- & --- & $\cdots$ & --- & -- & $\ldots$ & --- \\
\hline 8 & $5 / 26 / 88$ & A127 & $0-8$ & $3 \mathrm{unk} / \mathrm{molsulf}$ & --- & --- & +- & --- & -- & $\ldots$ & -- &.-- \\
\hline 9 & $5 / 26 / 88$ & A128 & $0-11$ & 4 unk & $\cdots$ & $\begin{array}{c}\text { ar } 1254^{b} \\
(1.2 \mathrm{ppm})\end{array}$ & $\cdots$ & -- & -- & -- & $\cdots$ & $\cdots$ \\
\hline 9 & $5 / 26 / 88$ & A129 & $12-24$ & 2 unk & --- & $\ldots$ & -- & --- & $\ldots$ & --- & $\cdots$ & -- \\
\hline 10 & $5 / 26 / 88$ & $\mathrm{~A} 130$ & $0-12$ & 7 unk & -- & --- & --- & $\cdots$ & -- & $\ldots$ & $\ldots$ & -- \\
\hline
\end{tabular}

${ }^{\mathrm{a}}$ Unknowns/molybdenum sulfide

barachlor 1254

$---\quad=$ below detection limits.

$\mathrm{NR}=$ Not reported. 


\subsection{REFERENCES}

Barth, D. S. and B. J. Mason, 1984, Soil Sampling Quality Assurance User's Guide, USEPA - 600/4-84-043, U.S. Environmental Protection Agency, Las Vegas, Nevada.

Booth, G. F., 1985, Environmental Protection Manual, RHO-MA-139, Rockwell Hanford Operations, Richland, Washington.

Conklin, A. W., R. E. Elder, W. L. Osborne, J. M. Psarcik, 1982, Rockwell Hanford Operations Environmental Surveillance Annual Report-CY 1981, RHO-HS-SR-82-4 P, Rockwell Hanford Operations, Richland, Washington.

Conklin, A. W., R. E. Elder, W. L. Osborne, 1983, Rockwell Hanford Operations Environmental Surveillance Annual Report-CY-1982, RHO-HS-SR-82-13 P, Rockwell Hanford Operations, Richland, Washington.

Conklin, A. W., R. E. Elder, V. G. Johnson, W. L. Osborne, A. G. Law, 1984, Rockwell Hanford Operations Environmental Surveillance Annual Report-Calendar Year (cy) 1983, RHO-HS-SR-83-REV 1 P, Rockwell Hanford Operations, Richland, Washington.

DeVera, E. R., B. P. Simmons, R. D. Stephens, and D. L. Storm, 1980, Samplers and Sampling Procedures for Hazardous Waste Streams, USEPA-600/2-80-18, U.S. Environmental Protection Agency, Cincinnati, Ohio.

DOE, 1986, USEPA Information Request - Liquid Waste Land Disposal Units, U.S. Department of Energy, Richland Operations Office, Richland, Washington.

DOE-RL, 1989, 2101-M Pond Interim Status Closure Plan, DOE/RL 88-41, U.S. Department of Energy-Richland Operations Office, Richland, Washington.

DOE, 1993, Hanford Site Background: Part 1, Soil Background for Nonradioactive Analytes, DOE/RL-92-24, Rev. 1, U.S. Department of Energy, Richland, Washington.

Elder, R. E., A. W. Conklin, D. D. Brekke, G. W. Egert, and W. L. Osborne, 1986, Rockwell Hanford Operations Environmental Surveillance Annual Report-CY 1985, RHO-HS-SR-85-13-P, Rockwell Hanford Operations, Richland, Washington.

EPA, 1982, Test Methods for Evaluating Solid Waste - Physical/Chemical Methods, 2nd Edition, SW-846, U.S. Environmental Protection Agency, Washington, D.C.

Ford, P. J. P. J. Torina, and D. E. Seely, 1984, Characterization of Hazardous Waste Site -A Methods Manual, Vol. II, Available Sampling Methods, 2nd Edition, USEPA 600/4-84-076, U.S. Environmental Protection Agency, Las Vegas, Nevada. 
Ford, P. J. and P. J. Torina, 1985, Characterization of Hazardous Waste Site -- A Methods Manual, Vol. I, Site Investigations, USEPA/600/4-84/075, U.S. Environmental Protection Agency, Las Vegas, Nevada.

Hembree, N. H., and M. M. Lardy, 1986, Quality Assurance Manual, Rev. 6, UST-RD-QA-7-80, United States Testing Company, Inc., Richland Division, Richland, Washington.

Hembree, N. H., M. M. Lardy, and R. G. Swoboda, 1986, Quality Control Manual, Rev. 3, UST-RD-QA-9-80, United States Testing Company, Inc., Richland Division, Richland, Washington.

Johnson, V. G., 1991, Contaminant Storage and Mixing in Bed Sediment of the Lower Columbia River and Estuary, Supplement to EOS, Transactions, American Geophysical Union, Vol. 72, No. 44.

Landeen, D. S., M. R. Sackschewsky, and S. G. Weiss, 1993, 100 Areas CERCLA Ecological Investigations, WHC-EP-0620, Westinghouse Hanford Company, Richland, Washington.

Maxfield, D., J. M. Rodiquez, M. Buettner, J. Davis, L. Forbes, R. Kovacs, W. Russell, L. Schultz, R. Smith, J. Stanton, and C. W. Wai, 1994, "Heavy Metal Content in the Sediments of the Southern Part of the Coeur d'Alene Lake, Environmental Pollution, Vol. 6, No. 44.

Panesko, J. V., D. E. Bihl, G. F. Booth, R. L. Dirkes, K. Kover, R. E. Wheeler, 1979, Environmental Protection Annual Report - CY-1978, RHO-LD-79-75, Rockwell Hanford Operations, Richland, Washington.

Riley, R. G., R. M. Bean, R. E. Fitzner, D. A. Neitzel, W. H. Richard, 1986, A Preliminary Survey of Polychlorinated Biphenyls (PCBs) in Aquatic Habitats and Great Blue Herons on the Hanford Site, PNL-5685, Pacific Northwest Laboratory, Richland, Washington.

Scott, L. P., G. R. Rao, and R. L. Kolman, 1986, Hazardous Substance Analysis (HSA) Laboratory Quality Control Report for the Period July 1. 1986 through September 30, 1986, United States Testing Company, Inc., Richland Division, Richland, Washington.

Silker, W. B, 1964, "Variations in Elemental Concentrations in the Columbia River, "Limnology and Oceanography, Vol. 9, No. 4, pp. 540-545.

Smith, D. L., 1992, 216-A-29 Ditch Interim Stabilization Final Report, WHC-SD-DD-TI-060, Westinghouse Hanford Company, Richland, Washington.

UST, 1986, Procedure Manual, UST-RD-PM-9-80, United States Testing Company, Inc., Richland, Washington. 
WAC 173-303, "Dangerous Waste Regulations," Washington Administrative Code, as amended.

Wheeler, R. E. and A. G. Law, 1980, Rockwell Hanford Operations Environmental Surveillance Annual Report for Calendar Year 1979, RHO-LD-132, Rockwell Hanford Operations, Richland, Washington.

Wheeler, R. E., A. W. Conklin, R. E. Elder, W. L. Osborne, M. J. Graham, 1981, Environmental Surveillance Annual Report-CY-1980, RHO-LD-163, Rockwell Hanford Operations, Richland, Washington. 
HNF-SD-TWR-TI-005, Rev. 0

This page intentionally left blank. 
HNF-SD-TWR-TI-005, Rev. 0

APPENDIX A

DETAILED QUALITY ASSURANCE INFORMATION FOR ENVIRONMENTAL

SAMPLES ANALYTICAL LABORATORY SERVICES PROVIDED BY

UNITED STATES TESTING, INC.

(From Hembree and Lardy 1986)

A-1 
HNF-SD-TWR-TI-005, Rev. 0

\section{QUALITY ASSURANCE}

\section{A. Basic Program Structure}

The Contractor shall maintain a QA program acceptable to Battelle. The QA requirements shall be identified in an activity QA Manual. The QA Manual shall contain procedures for implementation of the QA requirements and sha 11 be maintained current.

B. Organizational Structure and Responsibilities

The Contractor shall provide a chart or diagram illustrating the organization structure applied to this service activity and the relationship of the Quaity Assurance Office (QAO) to the service activity staff.

A manager with the overall responsibility for implementing the QA requirements shail be identified in the QA Manual. The $Q A$ organization shall be administratively independent of analytical operations with separate reporting channels.

C. Specific QA Requirements

The following specific QA requirements shall be included in the Contractor's QA Manual:

1. Procurement - The procurement activity shall be planned and performed in a controlled and documentable manner.

Procurement and subcontract requirements will be reviewed, the appropriate QA requirements applied, and the relevant items and services inspected to assure that procured items and services are suitable for their intended use.

2. Written Procedures - Written procedures shall be developed and implemented to controi activities that could have a significant impact on the accuracy or validaty of data.

Preparation, identification, and use of such procedures shall be controlled for critical steps or tests in the analytical process. Procedures shal 7 be reviewed and revised as needed on a periodic basis, as stated in the QA Manual.

Interferences shall be identified in the written procedure for each method. Procedures shall include the steps (precautions) taken to minimize the effect of interferences on performance criteria specified in this Statement of Work.

3. Document Control - Documents containing information that could have a significant impact upon quality (i.e., written procedures) shail be reviewed, identified, approved, updated, and distributed in a controlled manner. 
4. Material Identification and Control - Positive identification and control measures shall be used to assure that samples and other critical items are identifiable at all stages of the analysis and traceable to their source and the resultant data.

5. Control of Measuring and Test Equipment - Measuring and test equipment shall be controlled and calibrated to assure the accuracy and reliability of required data. Relatability to the National Bureau of Standard or other recognized standards agencies shall be maintained.

6. Nonconformances and Corrective Action - Nonconforming materials, components or parts (including samples and data) shall be reported, controlled, and dispositioned in accordance with procedures in the QA Manual. A description of the corrective actions shall be included.

7. Quality Assurance Records - Evidence that $Q A$ and $Q C$ activities were performed shall be documented, reported to Battelle as requested, and preserved.

8. Quality Assurance Audits - The Contractor shall maintain a formal QA audit program. In addition, Contractor actfvity shall be subject to periodic routine audits scheduled approximately semiannually by Battelle. In addition, special or nonroutine audits may be scheduled by Battelle on an as-needed basis.

\section{o. Training}

Staff shall receive QA training appropriate to their participation. Training shall be performed as necessary to assure that each staff member understands the QA and technical requirements applicable to their work. All training, whether specific to $Q A$ or in other areas related to the work, shall be documented and accurate records kept.

E. Quality Control

The Contractor shall assure the integrity and validity of data through implementation of an internal quality control program. The program shall include the analysis of replicate, blank and spiked samples. A system of reviewing and analyzing the results of these samples shall be maintajned to detect current problems due to contamination, calibration, calculations, inadequate procedures, or other causes. Standard methods shall be used whenever possible and methods that are developed or adapted shall be tested and completely documented. All methods and method changes shall be approved by Battelle. 
The Contractor shall assure that facilities and equipment ar constructed and operated to emphasize radiological control to minimize the possibility of cross-contamination.

The internal quality control system shall be described in a written procedure(s) and shall include a corrective action system for discrepant results. In addition, the measuring and test equipment (including the DOE-owned Hanford External Dosimetry (TLD) System) will be calibrated and traceable to the data obtained by each unit of measuring and test equipment.

The Contractor shall provide routine reports informal to Battelle, within 30 business days of completion of each quarter, which describe the current status and results of ongoing $Q C$ evaluations for each service area. In addition, results of the $Q C$ program shall be formally reported to Battelle on an annual basis, within 30 business days after the completion of the operational year, which will include a summary of analytical results on standard samples, an evaluation of the status of the analytical procedures, and a description of any corrective actions taken to solve problems that have been identified.

\section{F. Software Activities}

1. Software Documentation - Each computer program that is a part of a software system and capable of being tested and evaluated independently of that system shall be separately documented prior to release for use. The point in the development of the software at which documentation is required and the minimum documentation requirements shall be established.

2. Software Testing - Verification of the computer code shall be established using data for which the correct result is known. The verification process shall be documented as proof it was performed and for future reference.

3. Software Control - Methods shall be established to help ensure that computer software changes are properly controlled and approved. Computer programs shall be identified using unique serial revision numbers.

4. Computer Program Certification and Validation - Computer programs shall be validated for adequacy to meet technical requirements of the task. The validity shall be documented.

5. Security of Software - Methods shall be established to help ensure the security of the software (i.e., help avoid unauthorized use and changes).

6. Error Control - Methods shall be developed to evaluate, control, and correct data-entry errors. 
G. Intercomparisons and Audits

The Contractor shall provide reasonable access to all facilities and data for the purpose of verification of performance and to ensure that the conditions of this Statement of Work are being met. Battelle may submit blind or other audit samples to determine compliance with accuracy and precision requirements. Participation in the DOE Quality Assessment Program is mandatory. The Contractor shall also maintain its EPA Safe Drinking Water Act certification for measurement of radionuclides. The Contractor shall continue to participate in the EPA Environmental Radioactivity Laboratory Intercomparison Studies Program and report UST results, known values, and explanations of results outside limits to Battelle within 30 business days following the end of each calendar quarter. Battelle may also require participation in other intercomparison programs. 
VII. HAZARDOUS CHEMICAL ANALYTICAL SUPPORT SERVICES (TaSK IV)

\section{A. Services Required}

In support of Hanford Environmental Surveillance Programs, the Contractor shall perform routine analysis of groundwater, surface water, soil, and process samples for the parameters and substances listed in table VII-1.

The Contractor shall perform the specified chemical analyses on groundwater, surface water, soil, or process samples that may contain

low levels of radioactive materials (generally at concentrations less than those specified in DOE Order $5480.1 \mathrm{~A}$ as releasable to the environment). Routine samples constitute the bulk of the total and will be delivered to the Contractor during normal business hours in accordance with a schedule established by Battelle. Samples may also be delivered by other Hanford rout ine service customers.

The Contractor shall possess all capabilities and equipment necessary to receive, prepare, and analyze samples which contain both radioactive and hazardous chemical substances. The Contractor may often be required to perform several different analyses on a single sample.

The Contract shall add preservatives to sampie collection containers as required by the analytical procedures. In accordance with the sampling schedule established by Battelie, the Contractor will be provided pre-cleaned (EPA approved) sample collection containers, for each week's sampling, 3 weeks prior to sample collection. Containers shall have been prepared and be available to Battelle 1 week prior to scheduled sample collection.

The samples to be analyzed by the Contractor may contain potentially hazardous organic and/or inorganic materials. It is the Contractor's responsibility to take all actions necessary to ensure his employee's safety.

B. Characteristics and Mandling of Samples

The following are descriptions of samples:

1. Groundwater and Surface Water - Samples are water collected from wells or surface water bodies for radiological and. chemical analyses. Samples may contain concentrations of tritium, other radioactive substances, or nitrate ion comparable with current levels found within Hanford groundwater. 
2. Process Liquids - Water samples and liquids are collected from process streams, effluent ditches, trenches, pond, and cribs. Samples may contain concentrations of radioactivity at levels somewhat higher than found in groundwater samples.

3. Soil - Samples of surface or subsurface soil, sediments, sand and gravel. Samples may contain levels of radioactivity somewhat higher than found in ground water samples.

4. Nonroutine Samples - Nonroutine samples may be submitted as dictated by program needs and may require rapid or priority analysis. Samples will generally fit into one of the media categories given above, but may differ from routine samples in size, appearance, or matrix and may contain higher than routine levels of radioactive or chemical substances.

Routine samples will be delivered to the Contractor during normal business hours in appropriate containers based on the anaiys is to be performed. Some samples may require subsampling by the Contractor, and subsequent preservation and storage in accordance with the appropriate individual analytical procedures.

All analyses shall be performed within the maximum holding times prescribed by the approved analytical procedures.

\section{Workload}

The Contractor shall have the capability to perform hazardous chemical analytical tests within the minimums and maximums specified in ARTICLE IV - INDEFINITE QUANTITY AND ORDERING OF SERVICES, of the contract schedule.

D. Analytical Requirements

1. Normal Analyses - Required capabilities for normal analyses are listed in table VII-1.

Analytical procedures and equipment shall be those in Test Methods for Evaluating Solid Wastes--Physical and Chemical Methods, SW-846, Second Edition. Procedures not available in SW-846 shall be those in Standard Methods for the Examination of Water and Wastewater, Sixteenth Edition, (1985).

Other procedures may be used with prior Battelle approval provided the procedures are clearly documented by the Contractor prior to implementation. Contractor sha 11 test the accuracy and effectiveness of these procedures through the performance of $Q C$ analyses. The results of the QC analyses shall be made available upon request to Battelle. 
All procedures (including chain-of-custody) shall be compiled in a procedures manual that is maintained current and documents all approvals. All method and equipment changes shall be reviewed and approved by Battelle prior to implementation.

The Contractor shall maintain a computerized MS Tibrary search system capable of providing a forward comparison, utilizing the standard spectra contained in the EPA/NIH Mass Spectral Data Base. The most recent available EPA/NIH library shall be used.

The specific analytical requirements listed in table VII-1 include screening analyses for the list of Dangerous Waste Constituents contained in Washington Administrative Code (WAC) 173-303-9905 (Attachment 1).

2. Priority Analyses - Analytical procedures for priority analyses shall be the same as those for normal analyses. The only difference is expedited processing and reporting.

3. Rapid Anaiyses - Analytical procedures for rapid analyses of environmental or process samples shali be the same as those for normal analyses except that results shall be reported within 24 hrs from receipt of sample, or upon completion of the requested analysis consistent with procedural or equipment limitations. The Contractor shall contact Battelle or the designated customer representative prior to diluting and reanalyzing samples submitted and analyzed on a rapid basis. The customer will designate the processing category (normal, priority, or rapid) appropriate for the dilution and reanalysis. Rapid analys is capabilities may be continuously required over a 30-day period.

\section{E. Performance Criteria}

Analytical performance sha 11 meet the requirement detailed in SW-846, Second Edition for analytical laboratories and for the performance of specific procedures.

The Contractor sha 1$\}$ have written quality assurance and quaity control procedures and shal 1 conduct laboratory operations to the QA/QC criteria documented in SW-846, Second Edition and Handbook for Analytical $O C$ in Water and Wastewater Laboratories, EPA-600/4-79-019 (1979). Documentation of QC evaluations shall be sufficient to verify the acceptability of laboratory operations and analytical performance.

The QA requirements detailed in Section VI, Quality Assurance, of this Statement of Work, shall apply to the Hazardous Chemical Analytical Support Services. 
The quality control procedures for hazardous chemical analyses shall include (as appropriate to each analysis) evaluation of blanks, random matrix spikes (for $10 \%$ of samples), internal standards, surrogates, and standard calibration curves. Specific quality control procedures for individual methods shall be detailed in the Contractor's documented analytical procedures.

The Contractor shall comply with its written procedures for sample chain-of-custody and document control.

\section{F. Reporting and Communication}

1. Analytical Results - Reporting times for all normal analyses of water and process 1 iquid samples sha 11 be 25 business days from receipt of the sample and analytical request at the Contractor's laboratory. Reporting time for all normal analyses of soil samples shall be 35 business days. Priority anaiyses results for all sample media shall be reported within 10 business days from receipt of the sample. Priority results may be reported by telephone, but must be confirmed in writing with the next routine data transmittal to the customer. Rapid analys is results for all sample media shall be reported within 24 hours from receipt of the sample or upon completion of the requested analys is consistent with procedural and other equipment limitations. Rapid results may be reported by telephone, but must be confirmed in writing with the next routine data transmittal.

2. Immediate Notification - The Contractor shall immediately (COB) notify Battelle by telephone of lost samples, invalid results, or the loss of. a capabilities which may adversely affect the analytical results. Written confirmation shall be provided to Battelle with the next routine data transmittal.

3. Report Format and Content - Results shall be stated in the units listed in table VII-1. Reports of results shall consist of both printed report and electronic data processing tapes. Report formats shall be compatible with Battelle electronic data processing system. The following information shall be reported for each andysis:

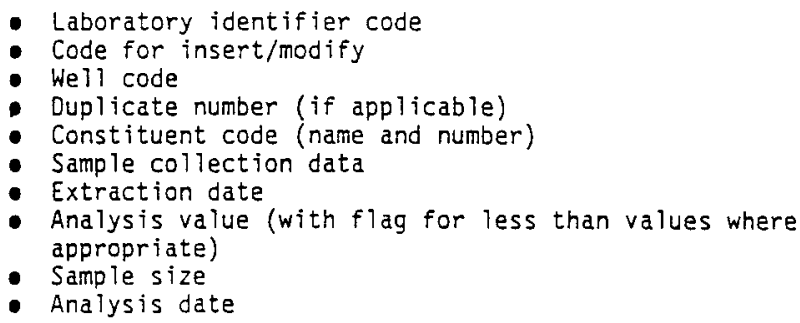


- UST number

- Report date

- Number of dilutions

- Confirmation (if applicable)

- Comments

Other reporting formats may be used with prior Battelle approval. Reports shall be transmitted to the customer submitting the sample $(s)$.

G. Sample Archives

The Contractor shall preserve and maintain identification on all unused portions of samples and any final analytical preparations with which measurements are made for at least 4 weeks following the final reporting of the complete results. Prior to final disposition the Contract shall request the authorized customer representative for authorization to dispose of above.

The Contractor shall maintain records of all data relative to sample analyses including raw, intermediate, final data and results in accordance with the General Requirements of this Statement of Work.

The Contractor shall assure the integrity and security of all samples (initial and unused portions), sample extracts and other preparations, and analytical data and results. 
HNF-SD-TWR-TI-005, Rev. 0

TABLE VII-1

Analytical Requirements for Normal and Priority Hazardous Chemical Analyses of Environmental and Process Samples. (sheet 1 of 6 )

\begin{tabular}{|c|c|c|c|c|}
\hline \multirow{2}{*}{ SUBSTANCE } & \multicolumn{2}{|c|}{ MDC } & \multicolumn{2}{|c|}{ SAMPLE SIZE } \\
\hline & WATER & - SOIL & WATER & SOIL \\
\hline BARIUM & $6 \mu g / L$ & $0.5 \mu g / g$ & & \\
\hline CADMIUM & $2 \mu \mathrm{g} / \mathrm{L}$ & $0.2 \mu \mathrm{g} / \mathrm{g}$ & & \\
\hline CHROMIUM & $10 \mu \mathrm{g} / \mathrm{L}$ & $1 \mu \mathrm{g} / \mathrm{g}$ & & \\
\hline SILVER & $10 \mu \mathrm{g} / \mathrm{L}$ & $1 \mu g / g$ & & \\
\hline COPPER & $10 \mu g / \mathrm{L}$ & $1 \mu g / g$ & & \\
\hline MANGANESE & $5 \mu \mathrm{g} / \mathrm{L}$ & $0.5 \times g / g$ & & \\
\hline SODIUM & $100 \mathrm{Hg} / \mathrm{L}$ & $10 \mu \mathrm{g} / \mathrm{g}$ & & $10 \mathrm{~g}$ \\
\hline NICKEL & $10 \mu \mathrm{g} / \mathrm{h}$ & $1 \mu g / 9$ & & \\
\hline VANADIUM & $5 \mu \mathrm{g} / \mathrm{L}$ & $0.5 \mu g / g$ & & \\
\hline ALUMINUM & $150 \mathrm{~kg} / \mathrm{L}$ & $15 \mu g / g$ & & \\
\hline POTASSIUM & $100 \mu \mathrm{g} / \mathrm{L}$ & $10 \mu \mathrm{g} / \mathrm{g}$ & IL & \\
\hline IRON & $50 \mu \mathrm{g} / \mathrm{L}$ & $5 \mu g / g$ & & \\
\hline MAGNESIUM & $50 \mu \mathrm{g} / \mathrm{L}$ & $5 \mu g / g$ & & \\
\hline CALCIUM & $50 \mu \mathrm{g} / \mathrm{L}$ & $5 \mu g / g$ & & \\
\hline ZINC & $5 \mu \mathrm{g} / \mathrm{L}$ & $0.5 \mu \mathrm{g} / \mathrm{g}$ & & \\
\hline THALLIUM & $10 \mathrm{ppb}$ & $1.0 \mu \mathrm{g} / \mathrm{g}$ & & $10 \mathrm{~g}$ \\
\hline LEAD & $5 \mu g / L$ & $0.5 \mu \mathrm{g} / \mathrm{g}$ & & $10 \mathrm{~g}$ \\
\hline MERCURY & $0.1 \mu \mathrm{g} / \mathrm{L}$ & $0.1 \mathrm{\mu g} / \mathrm{g}$ & $500 \mathrm{~mL}$ & $10 \mathrm{~g}$ \\
\hline SELENIUM & $5 \mu g / h$ & $0.5 \mu \mathrm{g} / \mathrm{g}$ & & \\
\hline & & & $1 \mathrm{~L}$ & $10 \mathrm{~g}$ \\
\hline ARSENIC & $5 \mu g / L$ & $0.5 \mu \mathrm{g} / \mathrm{g}$ & & \\
\hline ENDRIṆ & $1 \mathrm{ppb}$ & $1.0 \mu \mathrm{g} / \mathrm{g}$ & & \\
\hline LINDANE & I ppo & $1.0 \mu \mathrm{g} / \mathrm{g}$ & $2 L$ & $50 \mathrm{~g}$ \\
\hline METHOXYCLOR & $1 \mathrm{ppb}$ & $1.0 \mu \mathrm{g} / \mathrm{g}$ & & \\
\hline TOXAPHENE & I ppo & $1.0 \mathrm{\mu g} / \mathrm{g}$ & & \\
\hline POLYCHLORINATED BIPHENYLS & $1 \mathrm{ppb}$ & $1.0 \mu \mathrm{g} / \mathrm{g}$ & $2 \mathrm{~L}$ & $50 \mathrm{~g}$ \\
\hline
\end{tabular}


HNF-SD-TWR-TI-005, Rev. 0

TABLE VII-1

Analytical Requirements for Normal and Priority Hazardous Chemical Analyses of Environmental and Process Samples. (sheet 2 of 6 )

\begin{tabular}{|c|c|c|c|c|}
\hline \multirow{2}{*}{ SUBSTANCE } & \multicolumn{2}{|c|}{ MDC } & \multicolumn{2}{|c|}{ SAMPLE SIZE } \\
\hline & WATER & SOIL & WATER & SOIL \\
\hline $2,4-D$ & $1 \mathrm{ppb}$ & $1 \mu g / g$ & & \\
\hline 2,4,5-TP SILVEX & $i p p b$ & $1 \mu g / g$ & $2 \mathrm{~L}$ & $200 \mathrm{~g}$ \\
\hline CARBOPHENOTHION & $2 \mathrm{ppb}$ & $1 \mu g / g$ & & \\
\hline DISULFOTON & $2 \mathrm{ppb}$ & $1 \mu g / g$ & & \\
\hline DIMETHOATE & $5 \mathrm{ppb}$ & $1 \mu g / g$ & & \\
\hline METHYLPARATHION & $2 \mathrm{ppb}$ & $i \mu g / g$ & $2 \mathrm{~L}$ & $50 \mathrm{~g}$ \\
\hline PARATHION & $2 p p b$ & $1 \mu g / g$ & & \\
\hline TETRAETHYLPYROPHOSPHATE & $2 \mathrm{ppb}$ & $1 \mu g / g$ & & \\
\hline TETRACHLOROMETHANE & $10 \mathrm{ppb}$ & $0.01 \mu \mathrm{g} / \mathrm{g}(\mathrm{a})$ & & \\
\hline METHYLETHYL KETONE & $10 \mathrm{ppb}$ & $0.01 \mu \mathrm{g} / \mathrm{g}$ & & \\
\hline 1,1,1-TRICHLOROETHANE & $10 \mathrm{ppb}$ & $0.01 \mu \mathrm{g} / \mathrm{g}$ & & \\
\hline 1,1,2-TRICHLOROEHTANE & $10 \mathrm{ppb}$ & $0.01 \mu \mathrm{g} / \mathrm{g}$ & $40 \mathrm{~mL}$ & $\log$ \\
\hline 1,1,2-TRICHLOROETHYLENE & $10 \mathrm{ppb}$ & $0.01 \mu \mathrm{g} / \mathrm{g}$ & & . \\
\hline PERCHLOROETHYLENE & $10 \mathrm{ppb}$ & $0.01 \mu \mathrm{g} / \mathrm{g}$ & & \\
\hline XYLENE & $10 \mathrm{ppb}$ & $0.01 \mu \mathrm{g} / \mathrm{g}$ & & \\
\hline CHLOROFORM & $10 \mathrm{ppb}$ & $0.01 \mu \mathrm{g} / \mathrm{g}$ & & \\
\hline METHYLENE CHLORIDE & $10 \mathrm{ppb}$ & $0.01 \mu \mathrm{g} / \mathrm{g}$ & & \\
\hline HEXACHLOROPHENE & 10 ppt & $1 \mu g / g$ & & \\
\hline NAPTHALENE & $10 \mathrm{ppb}$ & $1 \mu \mathrm{g} / \mathrm{g}$ & & \\
\hline PHENOL & $10 p p b$ & . $1 \mu g / g$ & $2 \mathrm{~L}$ & $50 \mathrm{~g}$ \\
\hline CHLORINATED BENZENES & $10 \mathrm{ppb}$ & $i \mu g / g$ & & \\
\hline KEROSENE & $10 \mathrm{ppm}$ & $1000 \mu \mathrm{g} / \mathrm{g}$ & . & \\
\hline HYDRAZINE & $30 \mathrm{ppb}$ & & & \\
\hline PHENOL & $10 \mathrm{ppb}$ & $1 \mu g / g$ & $2 \mathrm{~L}$ & $50 \mathrm{~g}$ \\
\hline DIRECT AQUEOUS INJECTION(b) & $3 \mathrm{ppm}$ & $10 \mu g / g$ & $40 \mathrm{~mL}$ & $50 \mathrm{~g}$ \\
\hline GCMS ANALYSES & & & & \\
\hline
\end{tabular}


HNF-SD-TWR-TI-005, Rev. 0

Tabie VII-1

Analytical Requirements for Norma 1 and Priority Hazardous Chemical Analyses of Environmental and Process Samples. (sheet 3 of 5 )

\begin{tabular}{|c|c|c|c|c|}
\hline \multirow{2}{*}{ SUBSTANCE } & \multicolumn{2}{|r|}{ MDC } & \multicolumn{2}{|c|}{ SAMPLE SIZE } \\
\hline & WATER & SOIL & WATER & SOIL \\
\hline THIOUREA & $200 \mathrm{ppb}$ & $2 \mu g / 9$ & $40 \mathrm{~mL}$ & $50 \mathrm{~g}$ \\
\hline CITRUS RED \#2 & $1 \mathrm{ppm}$ & $10 \mu g / g$ & $50 \mathrm{~mL}$ & $50 \mathrm{~g}$ \\
\hline CYANIOE & $10 \mathrm{ppb}$ & $1 \mu \mathrm{g} / \mathrm{g}$ & $2 L$ & $50 \mathrm{~g}$ \\
\hline $010 \times 1 \mathrm{~N}$ & $0.1 \mathrm{ppb}$ & $0.0002 \mu \mathrm{g} / \mathrm{g}$ & $1 \mathrm{~L}$ & $50 \mathrm{~g}$ \\
\hline TOX ( 2 samples req.) & $100 \mathrm{ppb}$ & & $250 \mathrm{~mL}$ & $\begin{array}{c}\text { (each } \\
\text { sample) }\end{array}$ \\
\hline TOX (2 samples req.) & $20 \mathrm{ppb}$ & & $250 \mathrm{~mL}$ & $\begin{array}{c}\text { (each } \\
\text { sample) }\end{array}$ \\
\hline TOC & $1 \mathrm{ppm}$ & $10 \mathrm{Hg} / \mathrm{g}$ & $750 \mathrm{~mL}$ & \\
\hline EOX & & $1 \mu g / g$ & & $10^{\circ}$ \\
\hline TOTAL CARBON (TC) & $1 \mathrm{ppm}$ & $10 \mu \mathrm{g} / \mathrm{g}$ & $750 \mathrm{~mL}$ & $50 \mathrm{~g}$ \\
\hline NITRATE & $500 \mathrm{ppb}$ & $1 \mu g / g$ & & \\
\hline SULFATE & $500 \mathrm{ppb}$ & $1 \mu \mathrm{g} / \mathrm{g}$ & & \\
\hline FLUORIDE & 500 ppb & $1 \mu \mathrm{g} / \mathrm{g}$ & $125 \mathrm{~mL}$ & 509 \\
\hline CHLORIDE & $500 \mathrm{ppb}$ & $1 \mu g / g$ & & \\
\hline PHOSPHATE & $1 p p b$ & $2 \mu g / g$ & & \\
\hline SULFIDE & $1 \mathrm{ppm}$ & $10 \mu g / g$ & $1 \mathrm{~L}$ & $50 \mathrm{~g}$ \\
\hline PERCHLORATE & $\mathrm{ippm}$ & $2 \mu g / g$ & $125 \mathrm{~mL}$ & $50 \mathrm{~g}$ \\
\hline AMMONIUM ION & $50 \mathrm{ppb}$ & $0.5 \mu \mathrm{g} / \mathrm{g}$ & $350 \mathrm{~mL}$ & $50 \mathrm{~g}$ \\
\hline ETHYLENE GLYCOL & $10 \mathrm{ppm}$ & $10 \mu g / g$ & $50 \mathrm{~mL}$ & $50 \mathrm{~g}$ \\
\hline $\begin{array}{l}\text { COLIFORM BACTERIA (d) } \\
\text { (2 water sample req.) }\end{array}$ & $2.2 \mathrm{mpn}$ & $2.2 \mathrm{mpn}$ & $\begin{array}{c}100 \mathrm{ml} \\
\text { (each } \\
\text { sample) }\end{array}$ & $50 \mathrm{~g}$ \\
\hline
\end{tabular}

PSTE7.3272.V.1 
Table VII-1

Analytical Requirements for Normal and Priority Hazardous Chemical Analyses of Environmental and Process Samples. (sheet 4 of 6)

\begin{tabular}{|l|c|c|c|c|}
\hline \multirow{2}{*}{ SUBSTANCE } & \multicolumn{2}{|c|}{ MDC } & \multicolumn{2}{c|}{ SAMPLE SIZE } \\
\cline { 2 - 5 } & WATER & SOIL & WATER & SOIL \\
\hline TOTAL DISSOLVED SOLIDS(TOS) & $5 \mathrm{ppm}$ & & $100 \mathrm{~mL}$ & \\
(2 SAMPles req.) & $1 \mathrm{pCi} / \mathrm{L}$ & $1 \mathrm{pCi} / \mathrm{g}$ & $1 \mathrm{~L}$ & $50 \mathrm{~g}$ \\
RADIUM & $4 \mathrm{pCi} / \mathrm{L}$ & $6 \mathrm{pCi} / \mathrm{g}$ & $1 \mathrm{~L}$ & $5 \mathrm{~g}$ \\
GROSS ALPHA & $8 \mathrm{pCi} / \mathrm{L}$ & $3 \mathrm{pCi} / \mathrm{g}$ & $1 \mathrm{~L}$ & $5 \mathrm{~g}$ \\
\hline
\end{tabular}

..........ENHANCED ANALYSES FOR 9905 EVALUATIONS(C)..........

\begin{tabular}{|c|c|c|c|c|}
\hline BARIUM & $6 \mu g / L$ & $0.6 \mathrm{Ng} / \mathrm{g}$ & & \\
\hline CADMIUM & $2 \mu \mathrm{g} / \mathrm{L}$ & $0.2 \mathrm{Lg} / \mathrm{g}$ & & \\
\hline CHROMIUM & $10 \mu g / L$ & $1 \mu g / g$ & & \\
\hline SILVER & $10 \mu \mathrm{g} / \mathrm{L}$ & $1 \mu \mathrm{g} / \mathrm{g}$ & & \\
\hline COPPER & $10 \mu \mathrm{g} / \mathrm{L}$ & $1 \mu g / g$ & & \\
\hline MANGANESE & $5 \leftarrow 9 / L$ & $0.5 \mu \mathrm{g} / \mathrm{g}$ & & \\
\hline SODIUM & $100 \mu \mathrm{g} / \mathrm{h}$ & $10 \mu \mathrm{g} / \mathrm{g}$ & & \\
\hline NICKEL & $10 \mu g / L$ & $1 \mu g / g$ & & \\
\hline VANADIUM & $5 \Perp g / L$ & $0.5 \mu \mathrm{g} / \mathrm{g}$ & $1 \mathrm{~L}$ & $10 \mathrm{~g}$ \\
\hline ANTIMONY & $100 \mu \mathrm{g} / \mathrm{L}$ & $10 \mathrm{ng} / \mathrm{g} \cdot$ & & \\
\hline ALUMINUM & $150 \mu g / L$ & $15 \mu g / 9$ & & \\
\hline POTASSIUM & $100 \mu g / L$ & $10 \mu \mathrm{g} / \mathrm{g}$ & & \\
\hline IRON & $50 \mu \mathrm{g} / \mathrm{L}$ & $5 \mu g / g$ & & \\
\hline MAGNESIUM & $50 \mu g / L$ & $5 \mu g / g$ & & \\
\hline BERYLLIUM & $5 \mu \mathrm{g} / \mathrm{L}$ & $0.5 \mu \mathrm{g} / \mathrm{g}$ & & \\
\hline CALCIUM & $50 \mu \mathrm{g} / \mathrm{L}$ & - $5 \mu g / g$ & & \\
\hline ZINC & $5 \mathrm{Hg} / \mathrm{L}$ & $0.5 \mu \mathrm{g} / \mathrm{g}$ & & \\
\hline OSMIUM & $300 \mathrm{sg} / \mathrm{L}$ & $30 \mu \mathrm{g} / \mathrm{g}$ & & \\
\hline STRONTIUM & $300 \mu \mathrm{g} / \mathrm{L}$ & $30 \mu \mathrm{g} / \mathrm{g}$ & & \\
\hline THIOUREA . & $200 \mathrm{ppb}$ & $2 \mu g / g$ & & \\
\hline 1-ACETHYL-2-THIOUREA & $200 \mathrm{ppb}$ & $2 \mu g / g$ & & \\
\hline 1-(O-CHLOROPHYNEL)THIOUREA & $200 \mathrm{ppb}$ & $2 \mu g / g$ & & \\
\hline OIETHYLSTILBESTEROL & $200 \mathrm{ppb}$ & $2 \mu g / g$ & & \\
\hline ETHYLENETHIOUREA & $200 p p b$ & $2 \mu g / g$ & $40 \mathrm{~mL}$ & $50 \mathrm{~g}$ \\
\hline
\end{tabular}

05787.3272 .4 .1 
HNF-SD-TWR-TI-005, Rev. 0

Table VII-1

Analytical Requirements for Normal and Priority Hazardous Chemical Analyses of Environmental and Process Samples. (sheet 5 of 6)

\begin{tabular}{|c|c|c|c|c|}
\hline \multirow{2}{*}{ SUBSTANCE } & \multicolumn{2}{|c|}{$M D C$} & \multicolumn{2}{|c|}{ SAMPLE SIZE } \\
\hline & WATER & SOIL & WATER & SOIL \\
\hline 1-NAPTHYL-2-THIOUREA & $200 \mathrm{ppb}$ & $2 \mu g / g$ & & \\
\hline N-PHENYLTHIOUREA & $200 \mathrm{ppb}$ & $2 \mu g / g$ & & \\
\hline ENDRIN & $1 \mathrm{ppb}$ & $1 \mu g / g$ & & \\
\hline LINDANE (and isomers) & $i p p b$ & $1 \mu g / g$ & & \\
\hline METHOXYCLOR & $1 p p b$ & $1 \mu g / g$ & & \\
\hline TOXAPHENE & $1 \mathrm{ppb}$ & $1 \mu \mathrm{g} / \mathrm{g}$ & & \\
\hline ALDRIN & 1 ppo & $1 \mu g / g$ & & \\
\hline CHLORDANE & $1 \mathrm{ppb}$ & $1 \mu g / g$ & & \\
\hline $4,4^{\prime}-D 00$ & $1 \mathrm{ppb}$ & $1 \mu g / g$ & & \\
\hline $4,4^{\prime}-D D E$ & i ppb & $1 \mu g / g$ & $2 \mathrm{~L}$ & $50 \mathrm{~g}$ \\
\hline $4,4^{\prime}-$ DOT & 1 ppo & $1 \mu \mathrm{g} / \mathrm{g}$ & & \\
\hline ENDOSULFAN & $1 \mathrm{ppb}$ & $1 \mu g / g$ & & \\
\hline HEPTACHLOR & $1 \mathrm{ppb}$ & $1 \mu g / 9$ & & \\
\hline HEPTACHLOR EPOXIDE & $1 \mathrm{ppb}$ & $1 \mu g / g$ & & \\
\hline KEPONE & lppb & $1 \nu g / g$ & & \\
\hline DIELDRIN & 1 ppb & $1 \nu g / g$ & & \\
\hline CHLOROBENZILATE & $100 \mathrm{ppb}$ & $10 \mu \mathrm{g} / \mathrm{g}$ & & \\
\hline $2,4-D$ & $i p p b$ & $1 \mu g / g$ & & \\
\hline 2,4,5-TP SILVEX & $1 \mathrm{ppb}$ & $1 \mu g / g$ & $2 L$ & $200 \mathrm{~g}$ \\
\hline $2,4,5-T$ & $1 \mathrm{ppb}$ & $1 \mu g / g$ & & \\
\hline TETRACHLOROMETHANE & $10 \mathrm{ppb}$ & $0.01 \mu g^{\prime} / g^{(a)}$ & & \\
\hline BENZENE & $10 \mathrm{ppb}$ & $0.01 \mu \mathrm{g} / \mathrm{g}$ & & \\
\hline DIOXANE & $500 \mathrm{ppb}$ & $0.5 \mathrm{ug} / \mathrm{g}$ & & \\
\hline METHYLETHYL KETONE & $10 \mathrm{ppb}$ & $0.01 \mu \mathrm{g} / \mathrm{g}$ & & \\
\hline PYRIDINE & S00 ppb & $0.5 \mu \mathrm{g} / \mathrm{g}$ & & \\
\hline TOLUENE & $10 \mathrm{ppb}$ & $0.01 \mu \mathrm{g} / \mathrm{g}$ & $40 \mathrm{~mL}$ & $10 \mathrm{~g}$ \\
\hline 1,1,1-TRICHLOROETHANE & $10 \mathrm{ppb}$ & $0.01 \mu \mathrm{g} / \mathrm{g}$ & & \\
\hline 1,1,2-TRICHLOROETHANE & $10 \mathrm{ppb}$ & $0.01 \mathrm{~kg} / \mathrm{g}$ & & \\
\hline 1,1,2-TRICHLOROTHEYLENE & $10 \mathrm{ppb}$ & $0.01 \mu \mathrm{g} / \mathrm{g}$ & & \\
\hline
\end{tabular}


Iable VII-1

Anaiytical Requirements for Normal and Priority Hazardous Chemical Analyses of Environmental and Process Samples. (sheet 6 of 6 )

\begin{tabular}{|l|c|c|c|c|}
\hline \multirow{2}{*}{ SUBSTANCE } & \multicolumn{2}{c|}{ MDC } & \multicolumn{2}{c|}{ SAMPLESIZE } \\
\cline { 2 - 5 } & WATER & SOIL & WATER & SOIL \\
\hline PERCHLOROETHYLENE & $10 \mathrm{ppb}$ & $0.01 \mu \mathrm{g} / \mathrm{g}$ & & \\
XYLENE & $10 \mathrm{ppb}$ & $0.01 \mu \mathrm{g} / \mathrm{g}$ & & \\
FORMALDEHYDE & $500 \mathrm{ppb}$ & $0.5 \mu \mathrm{g} / \mathrm{g}$ & & \\
ADOITIONAL 9905 VOAS(b) & $10 \mathrm{ppb}$ & $0.01 \mu \mathrm{g} / \mathrm{g}$ & & \\
& & & & \\
HEXACHLOROPHENE & $10 \mathrm{ppb}$ & $1 \mu \mathrm{g} / \mathrm{g}$ & & \\
NAPTHALENE & $10 \mathrm{ppb}$ & $1 \mu \mathrm{g} / \mathrm{g}$ & & \\
PHENOL & $10 \mathrm{ppb}$ & $1 \mu \mathrm{g} / \mathrm{g}$ & $2 \mathrm{~L}$ & $50 \mathrm{G}$ \\
CHLORINATEO BENZENES & $10 \mathrm{ppb}$ & $1 \mu \mathrm{g} / \mathrm{g}$ & & \\
STRYCHNINE & $50 \mathrm{ppb}$ & $5 \mu \mathrm{g} / \mathrm{g}$ & & \\
MALEICHYDRAZINE & $500 \mathrm{ppb}$ & $50 \mu \mathrm{g} / \mathrm{g}$ & & \\
NICOTINIC ACID & $100 \mathrm{ppb}$ & $10 \mu \mathrm{g} / \mathrm{g}$ & & \\
KEROSENE & $10 \mathrm{ppm}$ & $1000 \mu \mathrm{g} / \mathrm{g}$ & & \\
ADDITIONAL 9905 ABNS(b) & $10 \mathrm{ppb}$ & $1 \mu \mathrm{g} / \mathrm{g}$ & & \\
\hline
\end{tabular}

P5787.3272.V-1

(a) MDC will be reudced when samples contain high levels of interfering organics and dilution is necessary. MDC is reduced in direct proportion to dilution.

(b) See Table VII-2.

(c) Substances indicated in italics represent analytical enhancement, of existing analysis, for 9905 evaluation.

(d) Coliform analyses are performed in accordance with procedures contained in "Standards Methods for Examination of Water and Waste Water," Edition 1985. Procedure calls for five tubes, each containing replicate $10 \mathrm{~mL}$ portions of sample, to be tested. When none of the tubes test positive, the value is reported as $<2.2$ MPN. 
HNF-SD-TWR-TI-005, Rev. 0

APPENDIX B

DETAILED SUMMARY OF THE DANGEROUS WASTE CONSTITUENTS

IDENTIFIED IN WAC-173-303-9905 BY ANALYTICAL CATEGORY

B-1 
This appendix identifies the approach to be taken to analyze for the list of dangerous waste constituents contained in WAC 173-303-9905. U.S. Testing Company, Inc. will conduct analyses for those constituents on the list for which methodology is currently available.

Table E.1 contains a numbered list of all of the WAC 173-303-9905 constituents, the specific method to be used for analysis, and references to one of several other tables (E.2 through E.10) which associates each constituents with an analytical category. Where available, SW-846 (USEPA, July 1982 "Test Methods for Evaluating Solid Waste) methods will be used. Where SW-846 does not provide sufficient information to analyze for a particular constituent, another standard method is listed. Two categories of compounds will not be analyzed directly:

1. constituents unstable in water

2. constituents for which no analytical method is available.

The following approach will be taken when analyzing for volatile and semivolatile constituents (Tables E.2 and E.3). A quantitative analysis will be performed by GC/MS on those compounds from these lists which are also on the Priority Pollutant 1ist (40 CFR Part 122). All other 9905 compounds will be searched for by NBS Library computer search of all peaks in the chromatogram of the sample which are greater than $20 \%$ of the nearest internal standard. Quantitation of the tentatively identified peak will be against the nearest internal standard, and the response factor will be assumed to be 1 . Rigorous quantitation of tentatively identified compounds will be performed upon request, and the analyses are subject to the availability of standards. 
Table E-1. Dangerous Waste Constituents List. (sheet 1 of 12)

\begin{tabular}{|c|c|c|c|c|}
\hline \multicolumn{3}{|c|}{ Constituent } & Methoda & Table \\
\hline$i$ & Acetonitrile & & $5 W-846,8270$ & E.3 \\
\hline 2 & Acetophenone & & SW-846, 8270 & $\varepsilon .3$ \\
\hline 3 & Warfarin & & $5 W-846,8270$ & E.3 \\
\hline 4 & 2-Acetylaminofluorene & & SW- 846,8270 & E.3 \\
\hline 5 & Acetyl chloride & & Unstable & $E .8$ \\
\hline 6 & 1-Acetyl-2-thiourea & & SW-846, 8330 & E. 10 \\
\hline 7 & Acrolein & & SW-846, 8240 & E.2 \\
\hline 8 & Acrylamide & & GCMS, Dir, Inj. & $E .4$ \\
\hline 9 & Acrylonitrile & & $S W-846,8240$ & E.2 \\
\hline 10 & Aflatoxins & & Exotic & E.9 \\
\hline 11 & Aldrin & & SW-846, 8080 & E.6 \\
\hline 12 & Allyl alcohol & & GOMS, Dir. Inj. & E.4 \\
\hline 13 & Aluminum phosphide & & Unstable & E.8 \\
\hline 14 & 4-Aminobiphenyl & . & SW- 846,8270 & E.3 \\
\hline 15 & Mitomycin C & & Exotic & E.9 \\
\hline 16 & 5-(Aminomethyl)-3-isoxazolol & & SW-846, 8270 & E. 3 \\
\hline 17 & Amitrole & & SW-846, 8270 & E.3 \\
\hline 18 & Aniline & & SW- 846,8270 & E. 3 \\
\hline 19 & Antimony and compounds & & SW-846, 6010 & E. 5 \\
\hline 20 & Aramite & - & $S W-846,8270$ & E.3 \\
\hline $2 !$ & Arsenic and compounds & & SW-846, 7060 & $\varepsilon .5$ \\
\hline 22 & Arsenic acid & & $5 W-846,7060$ & E.5 \\
\hline 23 & Arsenic pentoxide & & $5 \bar{W}-846,7060$ & E. 5 \\
\hline 24 & Arsenic trioxide & & $5 W-846,7060$ & E.5 \\
\hline 25 & Auramine & & SW-846, 8270 & E.3 \\
\hline 26 & Azaserine & & Exotic & E.9 \\
\hline 27 & Barium and compounds & & $5 W-846,5010$ & E.5 \\
\hline 28 & Barium cyanide & & SW-846, 6010 & E.5 \\
\hline 29 & Benz(c)acridine & & SW-846, 8270 & E.3 \\
\hline 30 & Benz(a)anthracene & & $S W-846,8270$ & E.3 \\
\hline 31 & Benzene & & SW-846, 8240 & E.2 \\
\hline 32 & Benzenearsonic acid & & $S W-846,7060$ & E.5 \\
\hline 33 & Benzene, dichloromethyl & & SW-846, 8270 & E.3 \\
\hline
\end{tabular}

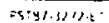


HNF-SD-TWR-TI-005, Rev. 0

Table E-1. Oangerous Waste Constituents List. (sheet 2 of 12)

\begin{tabular}{|c|c|c|c|c|}
\hline \multicolumn{3}{|c|}{ Constituent } & Methoda & Table \\
\hline 34 & Benzenethoil & & SW- 846,8270 & E.3 \\
\hline 35 & Benzidine & & SW-846, 8270 & $E .3$ \\
\hline 36 & Benzo(b)fluoranthene & & $5 W-846,8270$ & $E .3$ \\
\hline 37 & Benzo(j)fluoranthene & & SW-846, 8270 & $\varepsilon .3$ \\
\hline 38 & Benzo(a)pyrene & & SW-846, 8270 & E.3 \\
\hline 39 & p Benzoquinone & & SW-846. 8270 & E.3 \\
\hline 40 & Benzotrichloride & & Unstable & $E .8$ \\
\hline 41 & Benzyl chloride & & SW-846, 8720 & E. 3 \\
\hline 42 & Beryllium and compounds & & $5 W-846,6010$ & $E .5$ \\
\hline 43 & Bis(2-chloroethoxy)methane & & $5 W-846,8270$ & E.3 \\
\hline 44 & Bis(2-chloroethyl)ether & & SW-846, 8270 & E.3 \\
\hline 45 & Chlornaphazine & & SW-846, 8270 & E.3 \\
\hline 46 & Bis(2-chloroisopropy)ether & & SW-846, 8270 & E.3 \\
\hline 47 & Bis(chloromethyl)ether & & $S W-846,8240$ & E.2 \\
\hline 48 & Bis(2-ethylhexyl)phthalate & & SW-846, 8270 & E.3 \\
\hline 49 & Bromoacetone & & SW-846, 8240 & $\varepsilon .2$ \\
\hline 50 & Methyl bromide & & $S W \cdot 846,8240$ & $\varepsilon .2$ \\
\hline 51 & 4-Bromophenyl phenyl ether & & SW- 846,8270 & $\varepsilon .3$ \\
\hline 52 & Brucine & & Exotic & $\varepsilon .9$ \\
\hline 53 & 2-8utanone peroxide & - & Unstable & E.8 \\
\hline 54. & Butyl benzyl phthalate & & SW-846, 8270 & E.3 \\
\hline 55 & 2-sec-butyl-4,6-dinitrophenol & & $S W \cdot 846,8270$ & E. 3 \\
\hline 56 & Cadmium and compounds & & SW-846,6010 & E.5 \\
\hline 57 & Calcium chromate & & SW-846, 6010 & E.5 \\
\hline 58 & Calcium cyanide & & SW-846, 9010 & E.10 \\
\hline 59 & Carbon disolfice & & SW-846, 8240 & $\varepsilon .2$ \\
\hline $60^{\circ}$ & Carbon oxyfluoride & & Unstable & E.8 \\
\hline 61 & Chloral & & HOMS, Dir. Inj. & $\varepsilon .4$ \\
\hline 62 & Chlorambucil & & Exotic & E.9 \\
\hline 63 & Chlordane & & $5 W-846,8080$ & E. 6 \\
\hline 64 & Chlorinated benzenes & & SW- 846,8270 & E. 3 \\
\hline 65 & Chlorinated ethane & & $5 W-846,9020$ & E.7 \\
\hline 66 & Chlorinated fluorocarbons & & SW-846, 9020 & E.7 \\
\hline
\end{tabular}


HNF-SD-TWR-TI-005, Rev. 0

Table E-1. Dangerous Waste Constituents List. (sheet 3 of 12)

\begin{tabular}{|c|c|c|c|}
\hline \multicolumn{2}{|r|}{ Constituent } & Methoda & Table \\
\hline 67 & Chlorinated napthalene & $S W-846,9020$ & E.7 \\
\hline 68 & Chlorinated phenol & SW-846, 9020 & E.7 \\
\hline 69 & Chloroacetaldehyde & GCMS, Dir. Inj. & E.4 \\
\hline 70 & Chloroalkyl ethers & SW-846, 8270 & E.3 \\
\hline 71 & P.Choroaniline & SW-846, 8270 & E. 3 \\
\hline 72 & Chlorobenzene & SW-846, 8240 & E. 2 \\
\hline 73 & Chlorobenzilate & $A O A C-6.431$ & E.6 \\
\hline 74 & p-Chloro-m-cresot & SW- 846,8720 & E. 3 \\
\hline 75 & 1-Chloro-2,3-epoxypropane & SW- 846,8270 & E. 3 \\
\hline 76 & 2-Chloroethyl vinyl ether & $S W-846,8240$ & E.2 \\
\hline 77 & Chloroform & $S W-846,8240$ & E. 2 \\
\hline 78 & Methyl chloride & $S W-846,8240$ & E. 2 \\
\hline 79 & Chloromethyl methyl ether & $S W-846,8240$ & E. 2 \\
\hline 80 & 2-Chloronaphthalene & SW- 846,8270 & E.3 \\
\hline 81 & 1-Chlorophenol & $S W-846,8270$ & E.3 \\
\hline 82 & 1 -(o-Chlorophenyl) thiourea & SW- 846,8330 & $\varepsilon .10$ \\
\hline 83 & 3-Chloropropionitrile & GOMS, Dir. Inj. & E. 4 \\
\hline 84 & Chromium and compounds & $5 W-846,6010$ & E.5 \\
\hline 85 & Chrysene & SW- 846,8270 & E.3 \\
\hline 86 & Citrus red no. 2 & $A O A C-34.0158$ & E.10 \\
\hline 87 & Coal tars & SM-505 & E.7 \\
\hline 88 & Copper cyanide & SW-846, 6010 & E.5 \\
\hline 89 & Creosote & $5 M-505$ & E.7 \\
\hline 90 & Cresols & SW-846, 8270 & E.3 \\
\hline 91 & Crotonaldehyde & SW-846, 8240 & E. 2 \\
\hline 92 & Cyanides & $5 W-846,9010$ & E.10 \\
\hline 93 & Cyanogen & GC/MS, Dir. Inj. & E.4 \\
\hline 94 & Cyanogen bromide & $A O A C-340.15 B$ & E.10 \\
\hline 95 & Cyanogen chloride & $A O A C-34.015 B$ & E.10 \\
\hline 96 & Cycasin & Exotic & E.9 \\
\hline 97 & 2-Cyclohexyl-4.6-dinitrophenol & SW-846, 8270 & E.3 \\
\hline 98 & cyclophosphamide & Exotic & E.9 \\
\hline 99 & Daunomycin & Exotis & E. 9 \\
\hline
\end{tabular}


Table E-1. Dangerous Waste Constituents List. (sheet 4 of 12)

\begin{tabular}{|c|c|c|c|c|}
\hline \multicolumn{3}{|c|}{ Constituent } & Methoda & Table \\
\hline 100 & ODD & & $5 W-846,8080$ & $E .6$ \\
\hline 101 & DDE & & $5 W-846,8080$ & E.6 \\
\hline 102 & DDT & & $S W-846.8080$ & E.6 \\
\hline 103 & Diallate & & Exotic & $E .9$ \\
\hline 104 & Dibenz(a,h)acridine & & SW- 846,8270 & E.3 \\
\hline 105 & Dibenz(a,j)acridine & & $S W \cdot 846,8270$ & E.3 \\
\hline 106 & Dibenz(a,h)anthracene & & $S W \cdot 846,8270$ & E.3 \\
\hline 107 & 7H-Dibenzo(c,g)carbazole & & SW-846, 8720 & E.3 \\
\hline 108 & Dibenzo(a,e)pyrene & & SW- 846,8720 & E. 3 \\
\hline 109 & Debenzo $(a, h)$ pyrene & & SW-846, 8270 & E. 3 \\
\hline 110 & Debenzo(a,i)pyrene & & SW-846, 8270 & E.3 \\
\hline 111 & 1,2-Dibromo-3-chioropropane & & SW- 846,8240 & E.2 \\
\hline 112 & 1,2-Dibromoethane & & SW- 846,8240 & E.2 \\
\hline 113 & Dibromomethane & $=$ & SW- 846,8240 & $E .2$ \\
\hline 114 & Di-n-butyl phthalate & & SW-846, 8270 & E. 3 \\
\hline 115 & Benzene, 1,2-dichloro & & SW- 846,8270 & E.3 \\
\hline 116 & Benzene, 1,3-dichloro & & SW- 846,8270 & E. 3 \\
\hline 117 & Benzene, 1,4-dichloro & & SW- 846,8270 & E.3 \\
\hline 118 & Dichlorobenzene & & $S W-846,9020$ & E.7 \\
\hline 119 & 3.3'-Dichlorobenzidine & . & SW- 846,8270 & E. 3 \\
\hline 120 & 1,4-Dichloro-2-butene & & $S W-846,8240$ & E. 2 \\
\hline 121 & Dichlorodifluoromethane & & SW- 846,8240 & $\varepsilon .2$ \\
\hline 122 & 1,1-Dichloroethane & & $S \dot{W}-846,8240$ & $E .2$ \\
\hline 123 & 1,2-dichloroethane & & $5 W-846,8240$ & E. 2 \\
\hline 124 & tran-1,2-Dichloroethene & & $S W-846,8240$ & E.2 \\
\hline 125 & Dichloroethylene & & SW-846, 9020 & E.7 \\
\hline 126 & 1,1-Dichioroethylene & & SW-846, 8240 & E.2 \\
\hline 127 & Methylene chloride & & SW- 846,8240 & E.2 \\
\hline 128 & 2,4-Dichlorophenol & & SW- 846,8270 & E. 3 \\
\hline 129 & 2,6-Dichlorophenol & & SW-846, 8270 & E. 3 \\
\hline 130 & $2,4 \cdot 0$ & & $5 W-846,8150$ & E.6 \\
\hline 131 & Dichlorophenylarsine & & $5 W-846,7060$ & E.5 \\
\hline 132 & Dichloropropane & & SW-846, 9020 & E.7 \\
\hline
\end{tabular}


Table E-1. Dangerous Waste Constituents List. (sheet 5 of 12)

\begin{tabular}{|c|c|c|c|}
\hline \multicolumn{2}{|r|}{ Constituent } & Methodd & Table \\
\hline 133 & 1,2-Dichloropropane & $5 W-846,8240$ & E.2 \\
\hline 134 & Dichloropropanol & GOMS, Dir. Inj. & $E .4$ \\
\hline 135 & Dichloropropene & SW-846, 9020 & E.7 \\
\hline 136 & 1,3-Dishloropropene & SW-846, 8240 & E.2 \\
\hline 137 & Dieldrin & SW-846, 8080 & E. 6 \\
\hline 138 & 1,2:3,4-Diepoxybutane & Unstable & $E .8$ \\
\hline 139 & Diethylarsine & SW-846, 7060 & E.5 \\
\hline 140 & N,N-Diethylhydrazine & SW-846, 8240 & E.2 \\
\hline 141 & Carbophenothion & AOAC-29.039 & E.6 \\
\hline 142 & $\begin{array}{l}\text { O,O-Diethylphosphoric acid. } \\
\text { O-p-nitrophenyl ester }\end{array}$ & Exotic & E.9 \\
\hline 143 & Diethyl phthalate & SW-846, 8270 & E.3 \\
\hline 144 & Thionazin & Exotic & E.9 \\
\hline 145 & Diethylstilbesterol & $5 W-846,8330$ & $E .10$ \\
\hline 146 & Dihydrosafrole & SW-846, 8270 & E.3 \\
\hline 147 & $\begin{array}{l}\text { 3,4-Dihydroxy-alpha-(methylamino) } \\
\text { methyl benzyl alchol }\end{array}$ & Exotic & E.9 \\
\hline 148 & Diisopropylfluorophosphate & Unstable & E.8 \\
\hline 149 & Dimethoate & $5 W-846,8140$ & E.9 \\
\hline 150 & 3,3'-Dimethoxybenzidine & $5 W-846,8270$ & E.3 \\
\hline 151 & p-Dimethylaminoazobenzene & SW-846, 8270 & $E .3$ \\
\hline 152 & 7,12-Dimethylbenz(a)anthracene & $5 W-846,8270$ & E.3 \\
\hline 153 & 3,3'Dimethylbenzidine & SW- 846,8270 & E.3 \\
\hline 154 & Dimethylcarbamoyl chloride & Unstable & E.8 \\
\hline 155 & 1,1-Dimethylhydrazine & $5 W-846,8240$ & E.2 \\
\hline 156 & 1,2-Dimethylhydrazine & SW- 846,8240 & E.2 \\
\hline 157 & Thiofanox & SW- 846,8270 & $\varepsilon .3$ \\
\hline 158 & alpha, alpha-Dimethylphenethylamine & $5 W \cdot 846,8270$ & E.3 \\
\hline 159 & 2,4-Dimethylphenol & $5 W-846,8270$ & E.3 \\
\hline 160 & Dimethyl phthalate & SW-846, 8270 & E.3 \\
\hline 161 & Dimethyl sulfate & Unstable & E.8 \\
\hline 162 & Dinitrobenzene & SW-846, 8270 & E.3 \\
\hline 163 & 4,6-Dinitro-o-cresol and salts & $S W \cdot 846.8270$ & E.3 \\
\hline
\end{tabular}


Table E-1. Dangerous Waste Constituents List. (sheet 6 of 12)

\begin{tabular}{|c|c|c|c|}
\hline & Constituent & Methodd & Table \\
\hline 164 & 2,4-Dinitrophenol & SW-846, 8270 & E.3 \\
\hline 165 & 2,4-Dinitrotoluene & SW-846, 8270 & E.3 \\
\hline 166 & 2,6-Dinitrotolvene & SW-846, 8270 & E.3 \\
\hline 167 & Di-n-octyl phthalate & SW. 846.8270 & E.3 \\
\hline 168 & 1.4-Dioxane & SW-846, 8240 & E.2 \\
\hline 169 & Diphenylamine & SW-846, 8270 & E.3 \\
\hline 170 & 1,2-Diphenylhydrazine & SW-846, 8270 & E.3 \\
\hline 171 & Di-n-propylnitrosamine & SW- 846,8270 & E.3 \\
\hline 172 & Disulfoton & SW-846, 8140 & E.6 \\
\hline 173 & 2,4-Dithiobiuret & Exotic & E.9 \\
\hline 174 & Endosulfan & SW-846. 8080 & E.6 \\
\hline 175 & Endosulfan & $S W \cdot 846,8080$ & E.6 \\
\hline 176 & Ethyl carbamate & GC/MS, Dir. Inj. & E.4 \\
\hline 177 & Ethyl cyanide & GCMS, Dir. Inj. & E.4 \\
\hline 178 & Ethylenebisdithiocarbamic acid & Exotic & $E .9$ \\
\hline 179 & Ethyleneimine & SW- 846,8270 & E.3 \\
\hline 180 & Ethylene oxide & GCIMS, Dir. Inj. & E.4 \\
\hline 181 & Ethylenethiorea & SW- 846,8330 & E. 10 \\
\hline 182 & Ethylmethacrylate & GCMS, Dir. Inj. & E.4 \\
\hline 183 & Ethyl methanesulfonate & $S W-846,8270$ & $E .3$ \\
\hline 184 & Fluoranthene & $5 W \cdot 846,8270$ & E.3 \\
\hline 185 & Fluorine & Unstable. & E.8 \\
\hline 186 & 2-Fluoroacetamide & Exotic - & $E .9$ \\
\hline 187 & Fluoroacetic acid & GOMS, Dir. Inj. & $E .4$ \\
\hline 188 & Formaldehyde & Ion Chrom. (in-house) & E. 10 \\
\hline 189 & Formic acid & Ion Chrom. (in-house) & E. 10 \\
\hline 190 & Glycidylaldehyde & GCMS, Dir. Inj. & E.4 \\
\hline 191 & Halomethane & HCMMS, Dir. 9020 & E.7 \\
\hline 192 & Heptachlor & SW- 846,8080 & E.6 \\
\hline 193 & Heptachlor epoxide & SW- 846,8080 & E.6 \\
\hline 194 & Hexachlorobenzene & SW-846, 8270 & $E .3$ \\
\hline 195 & Hexachlorobutadiene & SW-846, 8270 & E.3 \\
\hline 196 & Lindane and isomers & SW-846, 8080 & E. 6 \\
\hline
\end{tabular}


Table E-1. Dangerous Waste Constituents List. (sheet 7 of 12)

\begin{tabular}{|c|c|c|c|}
\hline & Constituent & Methoda & Table \\
\hline 197 & Hexachlorocylopentadiene & SW-846, 8270 & E.3 \\
\hline 198 & Hexachloroethane & SW-846, 8270 & E.3 \\
\hline 199 & $\begin{array}{l}\text { Hexachlorohexahydro-endo, endo- } \\
\text { dimethanonaphthalene }\end{array}$ & Exotic & $\varepsilon .9$ \\
\hline 200 & Hexachlorophene & $5 W-846,8270$ & E.3 \\
\hline 201 & Hexachloropropene & SW-846, 8270 & E.3 \\
\hline 202 & Hexaethyl tetraphosphate & Exotic & E.9 \\
\hline 203 & Hydrazine & Sw-846, 8270 & E.3 \\
\hline 204 & Hydrocyanic acid & $5 W-846,9010$ & E. 10 \\
\hline 205 & Hydrofluoric acid & Unstable & E.8 \\
\hline 206 & Hydrogen sulfide & $S W-846,8240$ & E.2 \\
\hline 207 & Hydroxydimethylarsine oxide & SW-846, 7060 & E.5 \\
\hline 208 & Indeno(1,2,3-cd)pyrene & SW- 846,8270 & $\varepsilon .3$ \\
\hline 209 & lodomethane & SW- 846,8240 & E.2 \\
\hline 210 & Iron Dextran & Exotic & E.9 \\
\hline 211 & Methyl isocyanate & Unstable & E. 8 \\
\hline 212 & isobutyl alcohol & GOMS, Dir. Inj. & $E .4$ \\
\hline 213 & Isosafrole & $5 W-846,8270$ & E. 3 \\
\hline 214 & Kepone & $5 W-846,8080$ & E. 5 \\
\hline 215 & Lasiocarpine & Exotic & E.9 \\
\hline 216 & Lead and compounds & $5 W-846,6010$ & $E .5$ \\
\hline 217 & Lead acetate & SW-846, 6010 & $E .5$ \\
\hline 218 & Lead phosphate & $S W-846,6010$ & E.5 \\
\hline 219 & Lead subacetate & $5 W-845,6010$ & E.5 \\
\hline 220 & Maleic anhydride & Unstable & E. 8 \\
\hline 221 & Maleic hydrazide & AOAC-29.129 & E. 10 \\
\hline 222 & Malonoitrile & SW-846, 8270 & $\varepsilon .3$ \\
\hline 223 & Melphaian & SW-846, 8270 & $E .3$ \\
\hline 224 & Mercury Fulminate & SW- 846,7470 & E.5 \\
\hline 225 & Mercury and compounds & $5 W-846,7470$ & $E .5$ \\
\hline 226 & Methacrylonitrile & SW-846, 8240 & $E .2$ \\
\hline 227 & Methanethiol & SW-846, 8240 & E.2 \\
\hline 228 & Methapyrilene & SW-846, 8270 & E. 3 \\
\hline
\end{tabular}


Table E-1. Dangerous Waste Constituents List. (sheet 8 of 12)

\begin{tabular}{|c|c|c|c|}
\hline \multicolumn{2}{|r|}{ Constituent } & Methoda & Table \\
\hline 229 & Metholonyl & SW-846, 8270 & E.3 \\
\hline 230 & Methoxychlor & $S W-846,8080$ & E. 6 \\
\hline 231 & 2-Methylaziridine & SW-846, 8270 & E. 3 \\
\hline 232 & 3-Methylcholanthrene & $S W \cdot 846,8270$ & E.3 \\
\hline 233 & Methyl chlorocarbonate & Unstable & $E .8$ \\
\hline 234 & $4,4^{\prime}$ - Methylenebis & SW-846, 8270 & E.3 \\
\hline 235 & Methyl ethyi ketone & $S W \cdot 846,8240$ & E. 2 \\
\hline 236 & Methyl hydrazine & GCMS, Dir. Inj. & E.4 \\
\hline 237 & 2-Methyllactonitrile & $5 W-846,8270$ & E.3 \\
\hline 238 & Methyl methacrylate & $5 W-846,8270$ & $E .3$ \\
\hline 239 & Methyl methanesulfonate & SW- 846,8270 & E. 3 \\
\hline 240 & $\begin{array}{l}\text { 2-Methyl-2-(methylthio) } \\
\text { propionaldehyde-o- } \\
\text { (methyl carbonyl) oxime }\end{array}$ & $5 W-846,8270$ & $E .3$ \\
\hline 241 & $\begin{array}{l}\text { N-Methyl-N`-nitro- } \\
N \text {-nitrosoguanidine }\end{array}$ & Exotic & E.9 \\
\hline 242 & Methyl parathion & $5 W-846,8140$ & E.6 \\
\hline 243 & Methylthiouracil & $5 W-846,8270$ & E.3 \\
\hline 244 & Mustard gas & Exotic & $E .9$ \\
\hline 245 & Naphthalene & $S W-846,8270$ & E.3 \\
\hline 246 & 1,4-Haphthoquinone & SW-846, 8270 & E.3 \\
\hline 247 & 1-Naphthylamine & SW-846, 8270 & E.3 \\
\hline 248 & 2-Naphthylamine & SW-846, 8270 & $E .3$ \\
\hline 249 & 1-Naphthyl-2-thiourea & $5 W-846,8330$ & E. 10 \\
\hline 250 & Nickel and compounds & $5 W-846,6010$ & E. 5 \\
\hline 251 & Nickel carbonyl & $S W-846,6010$ & $\varepsilon .5$ \\
\hline 252 & Nickel cyanide & SW-846, 6010 & E.5 \\
\hline 253 & Nicotine and salts & $A O A C-43.444$ & E. 10 \\
\hline 254 & Nitric oxide & Exotic & E.9 \\
\hline 255 & p-Nitroaniline & SW-846, 8270 & E. 3 \\
\hline 256 & Nitrobenzine & SW-846, 8270 & E.3 \\
\hline 257 & Nitrogen dioxide & Unstable & E.8 \\
\hline 258 & $\begin{array}{l}\text { Nitrogen mustard and hydrochloride } \\
\text { salt }\end{array}$ & Exotic & E.9 \\
\hline
\end{tabular}

Dq $9.3272 \div 1$ 
Table E-1. Dangerous Waste Constituents List. (sheet 9 of 12)

\begin{tabular}{|c|c|c|c|}
\hline \multicolumn{2}{|r|}{ Constituent } & Methoda & Table \\
\hline 259 & $\begin{array}{l}\text { Nitrogen mustard } \mathrm{N} \text {-Oxide and } \\
\text { hydrochloride salt }\end{array}$ & Exotic & E.9 \\
\hline 260 & Nitroglycerine & Exotic & E.9 \\
\hline 261 & 4-Nitrophenol & SW-846, 8270 & E.3 \\
\hline 262 & 4-Nitroquinoline-1-oxide & Exotic & E.9 \\
\hline 263 & Nitrosamine & $5 M-417$ & E.7 \\
\hline 264 & N-Nitrosodi-n-butylamine & SW- 846,8270 & E.3 \\
\hline 265 & N-Nitrosodiethanolamine & SW-846, 8270 & E.3 \\
\hline 266 & N-Nitrosodiethylamine & $5 W-846,8720$ & E.3 \\
\hline 267 & N-Nitrosodimethylamine & SW-846, 8270 & E. 3 \\
\hline 268 & N-Nitroso-N-ethylurea & SW-846, 8330 & E.3 \\
\hline 269 & N-Nitrosomethylethylamine & $S W \cdot 846,8270$ & $E .3$ \\
\hline 270 & N-Nitroso-N-methylurea & SW-846, 8330 & E.10 \\
\hline 271 & N-Nitroso-N-methylurethane & SW-846, 8270 & E.3 \\
\hline 272 & N-Nitrosomethylvinylamine & SW-846, 8270 & E.3 \\
\hline 273 & N-Nitrosomorpholine & SW-846, 8270 & E. 3 \\
\hline 274 & $\mathrm{~N}$-Nitrosonornicotine & $5 W-846,8270$ & E.3 \\
\hline 275 & N-Nitrosopiperidine & SW-846, 8270 & E.3 \\
\hline 276 & Nitrosopyrrolidine & SW- 846,8270 & E.3 \\
\hline 277 & N-Nitrososacrosine & Exotic & E.9 \\
\hline 278 & 5-Nitro-o-toluidine & $5 W-846,8270$ & E.3 \\
\hline 279 & Octamethylpyprophosphoramide & Exotic & E.9 \\
\hline 280 & Osmium tetroxide & $5 W-846,6010$ & E.5 \\
\hline 281 & Endothol & Exotic & E.9 \\
\hline 282 & Paraldehyde & Exotic & E.9 \\
\hline 283 & Parathion & SW-846, 8140 & E. 5 \\
\hline 284 & Pentachiorobenzene & SW- 846,8270 & E.3 \\
\hline $28 \dot{5}$ & Pentachloroethane & SW-846, 8240 & E. 2 \\
\hline 286 & Pentachloronitrobenzene & SW-846, 8270 & E. 3 \\
\hline 287 & Pentachlorophenol & SW- 846,8270 & E. 3 \\
\hline 288 & Phenacetin & SW-846، 8270 & E. 3 \\
\hline 289 & Phenol & $5 W-846,8270$ & E. 3 \\
\hline 290 & Phenylenediamine & SW- 846,8270 & E.3 \\
\hline
\end{tabular}


Table E-1. Dangerous Waste Constituents List. (sheet 10 of 12)

\begin{tabular}{|c|c|c|c|}
\hline \multicolumn{2}{|r|}{ Constituent } & Methodd & Table \\
\hline 291 & Phenylmercury acetate & SW-846, 7470 & $E .5$ \\
\hline 292 & N-Phenylthiuourea & SW-846, 8330 & E. 10 \\
\hline 293 & Phosgene & Unstable & E.8 \\
\hline 294 & Phosphine & Exotic & E.9 \\
\hline 295 & Phorate & Unstable & E. 8 \\
\hline 296 & Famphur & Unstable & $\varepsilon .8$ \\
\hline 297 & Phthalic acid esters & SW-846, 8270 & E.3 \\
\hline 298 & Phthalic anhydride & Unstable & E.8 \\
\hline 299 & 2-Picoline & $5 W-846,8270$ & E.3 \\
\hline 300 & Polychlorinated biphenyl & $5 W-846,8080$ & E.6 \\
\hline 301 & Potassium cyanide & SW-846, 9010 & E. 10 \\
\hline 302 & Potassium silver cyanide & $5 W \cdot 846,6010$ & E.5 \\
\hline 303 & Pronamide & $S W-846,8270$ & E.3 \\
\hline 304 & 1,3-Propanesultone & Exotic & E.9 \\
\hline 305 & n-Propylamine & GCMS, Dir. Inj. & E.4 \\
\hline 306 & Propylthiouracil & Exotic & $\varepsilon .9$ \\
\hline 307 & 2-Propyn-1-ol & GCIMS, Dir. Inj. & E.4 \\
\hline 308 & Pyridine & SW-846, 8240 & E. 2 \\
\hline 309 & Reserpine & SW-846, 8270 & E.3 \\
\hline 310 & Resorcinol & $5 W-846,8270$ & E. 3 \\
\hline 311 & Saccharin and salts & Exotic & E.9 \\
\hline 312 & Sasfrol & $S W-846,8270$ & E. 3 \\
\hline 313 & Selenious acid & SW- 846,7740 & $E .5$ \\
\hline 314 & Selenium and compounds & SW-846.7740 & E.5 \\
\hline 315 & Selenium sulfide & $5 W-846,7740$ & $E .5$ \\
\hline 316 & Selenourea & SW-846, 7740 & $\varepsilon .5$ \\
\hline 317. & Silver and compounds & SW-846, 6010 & $E .5$ \\
\hline 318 & Silver cyanide & SW-846, 6010 & E.5 \\
\hline 319 & Sodium cyanide & $5 W-846,9010$ & E. 10 \\
\hline 320 & Streptozotocin & Exotic & E.9 \\
\hline 321 & Strontium sulfide & SW-846. 6010 & E. 5 \\
\hline 322 & Strychnine and salts & AOAC -38.068 & E. 10 \\
\hline 323 & 1,2,4,5-Tetrachlorobenaene & SW-846, 8270 & E.3 \\
\hline
\end{tabular}


HNF-SD-TWR-TI-005, Rev. 0

Table E-1. Dangerous Waste Constituents List. (sheet 11 of 12)

\begin{tabular}{|c|c|c|c|}
\hline \multicolumn{2}{|r|}{ Constituent } & Methoda & Table \\
\hline 324 & TCOD & $S W-846,8270$ & $E .3$ \\
\hline 325 & Tetrachloroethane & SW-846.8240 & E.2 \\
\hline 325 & 1,1,1,2-Tetrachlorethane & SW-846, 8240 & E. 2 \\
\hline 327 & 1,1,2,2-Tetrachlorethane & SW- 846,8240 & E.2 \\
\hline 328 & Tetrachlorethylene & $S W-846,8240$ & E.2 \\
\hline 329 & Tetrachloromethane & $S W \cdot 846,8240$ & E.2 2 \\
\hline 330 & 2,3,4,6-Tetrachlorophenol & $5 W \cdot 846,8270$ & E.3 \\
\hline 331 & Tetraethyldithiopyrophosphate & Unstable & $\varepsilon .8$ \\
\hline 332 & Tetraethyl lead & $5 W-846,67010$ & E.5 \\
\hline 333 & Tetraethylpyrophosphate & Exotic & E.9 \\
\hline 334 & Tetranitromethane & Exotis & $E .9$ \\
\hline 335 & Thallium and compounds & $5 W-846,7840$ & E.5 \\
\hline 336 & Thallic oxide & $5 W-846,7840$ & E.5 \\
\hline 337 & Thallium (1) acetate & SW- 846,7840 & E. 5 \\
\hline 338 & Thallium (1) carbonate & $S W-846,7840$ & E. 5 \\
\hline 339 & Thallium (1) chloride & SW. 846,7840 & E.5 \\
\hline 340 & Thaliium (1) nitrate & SW-846, 7840 & $E 5$ \\
\hline 341 & Thallium selenite & SW-846, 7840 & $E .5$ \\
\hline 342 & Thallium (1) sulfate & $5 W-846,7840$ & E. 5 \\
\hline 343 & Thioacetamide & Exotis & $E .9$ \\
\hline 344 & Thiosemicarbazide & Exotic & E.9 \\
\hline 345 & Thiourea & SW-846, 8330 & E. 10 \\
\hline 346 & Thiuram & $5 W-846,8270$ & E. 3 \\
\hline 347 & Tolvene & SW-846, 8240 & E. 2 \\
\hline 348 & Toluenediamine & $5 W-846,8270$ & E. 3 \\
\hline 349 & o-Toluidine hydrochloride & SW-846, 8270 & E. 3 \\
\hline 350 & Tolulene diisocyanate & Unstable & E.8 \\
\hline 351 & Toxaphene & SW-846, 8080 & E.6 \\
\hline 352 & Bromoform & $5 W-846,8240$ & E. 2 \\
\hline 353 & 1,2,4-Trichlorobenzene & SW-846, 8270 & E.3 \\
\hline 354 & 1,1,1-Trichloroethane & $5 W-846,8240$ & E. 2 \\
\hline 355 & 1,1,2-Trichloroethane & SW- 846,8240 & E. 2 \\
\hline 356 & Trichloroethene & $5 W-846,8240$ & E. 2 \\
\hline
\end{tabular}

$=\{19 / .3 / 2, E$, 
HNF-SD-TWR-TI-005, Rev. 0

Table E-1. Dangerous Waste Constituents List. (sheet 12 of 12)

\begin{tabular}{|c|c|c|c|}
\hline & Constituent & Methodd & Table \\
\hline 357 & Trichloromethanethiol & SW-846, 8240 & E.2 \\
\hline 358 & Trichloromonofluoromethane & SW. 846,8240 & E. 2 \\
\hline 359 & 2,4,5-Trichlorophenol & SW-846, 8270 & E.3 \\
\hline 360 & 2,4,6-Trichlorophenol & SW-846, 8270 & E.3 \\
\hline 361 & $2,4,5-T$ & $5 W-846,8150$ & E.6 \\
\hline 362 & $2,4,5-T P($ Silvex) & SW-846, 8150 & E.6 \\
\hline 363 & Trichloropropane & $S W-846,8240$ & $\varepsilon .2$ \\
\hline 364 & 1,2,3-Trichloropropane & SW-846, 8240 & E.2 \\
\hline 365 & $0,0,0$-Triethyl phosphorothioate & SW-846, 8270 & E.3 \\
\hline 366 & sym-Trinitrobenzene & $5 W-846,8270$ & E.3 \\
\hline 367 & Tris(1-aziridinyl) phosphine sulfide & Unstable & E. 8 \\
\hline 368 & Tris(2,3-dibromopropyl) phosphate & SW- 846,8270 & E.3 \\
\hline 369 & Trypan blue & Exotic & E.9 \\
\hline 370 & Uracil mustard & Exotic & E.9 \\
\hline 371 & Vanadic acid, ammonium salt & SW-846, 6010 & E.5 \\
\hline 372 & Vanadium pentoxide & SW- 846,6010 & $\varepsilon .5$ \\
\hline 373 & Vinyl chloride & $S W \cdot 846,8240$ & E. 2 \\
\hline 374 & Zinc cyanide & $5 W-846,6010$ & E.5 \\
\hline 375 & Zinc phosphide & Unstable & E.8 \\
\hline
\end{tabular}

asW-846: Environmental Protection Agency, 1982. Test Methods for

Evatuating Solid Waste - Chemical/Physical Methods, SW-846. SM: American Public Health Association, 1985. Standard Methods for the Examination of Water and Waste Water, APHA, Washington, D.C. AOAC: Journal of the Association of Official Analytical Chemists. 
Table E-2. Volatile Organics.

(sheet 1 of 2)

\begin{tabular}{|c|c|}
\hline 7 & Acrolein \\
\hline 9 & Acrylonitrile \\
\hline 31 & Benzene \\
\hline 47 & Bis(chloromethyl)ether \\
\hline 49 & Bromoacetone \\
\hline 50 & Methyl bromide \\
\hline 59 & Carbon disulfide \\
\hline 72 & Chlorobenzene \\
\hline 76 & 2-Chloroethyl vinyl ether \\
\hline 77 & Chloroform \\
\hline 78 & Methyl chloride \\
\hline 79 & Chloromethyl methyl ether \\
\hline 91 & Crotonaldehyde \\
\hline $11 i$ & 1,2-Dibromo-3-chloropropane \\
\hline 112 & 1,2-Dibromoethane \\
\hline 113 & Dibromomethane \\
\hline 120 & 1.4-Dichloro-2-butene \\
\hline 121 & Dichlorodifluoromethane \\
\hline 122 & 1,1-Dichloroethane \\
\hline 123 & 1,2-Dichloroethane \\
\hline 124 & trans-1,2-Dishloroethane \\
\hline 126 & 1,1-Dichloroethylene \\
\hline 127 & Methylene chloride \\
\hline 133 & 1,2-Dichloropropane \\
\hline 136 & 1.3.Dichloropropane \\
\hline 140 & N,N-Diethylhydrazine \\
\hline 155 & 1,1-Dimethylhydrazine \\
\hline 156 & 1,2-Dimethylhydrazine \\
\hline 168 & Dioxane \\
\hline 206 & Hydrogen sulfide \\
\hline
\end{tabular}


HNF-SD-TWR-TI-005, Rev. 0

Table E-2. Volatile Organics.

(sheet 2 of 2 )

\begin{tabular}{ll}
209 & lodomethane \\
226 & Methacrylonitrile \\
227 & Methanethiol \\
235 & Methyl ethyl ketone \\
285 & Pentachloroethane \\
308 & Pyridine \\
325 & Tetrachloroethane \\
326 & $1,1,1,2-$ Tetrachlorethane \\
327 & $1,1,2,2-$ Tetrachlorethane \\
328 & Tetrachlorethylene \\
329 & Tetrachloromethane \\
347 & Toluene \\
352 & Bromoform \\
354 & $1,1,1-$ Trichloroethane \\
355 & $1,1,2-T r i c h l o r o e t h a n e$ \\
356 & Trichloroethane \\
357 & Trichloromethanethiol \\
358 & Trichloromonofluoromethane \\
363 & Trichloropropane \\
364 & $1,2,3-$ Trichloropropane \\
373 & Vinyl chloride \\
\hline
\end{tabular}

ins $31.1 /(1) \cdot e \cdot 1$ 
HNF-SD-TWR-TI-005, Rev. 0

Table E-3. Semi-Volatile Organics. (sheet 1 of 5)

\begin{tabular}{|cl|}
\hline 1 & Acetonitrile \\
2 & Acetophenone \\
4 & 2-Acetylaminofluorene \\
14 & 4-Aminobyphenyl \\
16 & 5-(Aminomethyl)-3-ioxazolol \\
17 & Amitrole \\
18 & Aniline \\
20 & Aramite \\
25 & Auramine \\
29 & Benz[c]acridine \\
30 & Benzlalanthracene \\
33 & Benzene, dichloromethyl- \\
34 & Benzenethoil \\
35 & Benzidine \\
36 & Benzolb]fluoranthene \\
37 & Benzolj]fluoranthene \\
38 & Benzolalpyene \\
39 & p Benzoquinone \\
41 & Benzyl chloride \\
43 & Bis(2-chloroethoxy)methane \\
44 & Bis(2-chloroethyl)ether \\
45 & Chlornaphazine \\
46 & Bis(2-chloroisopropyl)ether \\
48 & Bis(2-ethylhexyl) phthalate \\
51 & 4 -Bromophenyl phenyl ether \\
54 & Butylbenzyl phthalate \\
55 & 2-sec-Butyl-4,6-dinitrophenol \\
64 & Chlorinated benzenes \\
70 & Chloroalkyl ethers \\
\hline 1 & p-chloraniline \\
\end{tabular}

p.: $91.3212:-1$ 
Table E-3. Semi-Volatile Organics. (sheet 2 of 5)

\begin{tabular}{|c|c|}
\hline 75 & 1-Chloro-2,3-epoxypropane \\
\hline 80 & 2.Chloronaphythalene \\
\hline 81 & 2-Chlorophenol \\
\hline 85 & Chrysene \\
\hline 90 & Cresols \\
\hline 97 & 2-Cyclohexyl-4,6-dinitrophenol \\
\hline 104 & Dibenz[a,h]acridine \\
\hline 105 & Dibenz[a.j]acridine \\
\hline 106 & Dibenzla,h]anthracene \\
\hline 107 & 7H-Dibenzolc,glcarbazole \\
\hline 108 & Dibenzola,e]pyrene \\
\hline 109 & Dibenzo[a,h]pyrene \\
\hline 110 & Dibenzo[a.i]pyrene \\
\hline 114 & Di-n-butyl phthalate \\
\hline 115 & 1,2-Dichlorobenzene \\
\hline 116 & 1,3-Dichlorobenzene \\
\hline 117 & 1,4-Dichlorobenzene \\
\hline 119 & 3,3'-Dichlorobenzidine \\
\hline 128 & 2,4-Dichlorophenol \\
\hline 129 & 2,6-Dichiorophenol \\
\hline 143 & Diethyl phthalate \\
\hline 146 & Dihydrosafrole \\
\hline 150 & 3,3'-Dimethoxybenzidine \\
\hline 151 & p-Dimethylaminoazobenzene \\
\hline 152 & 7,12-Dimethlybenz[a]anthracene \\
\hline 153 & 3.3'-Dimethylbenzidine \\
\hline 157 & Thiofanox \\
\hline 158 & alpha, alpha-Dimethiphenethylamine \\
\hline 159 & 2,4-Dimethylphenol \\
\hline 160 & Dimethyl phthalate \\
\hline 162 & Dinitrobenzene \\
\hline 163 & 4,6-Dinitro-0-cresol and salts \\
\hline
\end{tabular}

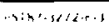


Table E-3. Semi-Volatile Organics. (sheet 3 of 5)

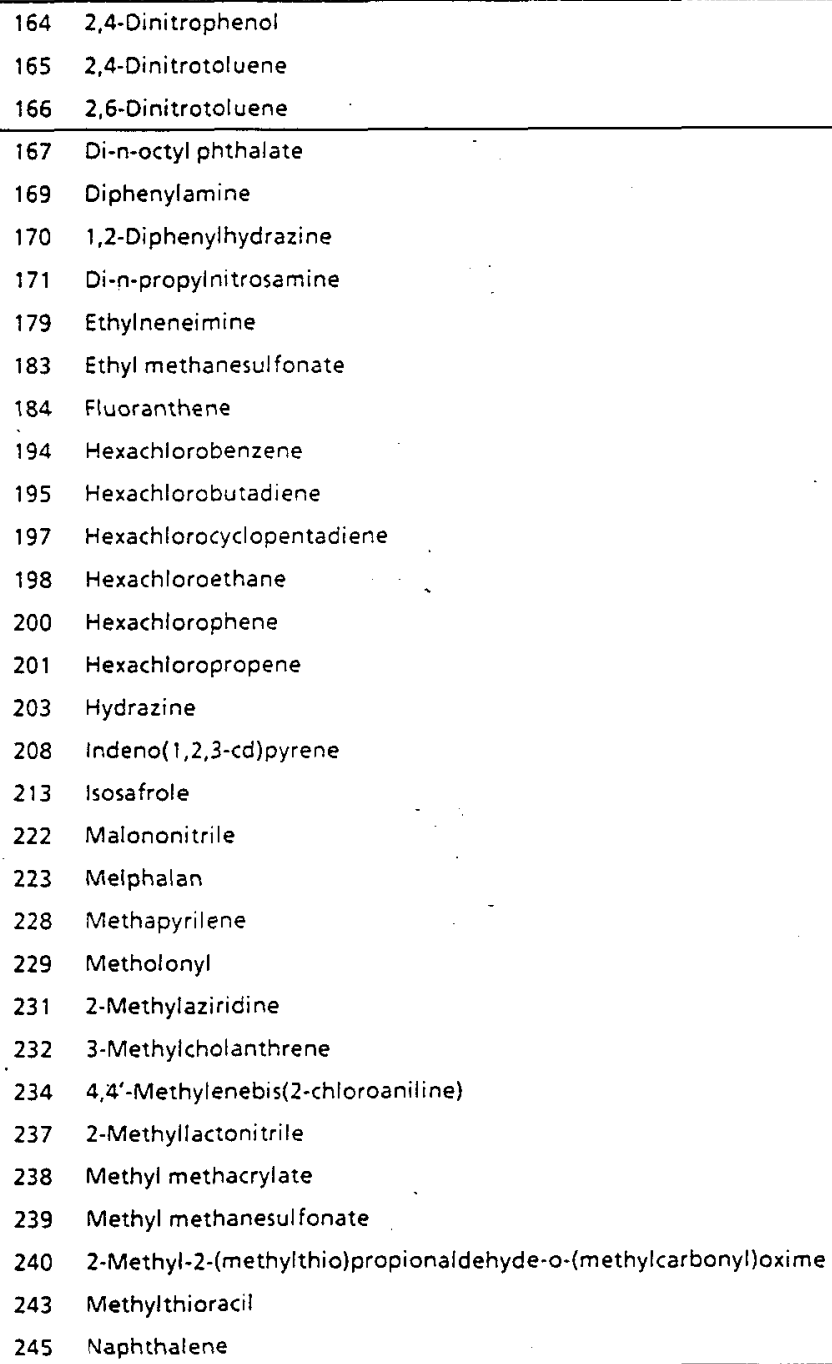


HNF-SD-TWR-TI-005, Rev. 0

Table E-3. Semi-Volatile Organics. (sheet 4 of 5 )

\begin{tabular}{|ll|}
\hline 246 & 1.4 -Naphthoquinone \\
247 & 1 -Naphthylamine \\
248 & 2 -Naphthylamine \\
255 & p-Nitroaniline \\
\hline 256 & Nitrobenzine \\
261 & 4 -Nitrophenol \\
264 & N-Nitrosodi-n-butylamine \\
265 & N-Nitrosodiethanolamine \\
266 & N-Nitrosodiethylamine \\
267 & N-Nitrosodimethylamine \\
269 & N-Nitrosomethylethylamine \\
271 & N-Nitroso-N-methylurethane \\
272 & N-Nitrosomethylvinylamine \\
273 & N-Nitrosomorpholine \\
274 & N-Nitrosonornicotine \\
275 & N-Nitrosopiperidine \\
276 & Nitrosopyrolidine \\
278 & 5-Nitro-o-toluidine \\
284 & Pentachlorobenzene \\
286 & Pentachloronitrobenzene \\
287 & Pentachlorophenol \\
288 & Phenacetin \\
289 & Phenol \\
290 & Phenylenediamine \\
297 & Phthalicacidesters \\
299 & 2 -Picoline \\
303 & Pronamide \\
309 & Reserpine \\
\hline
\end{tabular}

$2198.321 / 2+3$ 
HNF-SD-TWR-TI-005, Rev. 0

Table E-3. Semi-Volatile Organics. (sheet 5 of 5 )

$\begin{array}{ll}324 & 2,3,7,8-T C D D \\ 330 & 2,3,4,6 \text {-Tetrachlorophenol } \\ 346 & \text { Thiuram } \\ 348 & \text { Toluenediamine } \\ 349 & \text { o-Toluidine hydrochloride } \\ 353 & 1,2,4 \text {-Trichlorobenzene } \\ 359 & 2,4,5-\text { Trichlorophenol } \\ 360 & 2,4,6-\text { Trichlorophenol } \\ 365 & \text { 0,0,0-Triethyl phosphorothioate } \\ 366 & \text { sym-Trinitrobenzene } \\ 368 & \text { Tris(2,3-dibromopropyl) phosphate }\end{array}$

(2)13ristidits 
HNF-SD-TWR-TI-005, Rev. 0

Table E-4. Organics by GC/MS Direct

Injection.

\begin{tabular}{|c|l|}
\hline 8 & Acrylamide \\
12 & Allyl alcohol \\
61 & Chioral \\
69 & Chloroacetaldehyde \\
83 & 3-Chloropropionitrile \\
93 & Cyanogen \\
134 & Dichloropropanol \\
176 & Ethyl carbamate \\
177 & Ethyl cyanide \\
180 & Ethylene oxide \\
182 & Ethyl methacrylate \\
187 & Fluoracetic acid \\
190 & Glycidylaldehyde \\
212 & Isobutyl aicohol \\
236 & Methyl hydrazine \\
305 & n-Propylamine \\
307 & 2.Propyn-l-ol \\
\hline
\end{tabular}


HNF-SD-TWR-TI-005, Rev. 0

Table E-5. Constituents That Only Require Analysis for Metal Specis. (sheet 1 of 2)

\begin{tabular}{|rl|}
\hline 19 & Antimony, NOS \\
21 & Arsenic and compounds, NOS \\
23 & Arsenic acid \\
24 & Arsenic pentoxide \\
27 & Barium and compounds, NOS \\
28 & Barium cyanide \\
32 & Benzenearsonic acid \\
42 & Beryllium and compounds, NOS \\
56 & Cadmium and compounds, NOS \\
57 & Calcium chromate \\
84 & Chromium and compounds, NOS \\
88 & Copper cyanide \\
131 & Dichlorophenylarsine \\
139 & Diethylarsine \\
207 & Hydroxydimethylarsine oxide \\
216 & Lead and compounds, NOS \\
217 & Lead acetate \\
218 & Lead phosphate . \\
219 & Leadsubacetate \\
224 & Mercury fulminate \\
225 & Mercury and compounds, NOS \\
250 & Nickel and compounds, NOS \\
251 & Nickel carbonyl \\
252 & Nickel cyanide \\
280 & Osmium tetroxide \\
291 & Phenylmercury acetate \\
302 & Potassium silver cyanide \\
\hline 313 & Selenious acid \\
\end{tabular}

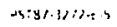


HNF-SD-TWR-TI-005, Rev. 0

Table E-5. Constituents That Only Require Analys is for Metal Specis. (sheet 2 of 2)

\begin{tabular}{|ll}
\hline 315 & Selenium sulfide \\
316 & Selenourea \\
\hline 317 & Silver and compounds, NOS \\
318 & Silver cyanide \\
321 & Strontium sulfide \\
332 & Tetraethyl lead \\
335 & Thallium and compounds, NOS \\
336 & Thallic oxide \\
337 & Thallium acetate \\
338 & Thallium carbonate \\
339 & Thallium chioride \\
340 & Thallium nitrate \\
341 & Thallium selenite \\
342 & Thallium sulfate \\
371 & Vanadic acid, ammonium salt \\
372 & Vanadium pentoxide \\
374 & Zinc cyanide
\end{tabular}

aist-ititi-i 
HNF-SD-TWR-TI-005, Rev. 0

Table E-6. Pesticides/Herbicides.

\begin{tabular}{|ll}
\hline 11 & Aldrin \\
63 & Chlordane \\
73 & Chlorobenzilate \\
100 & DDD \\
101 & DDE \\
102 & DDT \\
130 & $2,4-0$ \\
137 & Dieldrin \\
141 & Carbophenothion \\
149 & Dimethoate \\
172 & Disulfoton \\
174 & Endosulfan \\
175 & Endrin \\
192 & Heptachlor \\
193 & Heptachlor epoxide \\
196 & Lindane andisomers \\
214 & Kepone \\
230 & Methoxychlor \\
242 & Methyl parathion \\
283 & Parathion \\
300 & Polychlorinated biphenyl \\
351 & Toxaphene \\
361 & $2,4,5-T$ \\
362 & $2,4,5-T P$ Silvex \\
\end{tabular}

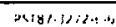


HNF-SD-TWR-TI-005, Rev. 0

Table E-7. Compounds to be Anaiyzed by Class.

\begin{tabular}{|ll|}
\hline TOX: & \\
65 & Chlorinated ethane \\
67 & Chlorinated fluorcarbons \\
68 & Chlorinated phenol \\
118 & Dichlorobenzene \\
125 & Dichloroethylene \\
132 & Dichloropropane \\
135 & Dichloropropene \\
191 & Halomethane \\
\hline 89 & \\
\hline 89 & Creosote \\
\hline 263 & Nitrosamine \\
\hline Ammonium: \\
\hline
\end{tabular}


HNF-SD-TWR-TI-005, Rev. 0

Table E-8. Constituents Unstable in Water.

\begin{tabular}{|cl|}
\hline 5 & Acetyl chloride \\
13 & Aluminum phosphide \\
40 & Benzotrichloride \\
63 & 2-butanone peroxide \\
138 & Carbon oxyfluoride \\
148 & Diisopropylfluorophosphate \\
154 & Dimethylcarbamoyl chloride \\
161 & Dimethyl sulfate \\
185 & Fluorine \\
205 & Hydrofluoric acid \\
211 & Methyl isocyanate \\
220 & Maleic anhydride \\
233 & Methyl chlorocarbonate \\
257 & Nitrogen dioxide \\
293 & Phosgene \\
295 & Phorate \\
296 & Famphur \\
298 & Phthalic anhydride \\
331 & Tetraethyldithiopyroiphosphate \\
350 & Toluene diisocyanate \\
367 & Tris(1-aziridinyl) phosphine sulfide \\
375 & Zincphosphide \\
\hline
\end{tabular}

$\therefore+2: 1212: 5$ 
HNF-SD-TWR-TI-005, Rev. 0

Table E-9. Constituents for Which No Analysis is Available. (sheet 1 of 2)

\begin{tabular}{|c|c|}
\hline 10 & Aflatoxins \\
\hline 15 & Mitomycin C \\
\hline 26 & Azaserine \\
\hline 52 & Brucine \\
\hline 62 & Chlorambucil \\
\hline 96 & Cycasin \\
\hline 98 & Cyclophosphamide \\
\hline 99 & Daunomycin \\
\hline 103 & Diallate \\
\hline 142 & 0,0-diethyiphosphoric acid, 0-p-nitrophenyl ester \\
\hline 144 & Thionazin \\
\hline 147 & $\begin{array}{l}\text { 3,4-dihydroxyu-alpha-(methylamino) methyl benzyl } \\
\text { alcohol }\end{array}$ \\
\hline 173 & 2,4-dithiobiuret \\
\hline 178 & Ethylenebisdithiocarbamic acid \\
\hline 186 & 2-fluoroacetamide \\
\hline 199 & $\begin{array}{l}\text { Hexachlorohyxahydro-endo, endo- } \\
\text { dimethanonaphthalene }\end{array}$ \\
\hline 202 & Hexaethyl thetrphosphyate \\
\hline 210 & Iron dextran \\
\hline 215 & Lasiocarpine \\
\hline 241 & $\mathrm{~N}$-methyl-N'-nitro-N-nitrosoguanidine \\
\hline 244 & Mustard gas \\
\hline 254 & Nitric oxide \\
\hline 258 & Nitrogen mustard $\cdot \mathrm{HCl}$ sait \\
\hline 259 & Nitrogen mustard $\mathrm{N}$-oxide and $\mathrm{HCl}$ salt \\
\hline 260 & Nitroglycerin \\
\hline 262 & 4-nitroquinoline \\
\hline 277 & N-nitrososacrosine \\
\hline 279 & Octamethylpyrophosphoramide \\
\hline 281 & Endothol \\
\hline 282 & Paraldehyde \\
\hline 294 & Phosphine \\
\hline
\end{tabular}

o.r. $1.32+2.8 \cdot 3$ 
HNF-SD-TWR-TI-005, Rev. 0

Table E-9. Constituents for Which No Analysis is Available. (sheet 2 of 2)

\begin{tabular}{|ll}
\hline 304 & 1,3-propanesultone \\
306 & Propylthiouracil \\
311 & Saccharin and salts \\
320 & Streptozotocin \\
333 & Tetraethylpyrophosphate \\
334 & Tetranitromethane \\
343 & Thioacetamide \\
344 & Thiosemicarbazide \\
369 & Trypan blue \\
370 & Uracil mustard
\end{tabular}

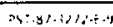


HNF-SD-TWR-TI-005, ReV. 0

Table E-10. Miscellaneous

Organics and Inorganics.

\begin{tabular}{|cl|}
\hline 86 & Citrus red No. 2 \\
\hline 92 & Cyanide \\
\hline 204 & Calcium cyanide \\
\hline 301 & Potassium cyanide \\
\hline 319 & Sodium cyanide \\
\hline 94 & Cyanogen bromide \\
\hline 95 & Cyanogen chloride \\
\hline 188 & Formaldehyde \\
\hline 189 & Formic acid \\
\hline 221 & Maleichydrazide \\
\hline 253 & Nicotine and salts \\
\hline 322 & Strychnine \\
\hline 345 & Thiourea \\
\hline 6 & 1-Acetyl-2-thiourea \\
\hline 82 & 1-(o-Chlorophenyl)thiourea \\
\hline 145 & Diethylstilbesterol \\
\hline 181 & Ethylenethiourea \\
\hline 249 & 1-Naphthyl-2-thiourea \\
\hline 268 & N-Nitroso-N-ethylurea \\
\hline 270 & N-Nitroso-N-methylurea \\
\hline 292 & N-Phenylthiorea \\
\hline
\end{tabular}

a.5 1.121 .2 .15 
HNF-SD-TWR-TI-005, Rev. 0

APPENDIX C

LETTER REPORT ON RADIOLOGICAL SURVEY OF SEDIMENTS

IN 216-A-29 DITCH

C-1 
$H(-5)-11 \times-\ldots-40,804$

\section{Internal Letter}

Date. January 12, 1983

TO: (Nyme Organization. Internal Aitcies:s)

J. D. Galbraith

-Capital Projects

.2750-E/0-225/200 East Area
Rockwell International

iso .72710-83-006

FROM: iNane. O.ganization. intemsi cooress, Prones

.K. R. Fecht

- Environmental Technologies M0-936/200 West Area $.3-2971$

Subjec: .Radiological Survey of Sediments in the 216-A-29 Ditch

A radiological survey was conducted by the Environmental Technologies Group in the upper portion of the 216-A-29 Ditch. The purpose of the survey was to estimate the amount of contaminated or potentially contaminated sediments beneath the ditch that will be required to be removed prior to general construction activities in the proposed 241-AP Tank Farm. The results of the radiological survey and a conservative estimate of the amount of soil that needs to be removed are presented.

Sediment samples were collected for analys is from 5 shallow core borings in the ditch bottom and from 8 auger borings along the ditch banks. The borings were drilled on 5 transects across the ditch (Figure 1). The shallow core borings were hand cored to a depth of 3 to 4 feet and the 8 auger borings were drilled to a depth of about 12 feet. Sediments retrieved from the borings were surveyed by Radiation Monitoring Group personnel using portable field instruments and no detectable contamination was observed.

The sediments were sampled from the top, middle and bottom of each boring except for shallow core boring $\#$ t. Selected sediment samples were analyzed for the following radionuclides using the Mobile Radionuclide Analys is Laboratory (MRAL) I; $40 \mathrm{~K}, 60 \mathrm{Co}, 137 \mathrm{Cs}, 152 \mathrm{Eu}, 228 \mathrm{Th}, 88 \mathrm{Y}, 24 \mathrm{Am}$, and $239 \mathrm{Pu}$. Al] radionuclide concentrations using MRAL I were comparable to background levels except for ${ }^{137} \mathrm{Cs}$. The concentration of ${ }^{137} \mathrm{Cs}$ in the shallow core borings, particularly the top sample from the shallow core borings, is consistently higher than background levels. Incorporation of corrections for moisture which is estimated to range from 20 to 30 percent in the shallow core samples from the ditch bottom, will give a maximum observed value of $90 \mathrm{pCi} / \mathrm{g}$ in the top sample from shallow core boring $\# 2$. This highest observed value is a fraction of the acceptable limit of $400 \mathrm{pCi} / \mathrm{g}$ set in RHO-MA-139.

Based on the results of the analyses from MRAL. I no radionuclide concentrations were detected at or in excess of soil standards set in RHO-MA-139. The highest concentrations of $137 \mathrm{Cs}$ were found in the mud in the ditch bottom. The mud layer which consists of organic material and fine-grained sediments is about 6 - to 9 -inches thick. The ${ }^{137} \mathrm{Cs}$ values generaliy decreased with depth in the borings. Based on this data $j t$ is recommended that the upper 18 inches of the ditch bottom out to 3 feet beyond the shorelines on the ditch banks and the upper 18 inches of the ditch banks be considered contaminated sediments. These sediments then must be removed and disposed to an approved site for $10 \mathrm{w}-1$ evel radioactive materials. 


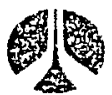

J. D. Galbraith

Page 2

January 12, 1983

If you have any questions regarding this survey, please contact me.

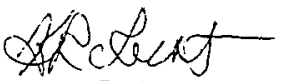

K. R. Fecht, Staff Geologist

Environmental Technologies Group

KRF/lkd

Att.

cC: M. J. Graham

H. A. Haerer

W. F. Heine

W. P. Kunkel

R. M. Mitcheli

V. B. Subrahmanyam 

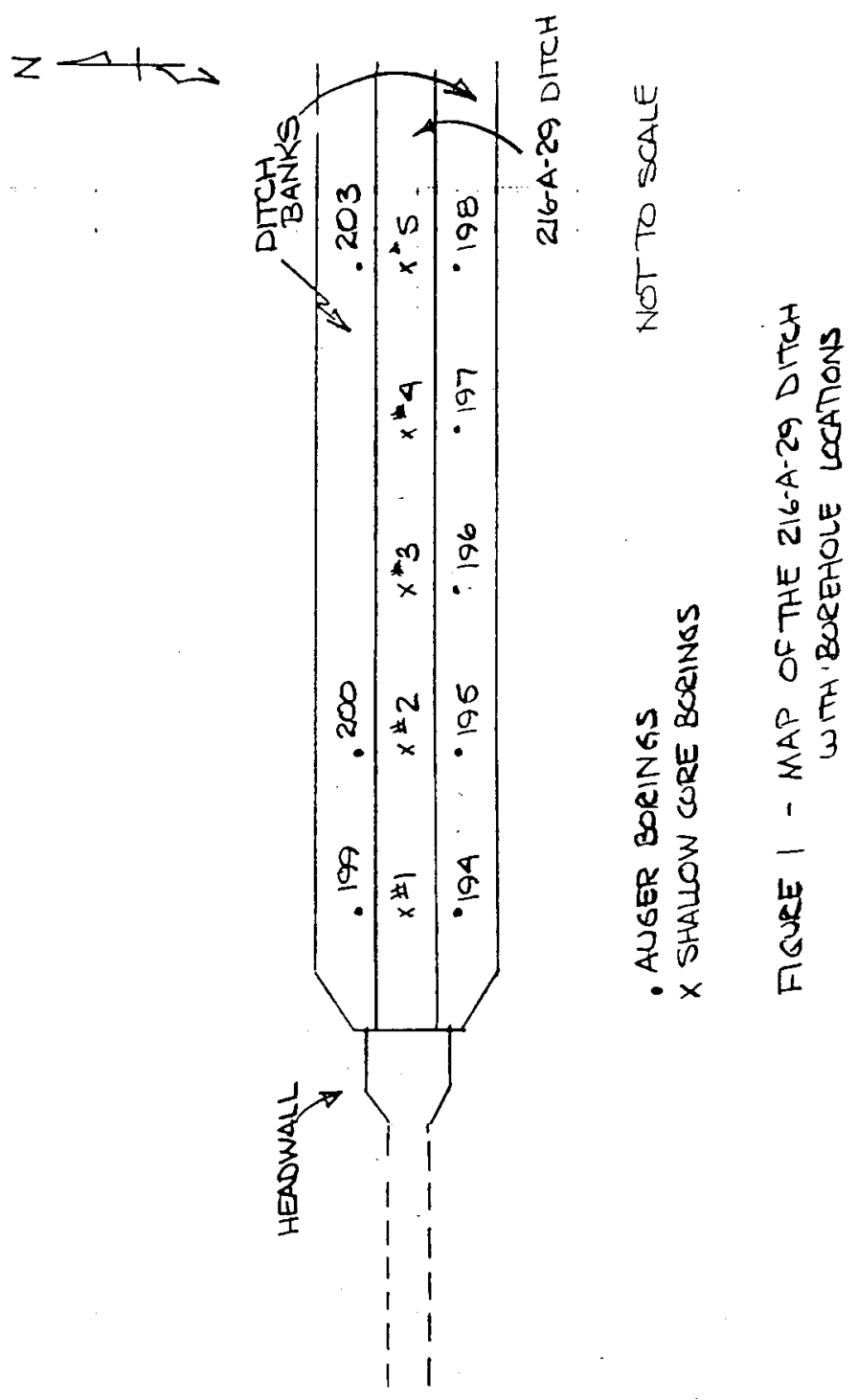
HNF-SD-TWR-TI-005, Rev. 0

\section{APPENDIX D}

\section{A-29 DITCH FIELD LOGBOOK}

D-1 
PROJECT_A-29 Jirk

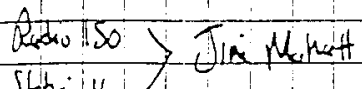

Sthail16

(lotera $5 / 24109$

Wind SSE a +8i-10 mh

$\tan 268^{\circ} \mathrm{F}$

Sunty wame theids forfety Meetivy : 0930

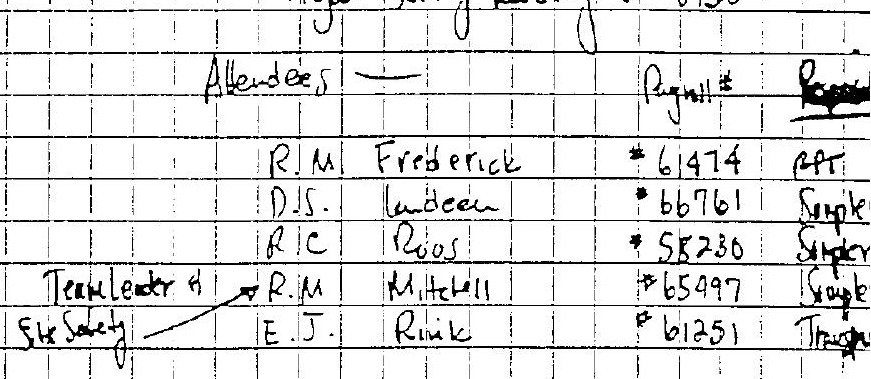

Hule Radig Bakgroud - $<0.5 \mathrm{ppm}$ at 1040

Hou Read bimple polled-30.5 ppm at 1040

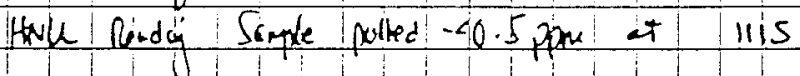

Hover Rind Sample pulkd <0.5ppm at ! 1150

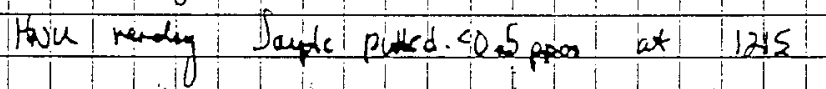

Unitrita - for cenples

Cosith II singte ret' of atios

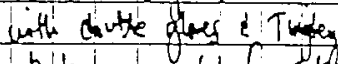
butk - I wited fo Soloth ready fri yodrzike

Spesal! Jutrutin:

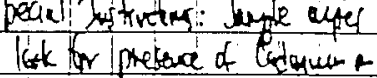
sefecter suspes

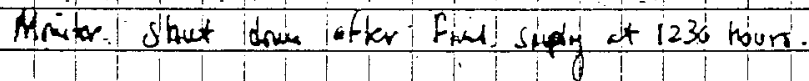

The fust set of soll ind sedinent samples were collected frou the voper and of the

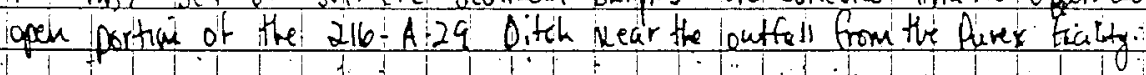

Sainde Site 1

Senple sife I way llocuted directy in the A-29 Dith at a punt 191 feet

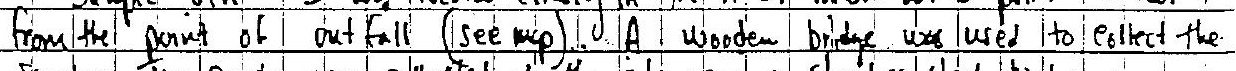

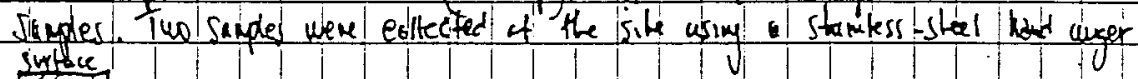

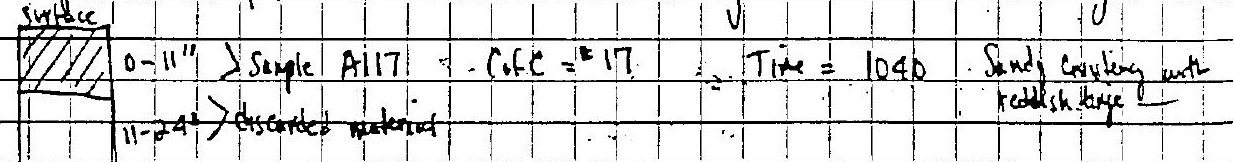

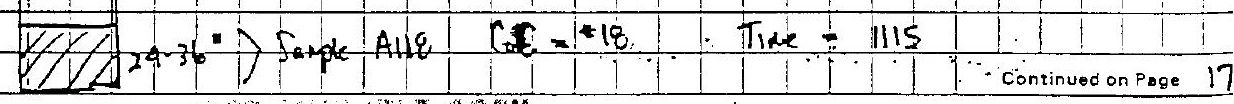

Rm Noteres

$564 / 88$

Read and Understood By

Date D-2

signed $\div 25$

1 Toune 
ECT_P-29 Pith HNF-SD-TWR-TI-005, Rev. O

16

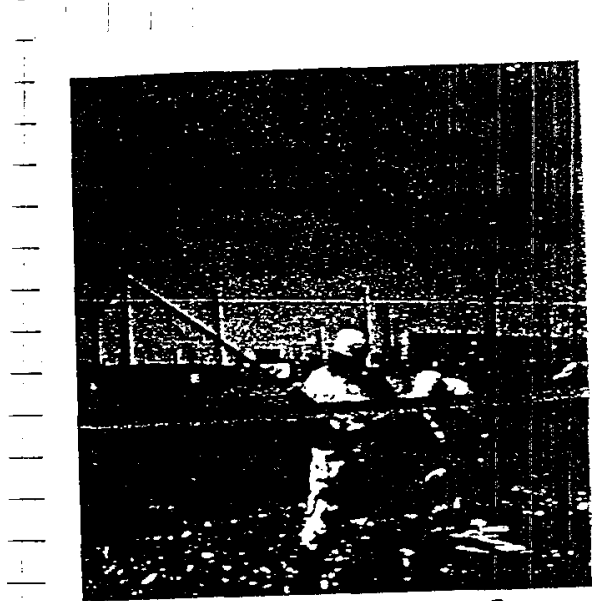

- A.2P Ditch Sample from

- staples site 1

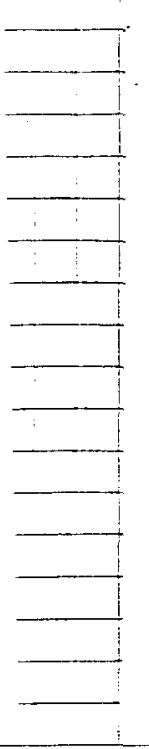

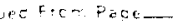

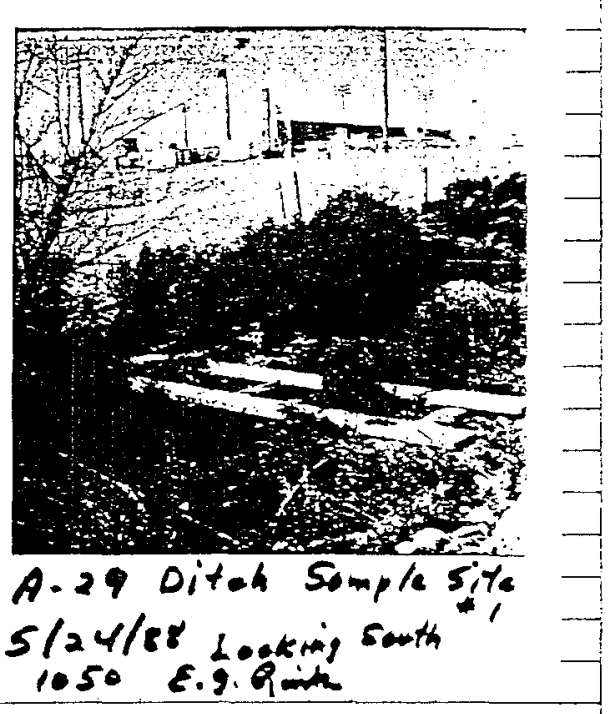

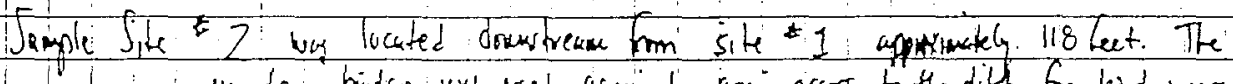
wooden bridge use lased again to fila acer to the ditch for had-bugery

Surface

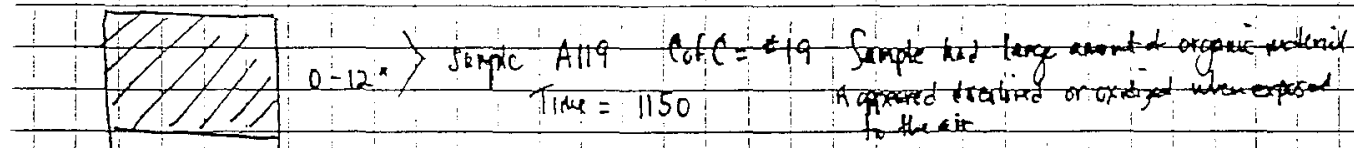

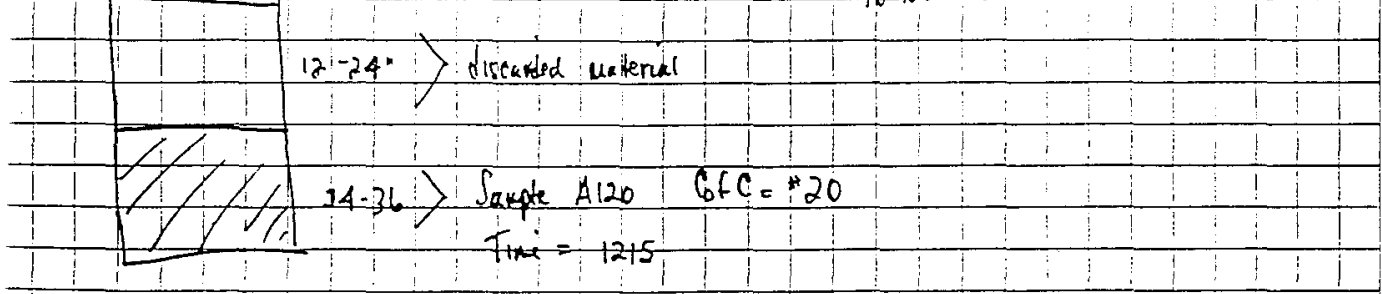

Saiph ins closed out at app or. 1310 Continued on Page 18

In notches

Read and Understood $B Y$

signed

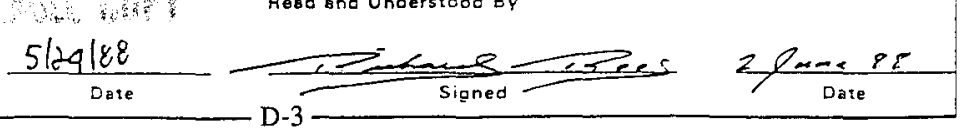



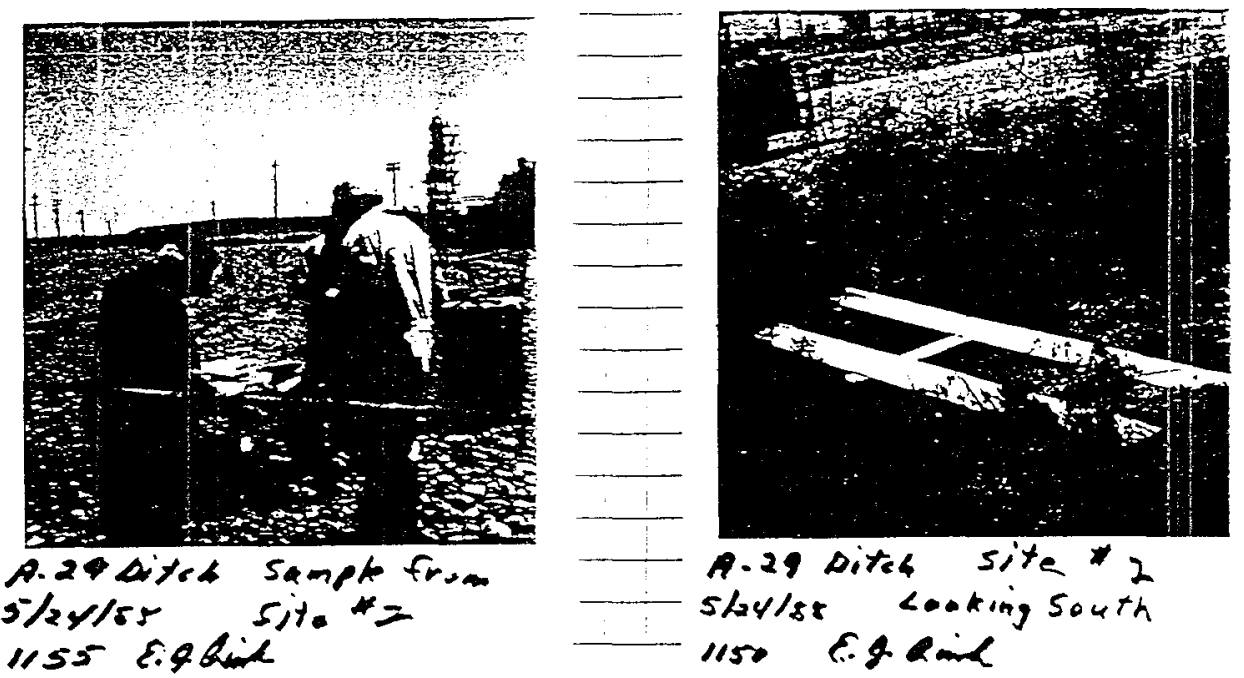

Atter condeter of the semph of the head-and if the ditch it use upcosay fo exit

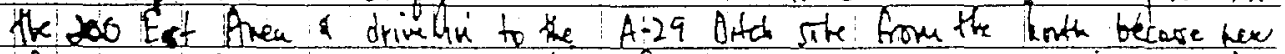

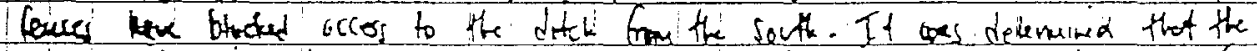

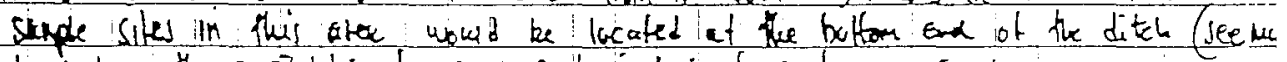

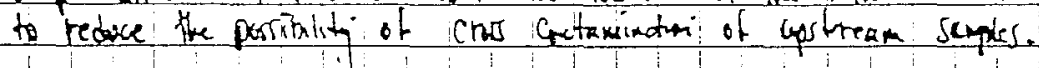

lek $=5258$

Leatter: Plear teeris $27.9 \%$

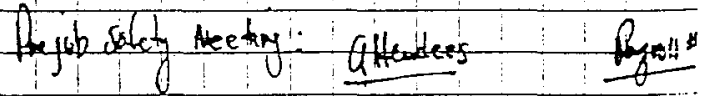
hand: $=0-3$ mph

\begin{tabular}{|c|c|c|}
\hline M Nutcka & & 65497 \\
\hline E.J.Rik & 1 & 61251 \\
\hline D.F helsm & & $6205^{\circ}$ \\
\hline R M Trederick & (RPT) & 1614 \\
\hline 0.1. Tundeen & & 6676 \\
\hline R.C Rिos & & \\
\hline
\end{tabular}

Continued on Page 14

dy

512588 Rmpletar 


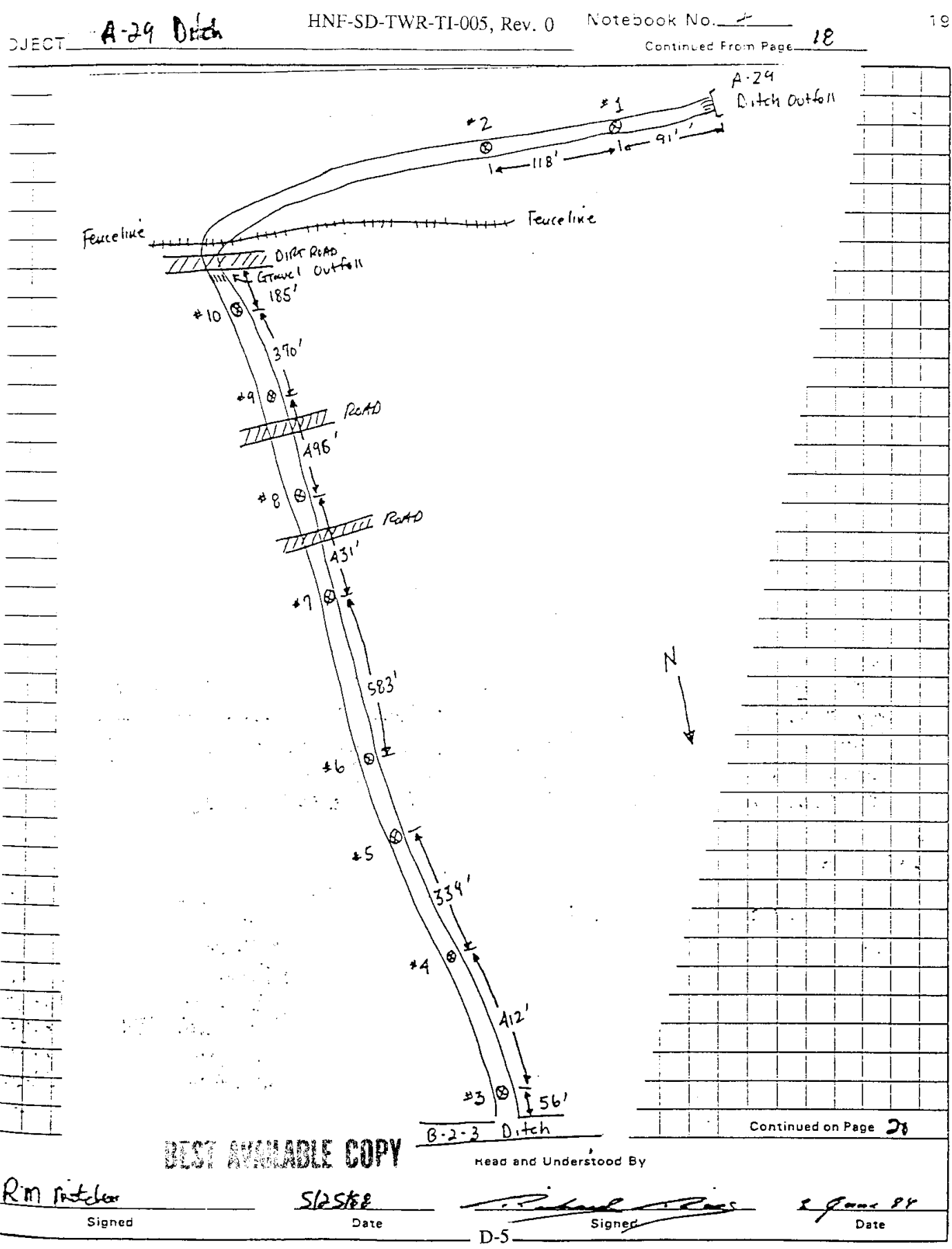


20
PROJECT_A.24 Detch

Coritived From Faoc. 19

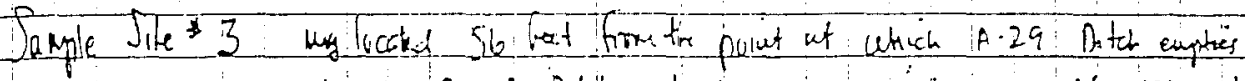

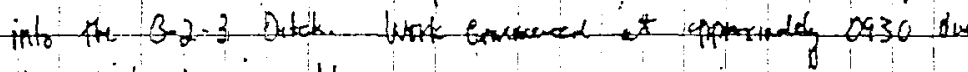

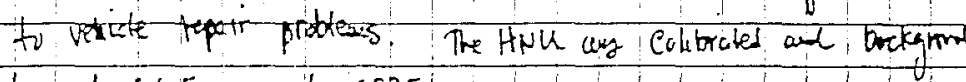
wo decrumed to be $4<0.5$ ppm at 0935 .

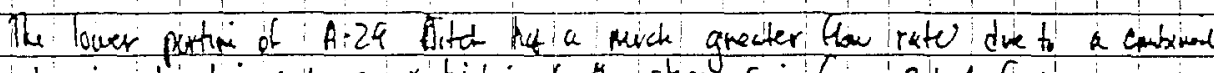

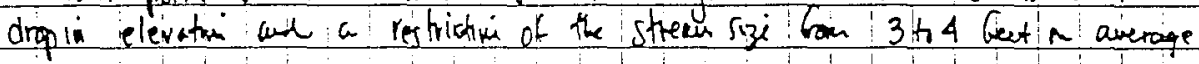

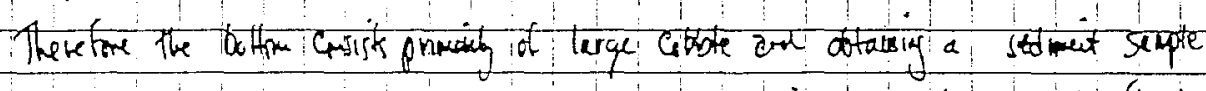

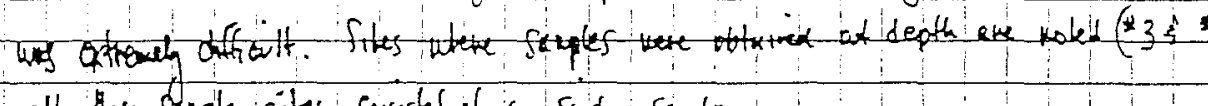
all other somple sites cassest of a singe senple.

Jirtace

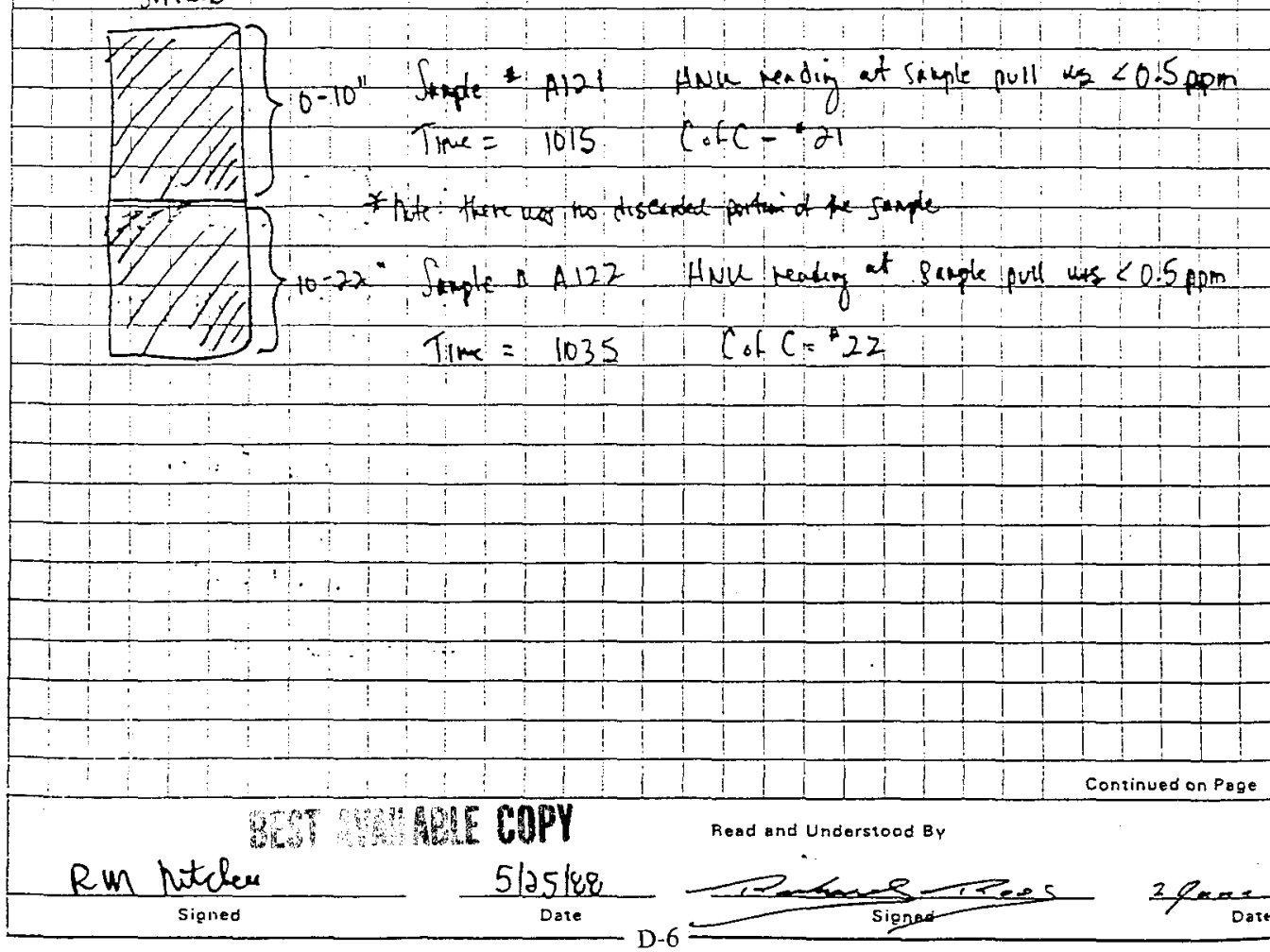




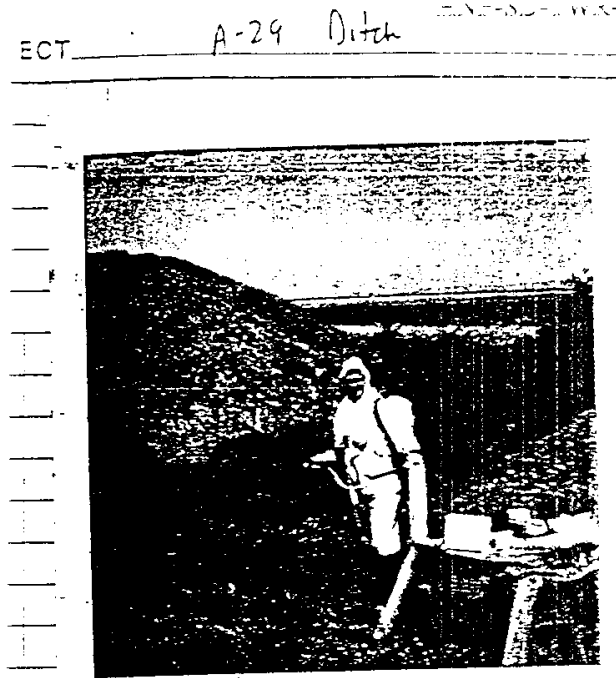

- A-29 Dikeh Sit 3

I 5lastos Rm Nteleur

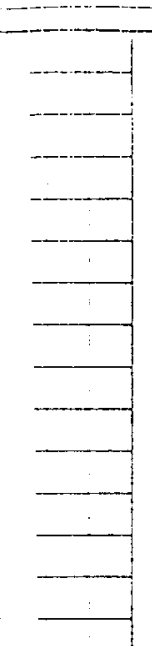

$$
\text { A }
$$

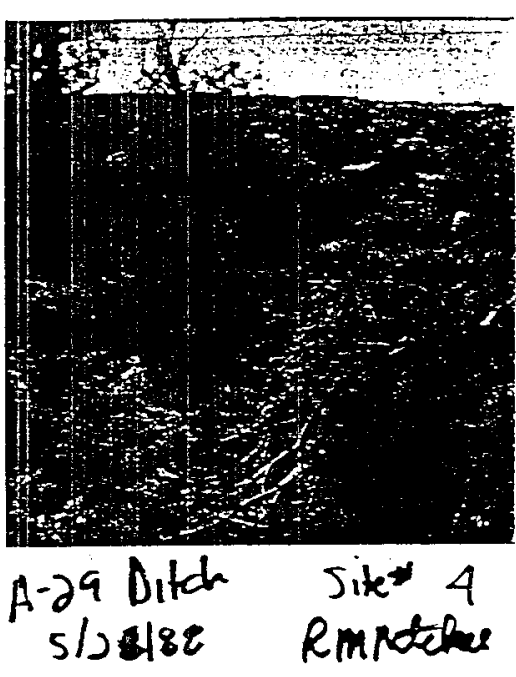

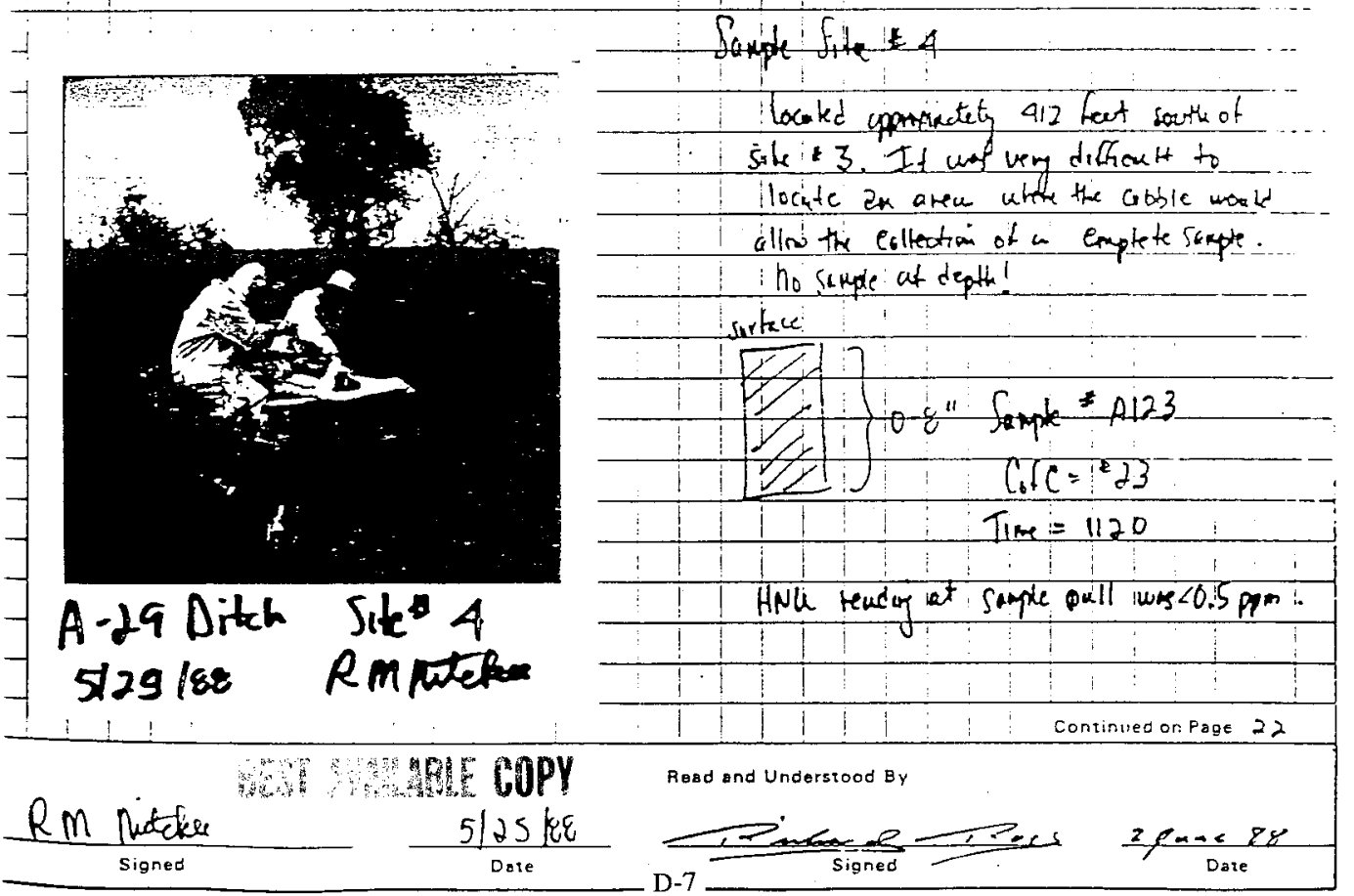




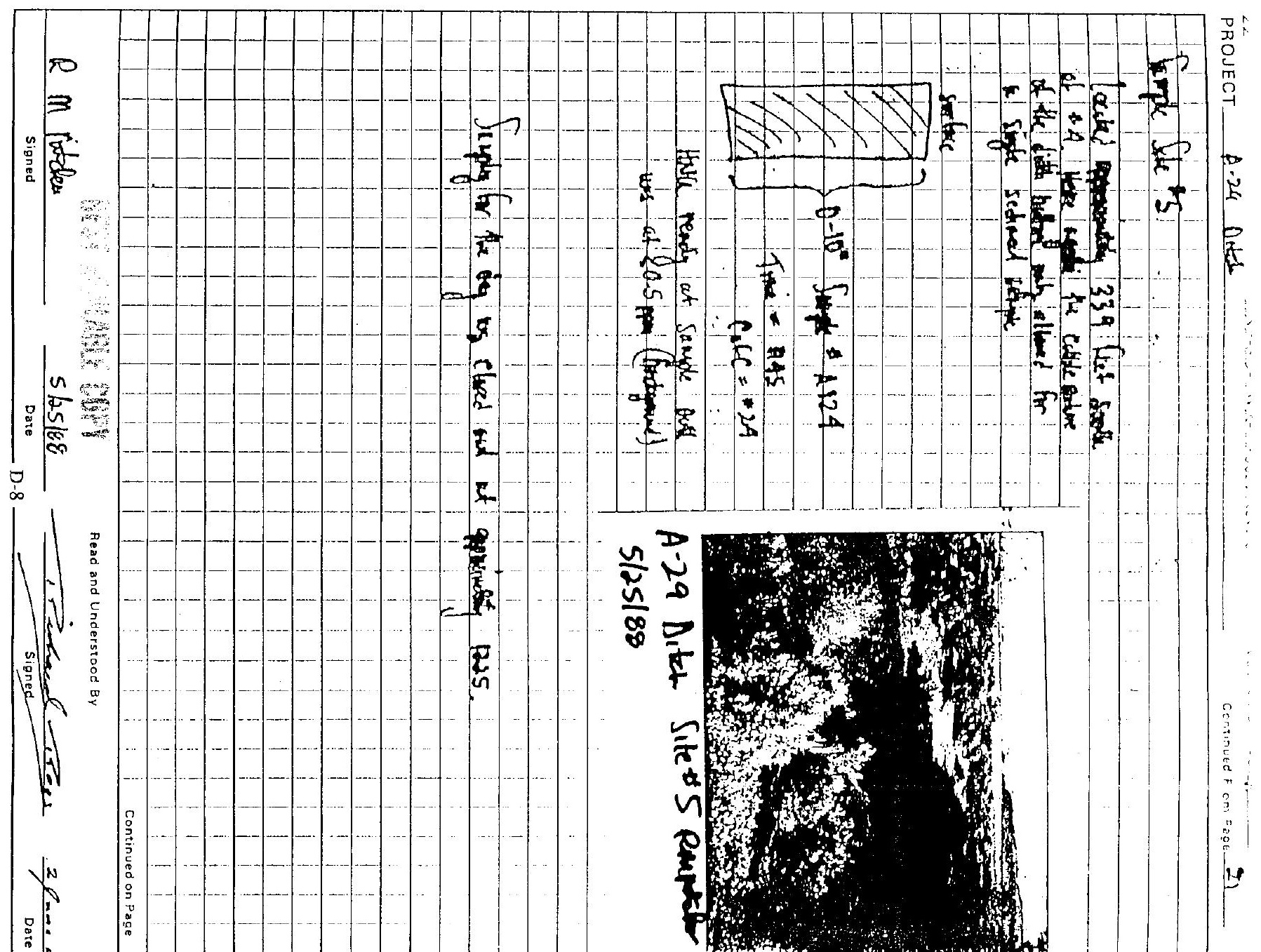




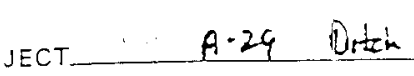

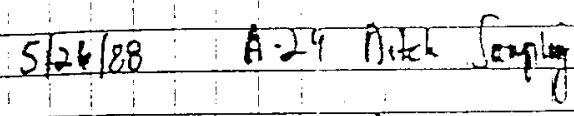

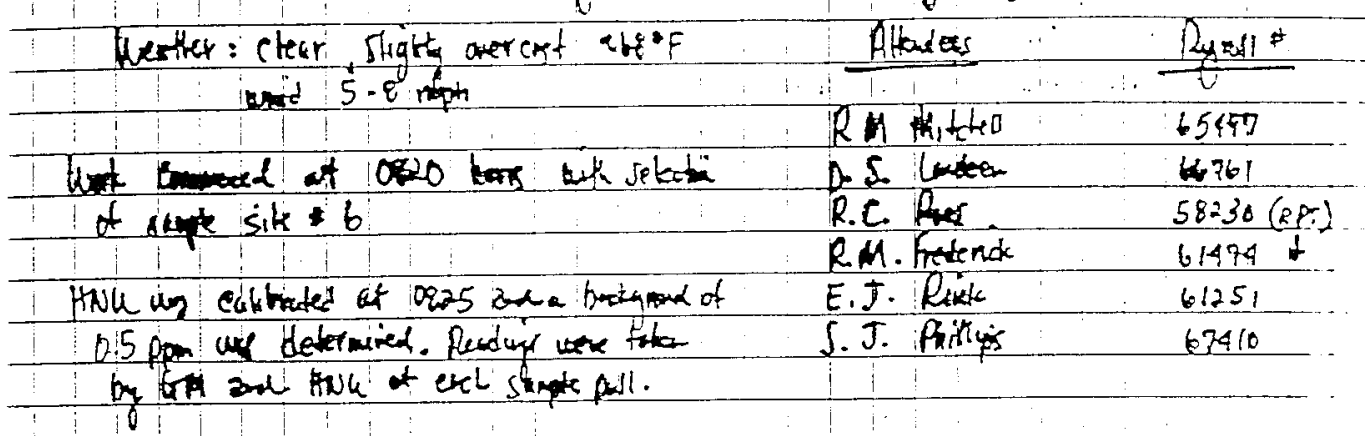

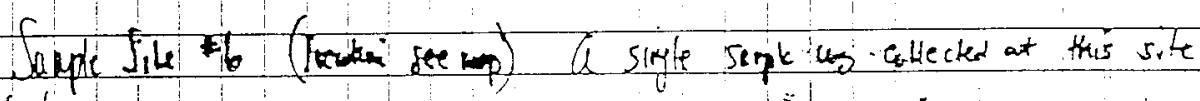

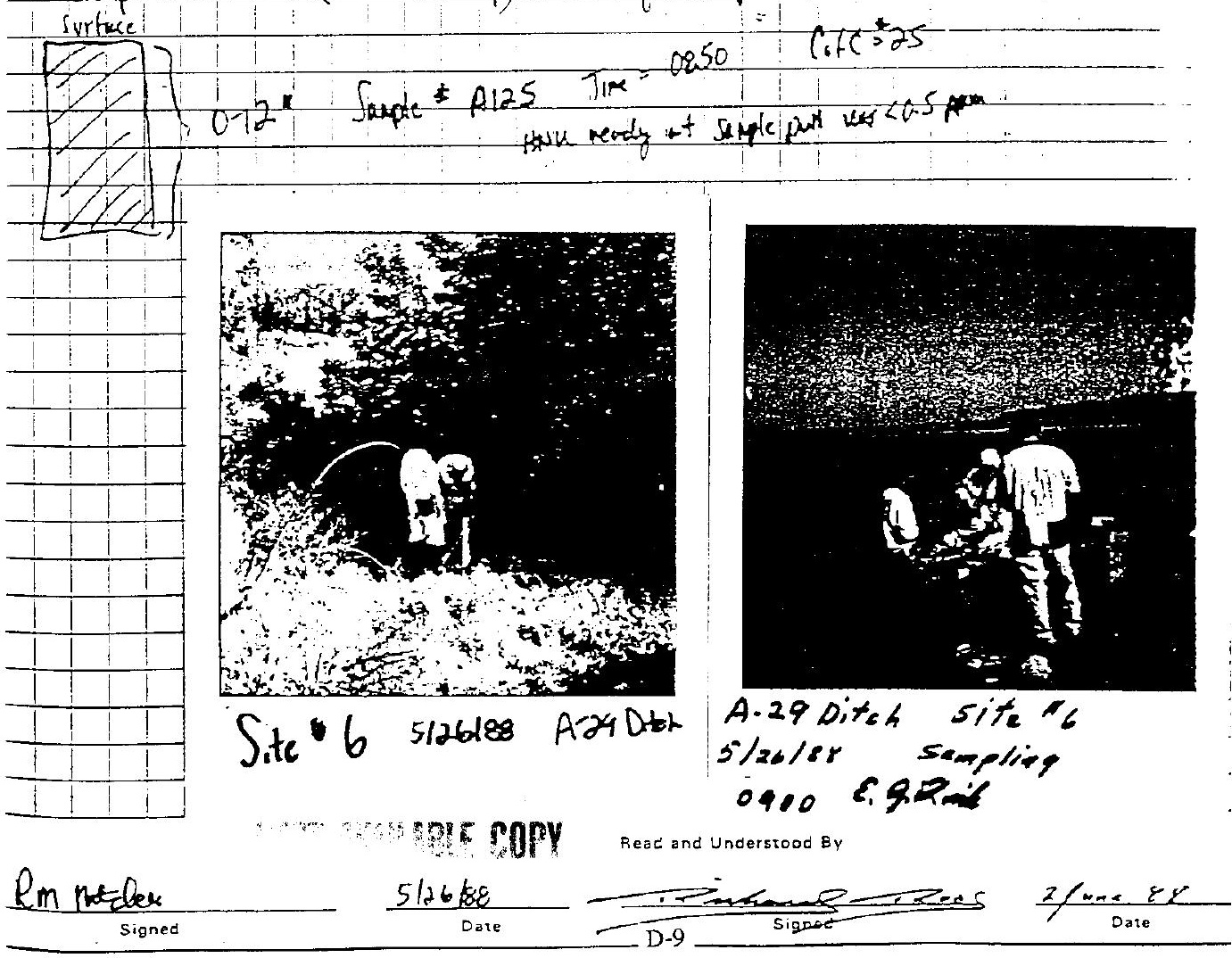




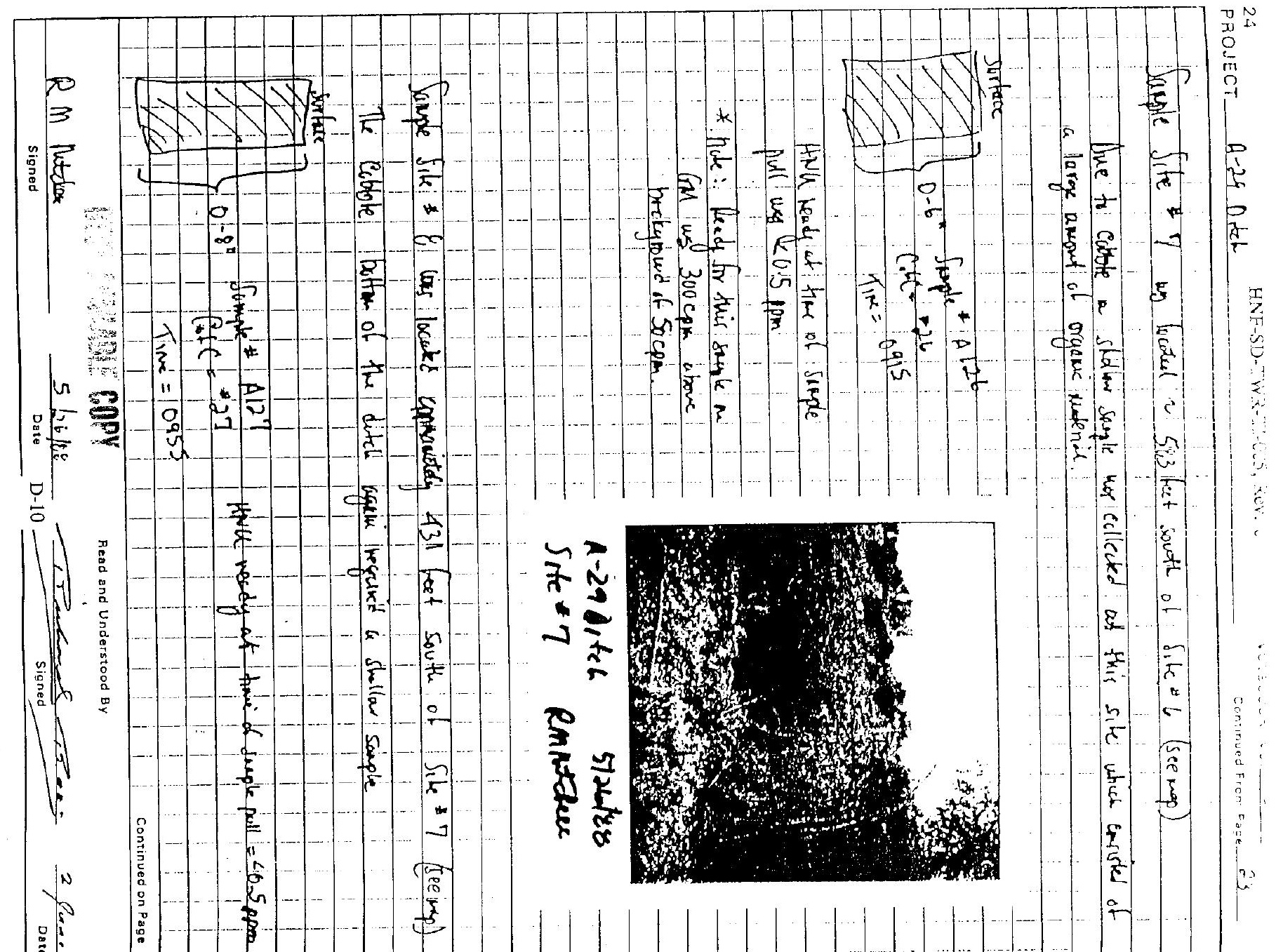




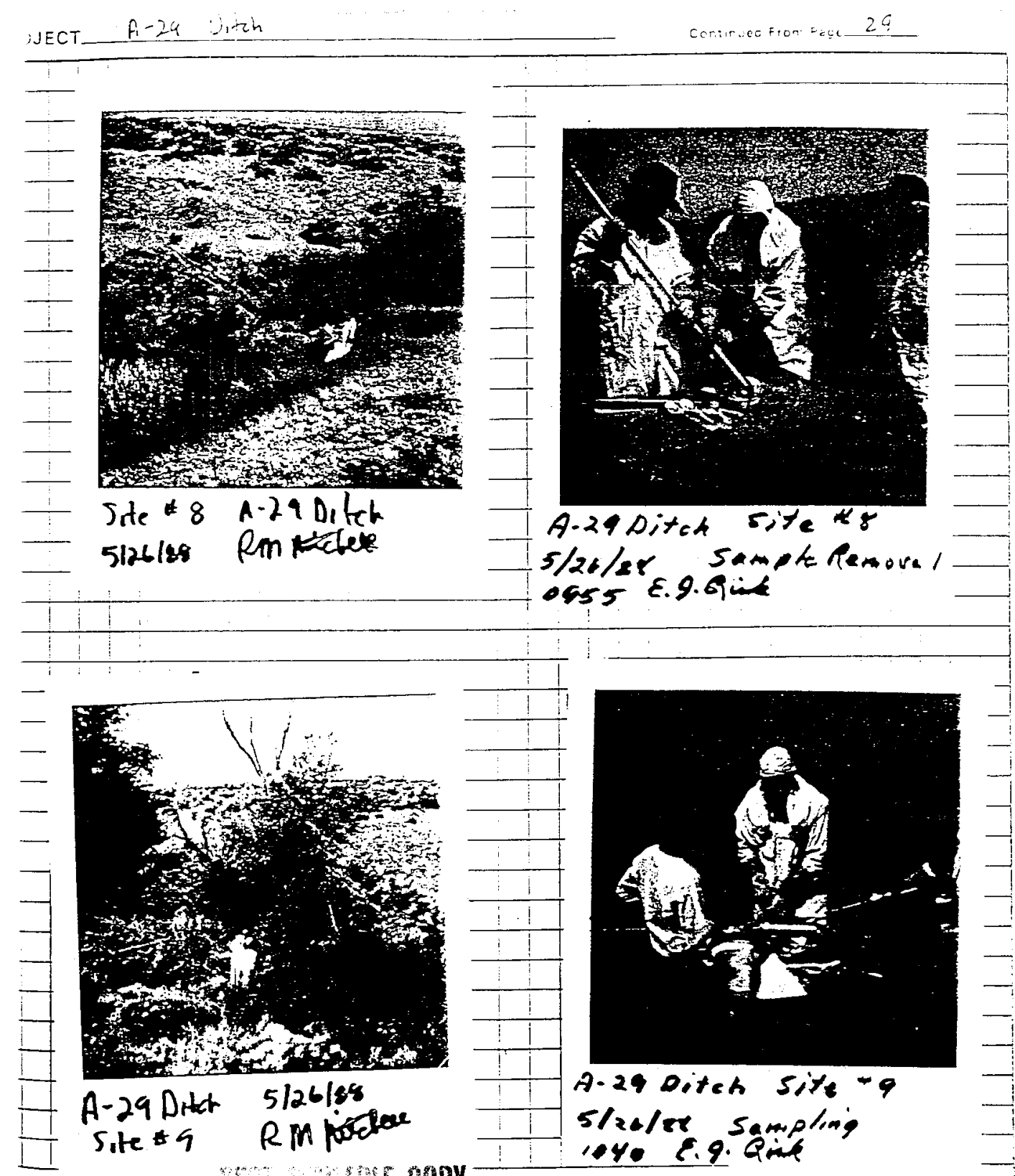


25
PROJECT_A.2G Ditch EN-SO-TWR-TI-005, Rev. 0

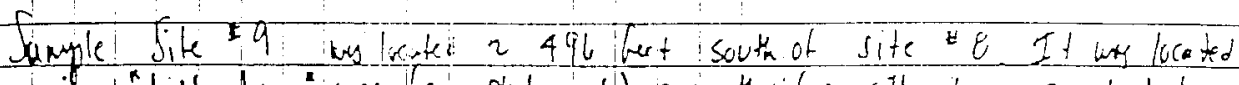

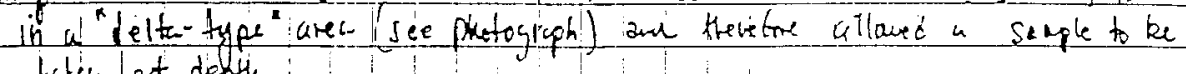
tiken lat depth.

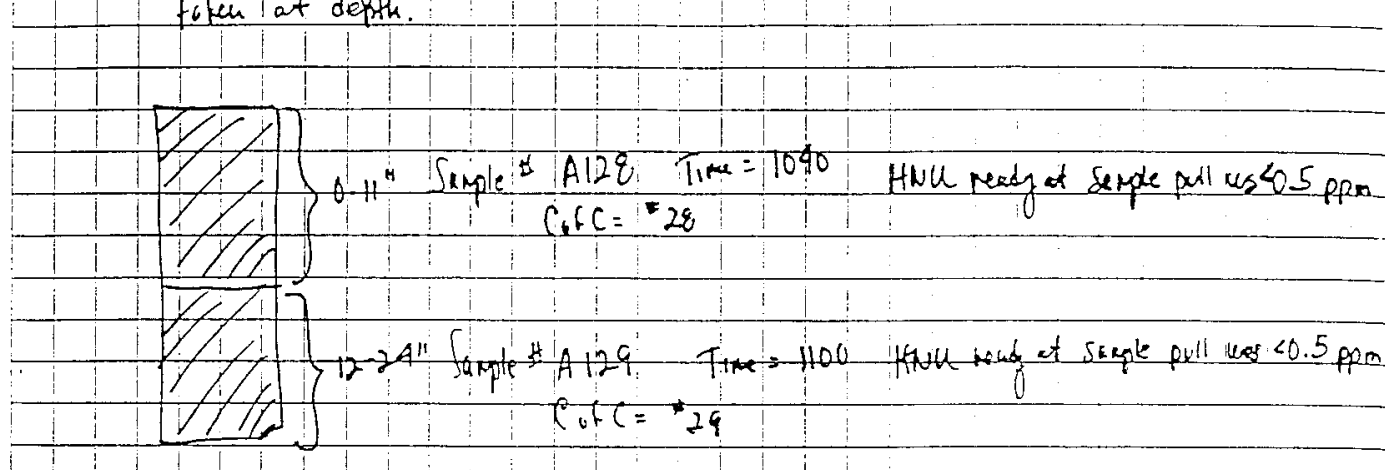

Salpe file 10 bas locekd e 185 bet

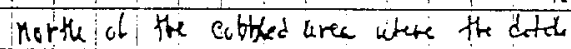

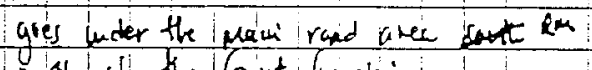

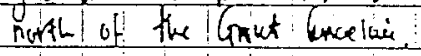

Ut simgl semple us Celleded at therite

sunfoce

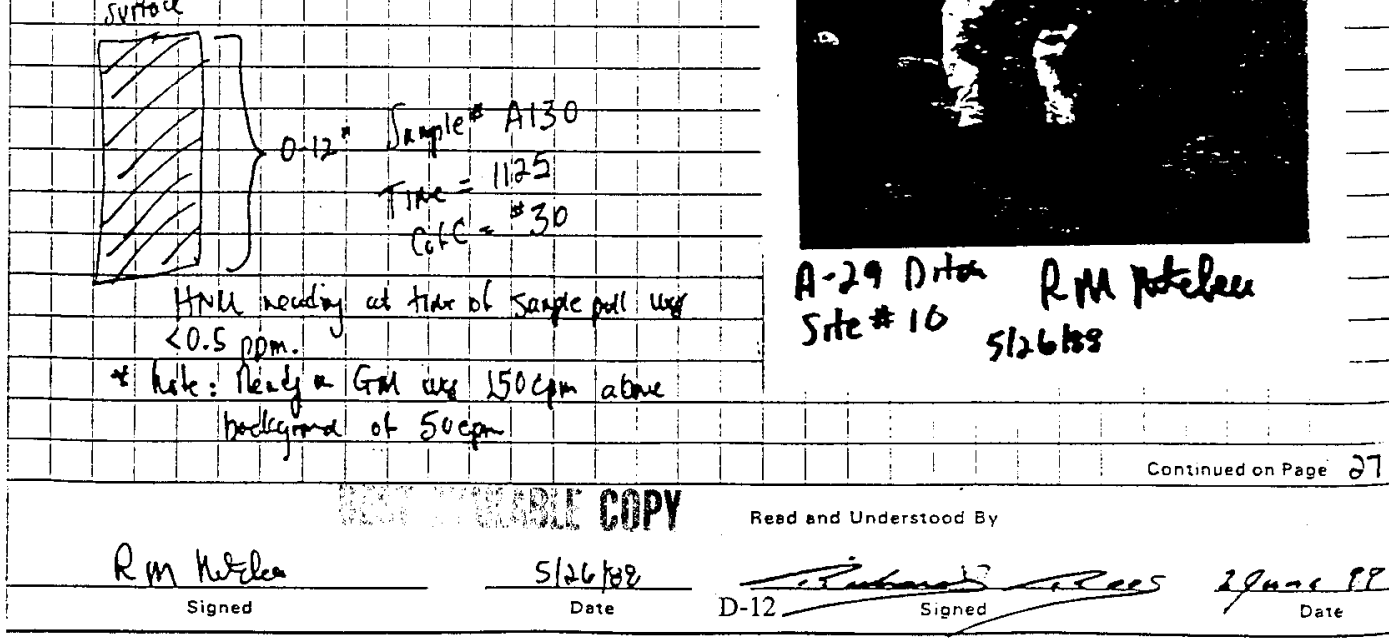




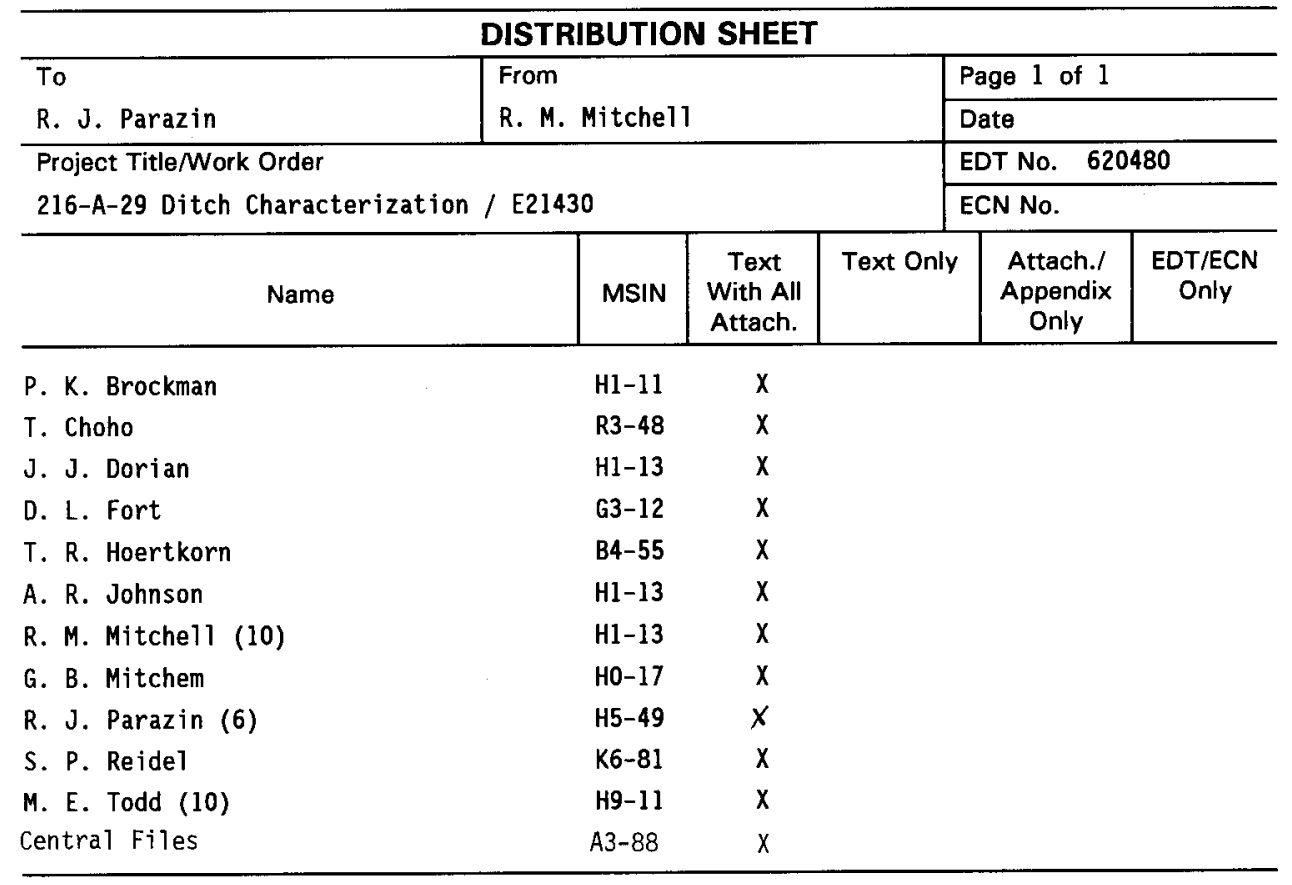

